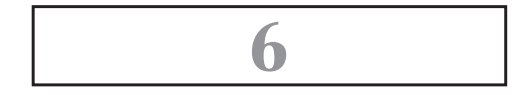

\title{
PERFIL DAS TRANSFERÊNCIAS VOLUNTÁRIAS
}

A importância das transferências voluntárias nem sempre se reflete nas estatísticas que retratam sua participação na formação da receita dos entes federados. No entanto, representam um relevante instrumento para que as unidades da federação possam efetuar investimentos e impulsionar seu efetivo desenvolvimento, tendo em vista que os recursos próprios, somados às transferências obrigatórias, especialmente na esfera municipal, são revertidos em grande parte para as despesas correntes - e, mesmo assim, de forma insuficiente. A esse propósito, pontua Márcia Miranda Soares:

É fato que as receitas de TVU não representam a principal fonte de recursos dos $\mathrm{Mu}$ nicípios, o que é positivo no sentido de garantir autonomia e regularidade fiscal aos entes locais na implementação de políticas públicas. Contudo, as transferências voluntárias não são desprezíveis, superam a arrecadação própria, e são atrativas aos $\mathrm{Mu}$ nicípios porque permitem aumentar sua capacidade de implementar políticas públicas, principalmente as de investimentos, em um contexto marcado por rigidez orçamentária, dados os gastos com pessoal, consumo governamental, despesas financeiras e alta vinculação de receitas a gastos sociais. Também é uma importante fonte de poder para o Executivo nacional, seja nas suas relaçōes com o Legislativo nacional, seja nas suas relações com os governos e cidadãos subnacionais (...). ${ }^{1}$

Em consequência, a relevância das transferências voluntárias não deve ser mensurada unicamente quanto aos valores absolutos de transferências de recursos, mas sim em termos de sua efetiva participação nos investimentos voltados ao

1 SOARES, Márcia Miranda. Repasses Financeiros e Voluntários da União aos Municípios Brasileiros: condicionantes políticos, sociais e técnicos. In: $8^{\circ}$ ENCONTRO DA ABCP. Anais do $8^{\circ}$ Encontro da ABCP. Gramado, 2012, p. 13. 
desenvolvimento e à melhoria das condições de vida da população dos entes beneficiados. Isso é verdadeiro especialmente para parcela dos Municípios brasileiros, que não dispõem de recursos próprios nem mesmo para a consecução de despesas ordinárias relacionadas ao financiamento do mínimo existencial dos cidadãos.

\subsection{CONSTATAÇÕES ESTATÍSTICAS FORMADORAS DO PERFIL}

Embora os dados relacionados às transferências voluntárias propriamente ditas não sejam disponibilizados em sua mais ampla clareza e transparência, algumas conclusões podem ser alcançadas com base na análise das informaçôes atualmente disponíveis. Elas permitem algumas constatações acerca do perfil dessas operações no federalismo brasileiro, apresentadas sem pretensão de aprofundamento estatístico, mas apenas com o intuito de estabelecer bases para a delineação de um quadro geral da matéria. Com esse objetivo, são pontuadas algumas considerações formuladas em razão dos números envolvidos nessas transferências, relacionadas especialmente às regiốes mais favorecidas - aí incluídos os estados e Municípios -, bem como à relação entre o volume de recursos e a natureza do ente federativo.

\subsubsection{Regiões mais favorecidas}

A Região Nordeste é aquela que concentra o maior volume de recursos repassados por meio de transferências voluntárias, em termos absolutos. Tomando-se como exemplo o exercício de 2013, observa-se que a Região Nordeste ocupa a primeira colocação, seguida pelas Regiões Sudeste, Sul, Norte e Centro-Oeste.

Tabela 6.1 Volume de transferências voluntárias da União, por região do país, em 2013

\begin{tabular}{|c|c|}
\hline REGIÃO & VOLUME DE REPASSE \\
\hline Nordeste & $\mathrm{R} \$ 4.041 .513 .040,00$ \\
\hline Sudeste & $\mathrm{R} \$ 3.223 .670 .384,00$ \\
\hline Sul & $\mathrm{R} \$ 1.852 .891 .178,00$ \\
\hline Norte & $\mathrm{R} \$ 1.690 .695 .506,00$ \\
\hline Centro-Oeste & $\mathrm{R} \$ 1.172 .317 .645,00$ \\
\hline
\end{tabular}

Fonte: elaboração própria a partir de BRASIL. Ministério do Planejamento, Orçamento e Gestão, Secretaria de Logística e Tecnologia da Informação - SLTI, cit., p. 126.

Contudo, quando considerada a quantidade de ajustes celebrados, a região Sul é a que apresentou o maior número de transferências: 
Tabela 6.2 Quantidade de ajustes celebrados para transferências voluntárias da União, por região do país, em 2013

\begin{tabular}{|c|c|}
\hline REGIÃO & QUANTIDADE DE TRANSFERÊNCIAS \\
\hline Sul & 3.298 \\
\hline Nordeste & 2.996 \\
\hline Sudeste & 2.779 \\
\hline Norte & 1.370 \\
\hline Centro-Oeste & 987 \\
\hline
\end{tabular}

Fonte: elaboração própria a partir de BRASIL. Ministério do Planejamento, Orçamento e Gestão, Secretaria de Logística e Tecnologia da Informação - SLTI, cit., p. 126.

$\mathrm{Na}$ relação estabelecida entre os Estados e a União, no exercício de 2013 o Estado da Bahia foi aquele que obteve o maior volume de recursos objeto de execução financeira das transferências voluntárias, conforme aponta o quadro a seguir:

Tabela 6.3 Volume de transferências voluntárias da União, por Estado, em 2013

\begin{tabular}{|c|c|}
\hline ESTADO & $\begin{array}{c}\text { VOLUME DE RECURSOS OBJETO DE EXECUÇÃo } \\
\text { FINANCEIRA }\end{array}$ \\
\hline Bahia & $\mathrm{R} \$ 295$ milhões \\
\hline Rio Grande do Sul & $\mathrm{R} \$ 283,8$ milhões \\
\hline São Paulo & $\mathrm{R} \$ 264,7$ milhões \\
\hline Pernambuco & $\mathrm{R} \$ 261,3$ milhões \\
\hline Rio de Janeiro & $\mathrm{R} \$ 260,2$ milhões \\
\hline Minas Gerais & $\mathrm{R} \$ 255,5$ milhões \\
\hline Paraná & $\mathrm{R} \$ 175,5$ milhões \\
\hline Ceará & $\mathrm{R} \$ 168,8$ milhões \\
\hline Goiás & $\mathrm{R} \$ 99,5$ milhões \\
\hline Santa Catarina & $\mathrm{R} \$ 97,5$ milhões \\
\hline
\end{tabular}

Fonte: elaboração própria a partir de BRASIL. Ministério do Planejamento, Orçamento e Gestão, Secretaria de Logística e Tecnologia da Informação - SLTI, cit., p. 126.

No tocante aos Municípios, a Região Nordeste também lidera a lista, encabeçada pelo Município de Recife, seguido de Salvador: 
Tabela 6.4 Volume de transferências voluntárias da União, por Município, em 2013

\begin{tabular}{|c|c|}
\hline MUNICíPIO & $\begin{array}{c}\text { VOLUME DE RECURSOS OBJETO DE EXECUÇÃo } \\
\text { FINANCEIRA NO EXERCícIO }\end{array}$ \\
\hline Recife & $\mathrm{R} \$ 251,7$ milhões \\
\hline Salvador & $\mathrm{R} \$ 239,6$ milhões \\
\hline Rio de Janeiro & $\mathrm{R} \$ 215,6$ milhões \\
\hline Porto Alegre & $\mathrm{R} \$ 178,0$ milhões \\
\hline São Paulo & $\mathrm{R} \$ 163,9$ milhões \\
\hline Belo Horizonte & $\mathrm{R} \$ 145,2$ milhões \\
\hline Fortaleza & $\mathrm{R} \$ 135,7$ milhões \\
\hline Curitiba & $\mathrm{R} \$ 90,1$ milhões \\
\hline Goiânia & $\mathrm{R} \$ 73,4$ milhões \\
\hline João Pessoa & $\mathrm{R} \$ 63,4$ milhões \\
\hline
\end{tabular}

Fonte: elaboração própria a partir de BRASIL. Ministério do Planejamento, Orçamento e Gestão, Secretaria de Logística e Tecnologia da Informação - SLTI, cit., p. 126.

No exercício de 2014, o quadro sofreu algumas alteraçōes em relação aos exercícios anteriores. A Região Sudeste passou a dispor do maior volume de repasses, previstos e empenhados, e a Região Sul, do maior volume de recursos executados no exercício.

Tabela 6.5 Volume de transferências voluntárias da União, por região do país, em 2014, segundo valores de repasses, empenho e execução

\begin{tabular}{|c|c|c|c|}
\hline REGIão & VOLUME DE REPASSE & VALOR EMPENHADO & VALOR EXECUTADO \\
\hline Sudeste & $\mathrm{R} \$ 1,878$ bilhão & $\mathrm{R} \$ 1,550$ bilhão & $\mathrm{R} \$ 202$ milhões \\
\hline Nordeste & $\mathrm{R} \$ 1,679$ bilhão & $\mathrm{R} \$ 1,519$ bilhão & $\mathrm{R} \$ 135$ milhões \\
\hline Sul & $\mathrm{R} \$ 1,219$ bilhão & $\mathrm{R} \$ 1,058$ bilhão & $\mathrm{R} \$ 224$ milhões \\
\hline Norte & $\mathrm{R} \$ 661$ milhões & $\mathrm{R} \$ 637$ milhões & $\mathrm{R} \$ 66$ milhões \\
\hline Centro-Oeste & $\mathrm{R} \$ 483$ milhões & $\mathrm{R} \$ 450$ milhões & $\mathrm{R} \$ 57$ milhões \\
\hline
\end{tabular}

Fonte: BRASIL. Ministério do Planejamento, Orçamento e Gestão. Portal dos Convênios - SICONV: Resumo Executivo - 2014. Brasília: Ministério do Planejamento, Orçamento e Gestão, 2015, p. 3.

Dessa forma, observa-se grande variação no perfil das operações quando considerados os diferentes aspectos que cercam as transferências voluntárias, havendo substancial alteração do quadro apresentado, se considerado o volume de repasses previstos ou ajustados, o volume empenhado ou o valor executado. 
Verifica-se, ainda, que a situação se altera quando é considerada a transferência per capita. Conforme dados extraídos do SIAFI GERENCIAL, tomando-se por base os exercícios de 2013 e 2014, a Região Nordeste permanece na primeira posição, com alteração nas demais posições, conforme ilustra a Tabela 6.6.

Tabela 6.6 Transferência per capita, por região do país, em 2013/2014

\begin{tabular}{|c|c|}
\hline REGIÃO & TRANSFERÊNCIA PER CAPITA (R\$) \\
\hline Nordeste & 72,88 \\
\hline Norte & 72,10 \\
\hline Centro-Oeste & 52,60 \\
\hline Sul & 51,22 \\
\hline Sudeste & 42,56 \\
\hline
\end{tabular}

Fonte: BRASIL. Secretaria do Tesouro Nacional; Coordenação-Geral de Análise e Informaçôes das Transferências Financeiras Governamentais. Transferências voluntárias a Estados, DF e Municipios - dezembro/2014. Brasília: Secretaria do Tesouro Nacional, 2015.

No tocante aos Estados, o quadro também se altera se levado em consideração o volume de recursos transferidos per capita.

Tabela 6.7 Transferência per capita, por Estado, em 2013/2014

\begin{tabular}{|c|c|}
\hline ESTADO & TRANSFERÊNCIA PER CAPITA (R\$) \\
\hline Acre & 124,53 \\
\hline Tocantins & 89,87 \\
\hline Maranhão & 83,13 \\
\hline Paraíba & 80,51 \\
\hline Alagoas & 80,45 \\
\hline Ceará & 76,06 \\
\hline Amapá & 74,87 \\
\hline Roraima & 74,47 \\
\hline Rio Grande do Norte & 73,42 \\
\hline Mato Grosso & 71,75 \\
\hline
\end{tabular}

Fonte: BRASIL. Secretaria do Tesouro Nacional; Coordenação-Geral de Análise e Informaçôes das Transferências Financeiras Governamentais, cit., p. 238. 
Apenas a título de informação, percebe-se que os Estados com o menor volume de transferências per capita são Rio de Janeiro e São Paulo, com o valor respectivo de $\mathrm{R} \$ 35,14$ e R \$38,35, além do Distrito Federal, com valor per capita de R \$23,01.

Todas essas considerações não são feitas para corroborar ou rechaçar os objetivos do federalismo cooperativo, particularmente focado no desenvolvimento nacional e na igualação das condições econômico-sociais das regiôes, mas apenas para fazer uma breve apresentação do perfil dos repasses de recursos delineado atualmente na Federação brasileira.

\subsubsection{Relação entre o volume de recursos e a natureza do ente federativo}

Os entes que mais recebem transferências voluntárias da União são os Municípios. A estatística se explica em razão da quantidade muito mais expressiva de Municípios existentes no país, quando comparada ao número de Estados, bem como pela situação de extrema dependência de recursos advindos de transferências intergovernamentais por grande número deles. ${ }^{2-3}$ Outra constatação é de que o número de convênios realizados com as capitais é inferior ao das demais cidades, mas seus valores são bastante expressivos. Nesse sentido, analisando as transferências recebidas pelos Municípios sergipanos, salientam Adriano de Souza Cesar e Vanilda Lima Monteiro:

(...) o que confirma a percepção de que os convênios celebrados com a Capital possuem valores bem superiores aos celebrados com os Municípios do interior, fato que pode ser explicado pela necessidade de manter serviços de referência no Estado nas áreas de educação, saúde, segurança e turismo, além da necessidade de realizar obras de maior porte para habitação popular e infra-estrutura urbana (...). ${ }^{4}$

Essa situação retrata a diferença das finalidades dos ajustes envolvendo transferências voluntárias celebrados com capitais ou cidades mais desenvolvidas, se comparados com os ajustes celebrados com Municípios do interior.

Além das transferências aos Estados e Municípios, também há aquelas destinadas a consórcios públicos, empresas públicas e sociedades de economia

2 BRASIL. Ministério do Planejamento, Orçamento e Gestão, cit.

3 BRASIL. Portal Brasil. Municípios recebem 77\% das transferências voluntárias da União de janeiro a junho. Portal Brasil, publicado em 9 jul. 2012, última modificação em 29 jul. 2014. Disponível em: <http://www.brasil.gov.br/governo/2012/07/municipios-recebem-77-das-transferencias-voluntarias-da-uniao-de-janeiro-a-junho>. Acesso em: 31 ago. 2015.

4 CESAR, Adriano de Souza; MONTEIRO, Vanilda Lima. Recursos públicos federais transferidos aos Municipios sergipanos por meio de convênio ou contrato de repasse: providências indispensáveis à sua adequada gestão. Aracaju: Faculdade de Administração e Negócios de Sergipe (FANESE), p. 134. 
mista e entidades privadas sem fins lucrativos. Embora as transferências voluntárias propriamente ditas, objeto do presente estudo, se circunscrevam aos repasses efetuados diretamente à Administração direta de Estados e Municípios, mostra-se relevante a proporção alcançada pelas operações no contexto das transferências discricionárias amplamente consideradas.

Apenas a título de exemplo, no exercício de 2013, o volume de transferências foi distribuído nos seguintes patamares:

Tabela 6.8 Volume de transferências, em 2013, segundo natureza jurídica do destinatário, valor do repasse, do empenho, da execução e quantidade de transferências

\begin{tabular}{|c|c|c|c|c|}
\hline $\begin{array}{c}\text { NATUREZA } \\
\text { JURÍDICA }\end{array}$ & $\begin{array}{c}\text { VALOR DO } \\
\text { REPASSE (RS) }\end{array}$ & $\begin{array}{c}\text { EMPENHO } \\
\text { (RS) }\end{array}$ & $\begin{array}{c}\text { EXECUÇÃO } \\
\text { FINANCEIRA (RS) }\end{array}$ & $\begin{array}{c}\text { QUANTIDADE DE } \\
\text { TRANSFERÊNCIAS }\end{array}$ \\
\hline $\begin{array}{c}\text { Estados/DF } \\
\text { (Adm. Pública) }\end{array}$ & 4,860 bilhões & 3,013 bilhões & 1,075 bilhão & 1.543 \\
\hline $\begin{array}{c}\text { Municípios } \\
\text { (Adm. Pública) }\end{array}$ & 4,657 bilhões & 4,126 bilhões & 502 milhões & 8.482 \\
\hline $\begin{array}{c}\text { Entidades } \\
\text { privadas sem fins } \\
\text { lucrativos }\end{array}$ & 2,017 bilhões & 1,4 bilhões & 1,077 bilhão & 1.304 \\
\hline $\begin{array}{c}\text { Empresas públicas } \\
\text { e sociedades de } \\
\text { economia mista }\end{array}$ & 433 milhões & 290 milhões & 186 milhões & 88 \\
\hline $\begin{array}{c}\text { Consórcios } \\
\text { Públicos }\end{array}$ & 11,876 milhões & 9,351 milhões & 3,127 milhões & 13 \\
\hline
\end{tabular}

Fonte: elaboração própria a partir de BRASIL. Ministério do Planejamento, Orçamento e Gestão, Secretaria de Logística e Tecnologia da Informação - SLTI, cit., p. 126.

Observa-se, dessa feita, que a grande maioria dos ajustes - em torno de $74 \%$ - envolve as Administrações Públicas municipais. No tocante ao volume de recursos de repasses, por sua vez, predominam as transferências destinadas aos Estados.

\subsubsection{Importância dos convênios na receita dos Estados e Municípios}

A importância das transferências voluntárias da União para os Estados e Municípios e dos Estados para os Municípios constituiu objeto de atenção por parte de alguns estudiosos do tema. 
Ao analisar a relevância do instituto no contexto federativo brasileiro, Maria da Conceição Silva conclui que as transferências da União são muito mais relevantes para os Municípios do que para os Estados. Aponta que as áreas que mais receberam recursos foram educação e saúde, assim como outras que figuram entre as competências comuns às três esferas da Federação. ${ }^{5}$ Assim, tomando como exemplo os dados dos Estados de São Paulo e Rio de Janeiro, bem como de seus Municípios, a autora ressalta a maior importância das transferências na esfera dos Municípios do que na esfera estadual.

Além disso, as capitais têm um volume maior de receitas tributárias próprias do que o montante dos Municípios do interior. Em São Paulo, a capital possuía um percentual de $42 \%$ da receita advindo de seus próprios impostos e taxas, ao passo que nos Municípios do interior essa participação é de $18 \%$. As mesmas percentagens para o Estado do Rio de Janeiro eram de 37\% e 16\%, respectivamente. De outra sorte, o percentual das transferências correntes é maior nos Municípios do interior, alcançando $63 \%$, em relação aos das capitais - $41 \%$ na capital paulista e 44\% no Rio de Janeiro, em 2000.

A autora também tece algumas consideraçôes acerca do registro contábil das receitas. Em relação aos recursos vinculados à saúde, aponta que:

(...) as diferenças de classificação dizem respeito àqueles destinados regularmente ao SUS e aos recursos repassados através de convênios para gastos específicos na área da saúde. Casos em que os valores registrados na rubrica "convênio com o SUS" apresentem-se relativamente muito elevados podem estar superestimando os valores das transferências voluntárias. Contudo, com a Emenda Constitucional 29/2000, que vinculou recursos à saúde, a distinção entre convênios e transferências vinculadas deverá ficar clara nos registros contábeis. ${ }^{6}$

Fica desde então registrada a necessidade de se proceder a registros mais criteriosos, que reflitam efetivamente o volume de recursos destinados a cada título. Segundo a autora, "Estes aspectos foram salientados com o objetivo de alertar para o fato de que análises mais desagregadas das finanças municipais requerem uma reclassificação criteriosa dos dados dos balanços"?

No tocante às transferências de capital, Maria da Conceição Silva identifica novamente a discrepância nos registros contábeis, verificada especialmente pela classificação dos royalties de petróleo recebidos pelos Municípios fluminenses como

5 SILVA, Maria da Conceição. Mecanismos de cooperação financeira de estados e Municípios: São Paulo e Rio de Janeiro. In: SILVA, Fernando Antonio Rezende da; OLIVEIRA, Fabrício Augusto de. Descentralização e federalismo fiscal no Brasil: desafios da reforma tributária. Rio de Janeiro: Konrad Adenauer Stiftung; Fundação Getulio Vargas, 2003, p. 149-201.

6 SILVA, Maria da Conceição, cit., p. 154.

7 SILVA, Maria da Conceição, cit., p. 154. 
transferências de capital, ao lado das receitas de convênios e do Fundo de Participação dos Municípios. Nesse sentido, a autora afirma:

A principal conclusão que se pode extrair da análise desta seção refere-se ao registro contábil dos dados orçamentários. A Lei Kandir, a instituição do Fundef, a distribuição dos royalties do petróleo e a renegociação da dívida trouxeram mudanças significativas nos balanços dos estados e Municípios, que terão que ser consideradas em análises da estrutura da receita orçamentária. A diversidade de tratamento, sobretudo entre os Municípios, conferida a alguns desses itens - Fundef, convênios e royalties de petróleo - imprimiu um elevado grau de heterogeneidade nas informações. ${ }^{8}$

A forma de classificação das receitas advindas de transferências voluntárias pelos Estados e Municípios enquanto transferências de convênios, dentro das receitas correntes e de capital, constitui outro fator que dificulta a consolidação dos dados característicos das transferências voluntárias, que acabam se diluindo em outras categorias e classificaçôes.?

Torna-se necessária, assim, uma reclassificação das receitas como forma de tornar mais clara a origem dos recursos e também sua destinação, voltada a um melhor conhecimento da realidade das finanças públicas de cada uma das unidades da federação.

\subsection{A TRANSPARÊNCIA NAS TRANSFERÊNCIAS VOLUNTÁRIAS}

A Lei Complementar n. 131, de 27 de maio de 2009, introduziu alguns dispositivos na Lei de Responsabilidade Fiscal, com vistas a impor uma maior transparência aos atos de execução orçamentária. Com base em referido diploma, que fixou inclusive prazos para seu cumprimento, foram criados os portais de transparência federal, estaduais e municipais:

Art. $1^{\circ} \mathrm{O}$ art. 48 da Lei Complementar n. 101, de 4 de maio de 2000, passa a vigorar com a seguinte redação:

Art. 48. (...)

Parágrafo único. A transparência será assegurada também mediante:

I - incentivo à participação popular e realização de audiências públicas, durante os processos de elaboração e discussão dos planos, lei de diretrizes orçamentárias e orçamentos;

II - liberaçáo ao pleno conhecimento e acompanhamento da sociedade, em tempo real, de informaçóes pormenorizadas sobre a execução orçamentária e financeira, em meios eletrônicos de acesso público;

8 SILVA, Maria da Conceição, cit., p. 159.

9 SILVA, Maria da Conceição, cit., p. 160. 
III - adoção de sistema integrado de administração financeira e controle, que atenda a padrão mínimo de qualidade estabelecido pelo Poder Executivo da União e ao disposto no art. 48-A.

Art. 20 A Lei Complementar n. 101, de 4 de maio de 2000, passa a vigorar acrescida dos seguintes arts. 48-A, 73-A, 73-B e 73-C:

Art. 48-A. Para os fins a que se refere o inciso II do parágrafo único do art. 48, os entes da Federação disponibilizarão a qualquer pessoa física ou jurídica o acesso a informações referentes a:

I - quanto à despesa: todos os atos praticados pelas unidades gestoras no decorrer da execução da despesa, no momento de sua realização, com a disponibilização mínima dos dados referentes ao número do correspondente processo, ao bem fornecido ou ao serviço prestado, à pessoa física ou jurídica beneficiária do pagamento e, quando for o caso, ao procedimento licitatório realizado;

II - quanto à receita: o lançamento e o recebimento de toda a receita das unidades gestoras, inclusive referente a recursos extraordinários.

Art. 73-A. Qualquer cidadão, partido político, associação ou sindicato é parte legítima para denunciar ao respectivo Tribunal de Contas e ao órgão competente do Ministério Público o descumprimento das prescrições estabelecidas nesta Lei Complementar.

Art. 73-B. Ficam estabelecidos os seguintes prazos para o cumprimento das determinações dispostas nos incisos II e III do parágrafo único do art. 48 e do art. 48-A:

I - 1 (um) ano para a União, os Estados, o Distrito Federal e os Municípios com mais de 100.000 (cem mil) habitantes;

II - 2 (dois) anos para os Municípios que tenham entre 50.000 (cinquenta mil) e 100.000 (cem mil) habitantes;

III - 4 (quatro) anos para os Municípios que tenham até 50.000 (cinquenta mil) habitantes.

Parágrafo único. Os prazos estabelecidos neste artigo serão contados a partir da data de publicação da lei complementar que introduziu os dispositivos referidos no caput deste artigo.

Art. 73-C. O não atendimento, até o encerramento dos prazos previstos no art. 73-B, das determinações contidas nos incisos II e III do parágrafo único do art. 48 e no art. 48-A sujeita o ente à sanção prevista no inciso I do $\$ 3^{\circ}$ do art. 23. (Grifo nosso)

No entanto, poucos entes da federação, como o Estado do Rio de Janeiro, dispóem de dados suficientemente claros acerca dos repasses efetuados a título de transferências voluntárias, que não são verificados sequer na esfera da própria União Federal. Ainda que formalmente disponibilizados, os dados relacionados à gestão orçamentária de repasses de recursos entre os entes federados não se mostram transparentes o suficiente. Não se garante, assim, a plenitude do direito de acesso à informação, na medida em que a forma como os dados encontram-se disponibilizados dificulta as consultas e a obtenção efetiva de resultados. 
Dessa maneira, não obstante a ampla divulgação de números concernentes aos ajustes celebrados, a transparência das informaçôes relativas às transferências voluntárias é altamente deficitária, situação exemplificada pela própria ausência de dados consolidados específicos. Muitas vezes, o interessado deve elaborar cálculos para obter o volume de recursos transferidos voluntariamente, de forma ao menos aproximada, o que, além de contrariar os ditames do princípio da transparência, impede o real conhecimento do impacto dessas operações no orçamento das unidades federativas e, consequentemente, o seu grau de dependência financeira em relação às demais.

Os portais da transparência disponibilizam dados relativos aos repasses de recursos efetuados e recebidos, mas de forma bastante abrangente. O próprio Portal de Transparência dos Recursos Federais não apresenta uma consolidação específica do volume de transferências voluntárias, na forma delimitada pelo artigo 25 da Lei de Responsabilidade Fiscal, muito embora diversos dados relativos a transferências de recursos se encontrem disponibilizados. Observa-se que a ausência de dados específicos consolidados acaba por reclamar, do interessado, conhecimentos prévios da matéria, sob pena de frustrar o resultado da pesquisa.

A ausência de precisão das informações disponibilizadas pelo Portal é ilustrada por aviso constante na própria página de acesso ao Portal da Transparência dos Recursos Públicos Federais:

Aviso: Os recursos apresentados por área referem-se apenas à consolidação por função orçamentária dos valores transferidos pelo Governo Federal aos estados e Municípios, conforme classificação da despesa no Sistema Integrado de Administração Financeira (Siafi) e não refletem a totalidade dos gastos do Governo Federal nessas áreas.

A falta de consolidaçôes específicas acerca das transferências voluntárias efetuadas pela União, ao menos até o exercício de $2015,{ }^{10}$ e a própria conceituação dessas transferências por meio de um método que envolve uma série de exclusões, são fatores determinantes para a complexidade e imprecisão da definição do volume dessas operações. Cabe ao intérprete elaborar esses cálculos por meio da exclusão inicial das parcelas que compõem as transferências constitucionais e legais.

Nesse aspecto, um mecanismo auxiliar de aferição do volume de transferências voluntárias da União que merece destaque é a classificação de parte das transferências

10 Por meio de proposta apresentada pelo Subgrupo de Trabalho voltado à classificação das transferências da União, constituído por representantes da Secretaria do Tesouro Nacional do Ministério da Fazenda, da Secretaria de Orçamento Federal e da Secretaria de Logística e Tecnologia da Informação, ambas do Ministério Planejamento, Orçamento e Gestão e da Controladoria-Geral da União, a Secretaria do Tesouro Nacional passou a apresentar dados consolidados das transferências voluntárias, especialmente no tocante às unidades da Federação e às regiōes geográficas. Atente-se ao fato de que não se trata de modelo ideal, requerendo avanços especialmente na publicação de dados mais detalhados sobre as transferências efetuadas. No entanto, ainda assim ele permite uma visão mais acurada do perfil das transferências voluntárias entre os entes da federação. 
obrigatórias como "Encargos Especiais" ${ }^{11}$ Sob o ponto de vista prático, elas representam o valor obtido a partir da soma do volume das parcelas componentes das transferências constitucionais e legais (FPE, FPM, FUNDEF, ITR, IOF-ouro, FPEX, Lei Complementar n. 87/96, Cota-parte do Salário-Educação, Compensações Financeiras, e transferências decorrentes dos concursos de prognósticos), o que permite, em tese, a obtenção do volume das transferências voluntárias, por meio da subtração dos valores componentes dos Encargos Especiais do volume total de transferências realizadas pelo ente federado.

Em suma, conforme restou salientado, exige-se um claro esforço por parte do próprio interessado na identificação do real cenário das transferências voluntárias em um contexto cercado por inexatidôes, como forma de aferir o volume aproximado das transferências efetuadas e recebidas. Além disso, para se categorizar determinado repasse como transferência voluntária ou não, é necessário verificar se a operação em análise foi destinada a um ente federado, caracterizando a transferência voluntária stricto sensu, nos termos do artigo 25 da LRF, ou a uma entidade de natureza privada situada na respectiva esfera federativa, hipótese que não deve ser considerada para fins do cálculo do volume de transferências voluntárias.

Percebe-se, assim, a extrema complexidade da análise, o que reclama uma urgente adaptação das informações veiculadas pelos Portais de Transparência para o pleno atingimento dos fins preconizados pelo princípio da transparência e publicidade dos atos da administração.

\subsubsection{Transferências de recursos por Estado/Município}

As dificuldades para o retrato do quadro real das transferências voluntárias e o contexto de inexatidão no qual se inserem refletem-se nos números apresentados para essas operaçôes, haja vista a diferença entre o quadro geral das transferências de recursos e o resultado obtido na aplicação dos filtros. Conforme dados disponibilizados pelo Portal da Transparência, no período de 2010 a 2014, os cinco Estados que mais receberam recursos da União, em números absolutos, foram os seguintes:

11 Conforme definição extraída do Glossário do Portal da Transparência dos Recursos Públicos Federais, “a função Encargos Especiais engloba as despesas em relação às quais não se pode associar um bem ou serviço a ser gerado no processo produtivo corrente, tais como: dívidas, ressarcimentos, indenizações e outras afins, representando, portanto, uma agregação neutra. O termo "Encargos Especiais" também poderá estar associado à subfunção 846 - Outros Encargos Especiais, assim como a Programas, tais como: 0901 - Operações Especiais: Cumprimento De Sentenças Judiciais; 0902 - Operações Especiais: Financiamentos com Retorno; e 0903 - Operaçôes Especiais: Transferências Constitucionais e decorrentes de Legislação Específica" (grifo nosso). Disponível em <http://www.portaltransparencia.gov.br/glossario/ DetalheGlossario.asp?letra=e $>$. Acesso em 18/12/2015. 
Quadro 6.1 Estados que receberam mais recursos da União, em números absolutos, entre 2010 e 2014

\begin{tabular}{|c|c|c|c|c|c|}
\hline EXERCÍCIO/COLOCAÇÃO & $\mathbf{2 0 1 0}$ & $\mathbf{2 0 1 1}$ & $\mathbf{2 0 1 2}$ & $\mathbf{2 0 1 3}$ & $\mathbf{2 0 1 4}$ \\
\hline $\mathbf{1}^{\circ}$ & $\mathrm{RJ}$ & $\mathrm{RJ}$ & $\mathrm{RJ}$ & $\mathrm{RJ}$ & $\mathrm{RJ}$ \\
\hline $\mathbf{2}^{\circ}$ & $\mathrm{SP}$ & $\mathrm{BA}$ & $\mathrm{BA}$ & $\mathrm{BA}$ & $\mathrm{BA}$ \\
\hline $\mathbf{3}^{\circ}$ & $\mathrm{BA}$ & $\mathrm{SP}$ & $\mathrm{MG}$ & $\mathrm{MG}$ & $\mathrm{MG}$ \\
\hline $\mathbf{4}^{\circ}$ & $\mathrm{MG}$ & $\mathrm{MG}$ & $\mathrm{SP}$ & $\mathrm{SP}$ & $\mathrm{SP}$ \\
\hline $\mathbf{5}^{\circ}$ & $\mathrm{PE}$ & $\mathrm{PE}$ & $\mathrm{PE}$ & $\mathrm{PE}$ & $\mathrm{MA}$ \\
\hline
\end{tabular}

Fonte: elaboração própria a partir de BRASIL. Controladoria-Geral da União. Portal da Transparência nos Recursos Públicos Federais. Disponível em: <http://www.portaltransparencia. gov.br/>. Acesso em: $18 \mathrm{dez} .2015$.

Considerando, por sua vez, o cálculo do volume de transferências voluntárias por meio da exclusão das transferências constitucionais e legais, o cenário se reverte. Adotando-se como exemplo o Estado de São Paulo, mediante aplicação dos cálculos de exclusão, observa-se, no exercício de 2014, que o montante de transferências voluntárias representa 9,99\% do valor total de transferências.

Tabela 6.8 Valores absolutos de transferências voluntárias, em 2014, para o Estado de São Paulo, segundo cálculo que exclui as transferências constitucionais e legais

\begin{tabular}{|c|c|}
\hline REGISTRO & VALOR (EM R\$) \\
\hline Volume total de transferências & $6.586 .088 .599,69$ \\
\hline Abatimentos & $5.928 .073 .055,31$ \\
\hline Cota-parte do salário educação & $2.242 .639 .681,89$ \\
\hline FUNDEB & $1.313 .280 .992,99$ \\
\hline Cota-parte do IPI & $777.620 .279,30$ \\
\hline Fundo de Participação dos Estados & $580.861 .579,35$ \\
\hline Royalties & $366.440 .378,48$ \\
\hline Transferências Lei Complementar n. 87/96 & $364.359 .060,00$ \\
\hline Royalties & $187.474 .350,11$ \\
\hline Compensação de exportação (CEX) & $61.275 .532,50$ \\
\hline CFEM - compensação & $15.573 .810,44$ \\
\hline CIDE (combustíveis) & $15.554 .220,93$ \\
\hline Royalties & $2.982 .507,37$ \\
\hline Transferência de IOF para Estados e Distrito & $10.661,95$ \\
\hline Federal - Lei Federal n. 7.766 & $658.015 .544,38$ \\
\hline Total de volume após abatimentos & \\
\hline
\end{tabular}

Fonte: elaboração própria a partir de BRASIL. Controladoria-Geral da União, cit., p. 247. 
No tocante ao exercício de 2013, a situação é bastante parecida, resultando num montante que representa $10,45 \%$ do valor total.

Tabela 6.9 Valores absolutos de transferências voluntárias, em 2013, para o Estado de São Paulo, segundo cálculo que exclui as transferências constitucionais e legais

\begin{tabular}{|c|c|}
\hline REGISTRO & $\begin{array}{l}\text { VALOR } \\
(\text { EM R\$) }\end{array}$ \\
\hline Volume total de transferências & $5.703 .245 .818,71$ \\
\hline Abatimentos & $5.107 .302 .297,73$ \\
\hline $\begin{array}{l}\text { Cota-parte do salário } \\
\text { educação }\end{array}$ & 2.078.276.894,04 \\
\hline FUNDEB & 1.221.674.131,44 \\
\hline Cota-parte do IPI & $714.768 .011,63$ \\
\hline $\begin{array}{c}\text { Fundo de Participação } \\
\text { dos Estados }\end{array}$ & $533.041 .683,68$ \\
\hline $\begin{array}{c}\text { Transferências Lei Complementar } \\
\text { n. } 87 / 96\end{array}$ & $364.359 .060,00$ \\
\hline Royalties & $147.771 .234,43$ \\
\hline Royalties & $24.297 .943,48$ \\
\hline CFEM - compensação & $12.764 .865,65$ \\
\hline CIDE (combustíveis) & $7.685 .249,15$ \\
\hline Royalties & 2.605.646,87 \\
\hline $\begin{array}{l}\text { Transferência de IOF para Estados } \\
\text { e Distrito Federal - Lei Federal n. } 7.766\end{array}$ & $57.577,36$ \\
\hline $\begin{array}{l}\text { Total de volume após } \\
\text { abatimentos }\end{array}$ & $595.943 .520,98$ \\
\hline
\end{tabular}

Fonte: elaboração própria a partir de BRASIL. Controladoria-Geral da União, cit., p. 247.

Exercício semelhante pode ser efetuado com os dados relacionados ao Estado do Rio de Janeiro, nos exercícios de 2014 e 2013. Em 2014, o volume de transferências voluntárias, segundo esse cálculo, representou 3,59\% do montante total, enquanto esse percentual foi de 5,34\%, em 2013. 
Tabela 6.10 Valores absolutos de transferências voluntárias, em 2014, para o Estado do Rio de Janeiro, segundo cálculo que exclui as transferências constitucionais e legais

\begin{tabular}{|c|c|}
\hline REGISTRO & $\begin{array}{l}\text { VALOR } \\
\text { (EM R\$) }\end{array}$ \\
\hline $\begin{array}{c}\text { Volume total } \\
\text { de transferências }\end{array}$ & $11.505 .690 .520,80$ \\
\hline Abatimentos & $11.092 .053 .443,29$ \\
\hline Royalties & $5.492 .211 .661,40$ \\
\hline Royalties & $3.213 .771 .453,88$ \\
\hline $\begin{array}{l}\text { Fundo de Participação } \\
\text { dos Estados }\end{array}$ & $887.382 .234,61$ \\
\hline Cota-parte do IPI & $655.954 .588,08$ \\
\hline $\begin{array}{c}\text { Cota-parte do salário } \\
\text { educação }\end{array}$ & $429.057 .979,90$ \\
\hline FUNDEB & $283.000 .864,31$ \\
\hline $\begin{array}{l}\text { Transferências Lei Complementar } \\
\qquad \text { n. 87/96 }\end{array}$ & $68.620 .851,00$ \\
\hline $\begin{array}{c}\text { Compensação de exportação } \\
\text { (CEX) }\end{array}$ & $48.685 .016,25$ \\
\hline Royalties & $4.556 .376,50$ \\
\hline CIDE (combustíveis) & 4.441.618,56 \\
\hline CFEM - compensação & $4.339 .497,16$ \\
\hline $\begin{array}{c}\text { Transferência de IOF para Estados } \\
\text { e Distrito Federal } \\
\text { - Lei Federal n. } 7.766\end{array}$ & $31.231,64$ \\
\hline $\begin{array}{l}\text { Total de volume após } \\
\text { abatimentos }\end{array}$ & $413.637 .077,51$ \\
\hline
\end{tabular}

Fonte: elaboração própria a partir de BRASIL. Controladoria-Geral da União, cit., p. 247. 
Tabela 6.11 Valores absolutos de transferências voluntárias, em 2013, para o Estado do Rio de Janeiro, segundo cálculo que exclui as transferências constitucionais e legais

\begin{tabular}{|c|c|}
\hline REGISTRO & $\begin{array}{c}\text { VALOR } \\
\text { (EM RS) }\end{array}$ \\
\hline Volume total de transferências & $11.073 .183 .263,55$ \\
\hline Abatimentos & $10.481 .261 .951,35$ \\
\hline Royalties & $5.240 .161 .464,41$ \\
\hline Royalties & $2.982 .024 .867,88$ \\
\hline Fundo de Participação & $814.327 .780,07$ \\
\hline dos Estados & $678.261 .771,57$ \\
\hline Cota-parte do IPI & $411.596 .267,40$ \\
\hline Cota-parte do salário educação & $276.423 .711,81$ \\
\hline FuNDEB & $68.620 .851,00$ \\
\hline Transferência de IOF para Estados e Distrito & $3.980 .646,74$ \\
\hline Rotal dei Federal n. 7.766 & $3.624 .257,71$ \\
\hline CFEM - compensação & $591.921 .312,20$ \\
\hline
\end{tabular}

Fonte: elaboração própria a partir de BRASIL. Controladoria-Geral da União, cit., p. 247.

Com base nos dados coligidos, verifica-se nova composição da tabela com os Estados com maior volume de recursos transferidos voluntariamente. No Quadro 6.2. e no Quadro 6.3 comparam-se as posições segundo os dois tipos de cálculos. 
Quadro 6.2 Estados que receberam mais recursos da União, em números absolutos, entre 2010 e 2014, segundo dados do Portal da Transparência

\begin{tabular}{|c|c|c|c|c|c|}
\hline $\begin{array}{c}\text { EXERCÍCIO } \\
\text { COLOCAÇÃo }\end{array}$ & $\mathbf{2 0 1 0}$ & $\mathbf{2 0 1 1}$ & $\mathbf{2 0 1 2}$ & $\mathbf{2 0 1 3}$ & $\mathbf{2 0 1 4}$ \\
\hline $\mathbf{1}^{\circ}$ & $\mathrm{RJ}$ & $\mathrm{RJ}$ & $\mathrm{RJ}$ & $\mathrm{RJ}$ & $\mathrm{RJ}$ \\
\hline $\mathbf{2}^{\circ}$ & $\mathrm{SP}$ & $\mathrm{BA}$ & $\mathrm{BA}$ & $\mathrm{BA}$ & $\mathrm{BA}$ \\
\hline $\mathbf{3}^{\circ}$ & $\mathrm{BA}$ & $\mathrm{SP}$ & $\mathrm{MG}$ & $\mathrm{MG}$ & $\mathrm{MG}$ \\
\hline $\mathbf{4}^{\circ}$ & $\mathrm{MG}$ & $\mathrm{MG}$ & $\mathrm{SP}$ & $\mathrm{SP}$ & $\mathrm{SP}$ \\
\hline $\mathbf{5}^{\circ}$ & $\mathrm{PE}$ & $\mathrm{PE}$ & $\mathrm{PE}$ & $\mathrm{PE}$ & $\mathrm{MA}$ \\
\hline
\end{tabular}

Fonte: elaboração própria a partir de BRASIL. Controladoria-Geral da União, cit., p. 247.

Quadro 6.3 Estados que receberam mais recursos da União, em números absolutos, entre 2010 e 2014, segundo cálculo que exclui as transferências constitucionais e legais

\begin{tabular}{|c|c|c|c|c|c|}
\hline $\begin{array}{c}\text { EXERCÍCIO } \\
\text { COLOCAÇÃo }\end{array}$ & $\mathbf{2 0 1 0}$ & $\mathbf{2 0 1 1}$ & $\mathbf{2 0 1 2}$ & $\mathbf{2 0 1 3}$ & $\mathbf{2 0 1 4}$ \\
\hline $\mathbf{1}^{\circ}$ & $\mathrm{SP}$ & $\mathrm{SP}$ & $\mathrm{PE}$ & $\mathrm{BA}$ & $\mathrm{PE}$ \\
\hline $\mathbf{2}^{\circ}$ & $\mathrm{PE}$ & $\mathrm{MG}$ & $\mathrm{MG}$ & $\mathrm{PE}$ & $\mathrm{BA}$ \\
\hline $\mathbf{3}^{\circ}$ & $\mathrm{BA}$ & $\mathrm{BA}$ & $\mathrm{BA}$ & $\mathrm{MA}$ & $\mathrm{CE}$ \\
\hline $\mathbf{4}^{\circ}$ & $\mathrm{MG}$ & $\mathrm{PE}$ & $\mathrm{SP}$ & $\mathrm{CE}$ & $\mathrm{MA}$ \\
\hline $5^{\circ}$ & $\mathrm{RJ}$ & $\mathrm{RJ}$ & $\mathrm{AL}$ & $\mathrm{PA}$ & $\mathrm{AL}$ \\
\hline
\end{tabular}

Fonte: elaboração própria a partir de BRASIL. Controladoria-Geral da União, cit., p. 247.

De outra sorte, os Estados que receberam menos recursos no período, considerando a totalidade dos recursos transferidos, estão discriminados no Quadro 6.4. 
Quadro 6.4 Estados que receberam menos recursos da União, em números absolutos, entre 2010 e 2014, segundo dados do Portal da Transparência

\begin{tabular}{|c|c|c|c|c|c|}
\hline $\begin{array}{c}\text { EXERCíCIO } \\
\text { COLOCAÇÃO }\end{array}$ & $\mathbf{2 0 1 0}$ & $\mathbf{2 0 1 1}$ & $\mathbf{2 0 1 2}$ & $\mathbf{2 0 1 3}$ & $\mathbf{2 0 1 4}$ \\
\hline $\mathbf{1}^{\circ}$ & DF & DF & DF & DF & DF \\
\hline $2^{\circ}$ & MS & MS & MS & MS & MS \\
\hline $3^{\circ}$ & RR & RR & SC & SC & SC \\
\hline $4^{\circ}$ & RO & RO & RO & RR & RR \\
\hline $5^{\circ}$ & SC & SC & MT & RO & RO \\
\hline
\end{tabular}

Fonte: elaboração própria a partir de BRASIL. Controladoria-Geral da União, cit., p. 247.

Considerando-se apenas os recursos repassados por meio de transferências voluntárias, o quadro também se altera.

Quadro 6.5 Estados que receberam menos recursos da União, em números absolutos, entre 2010 e 2014, segundo cálculo que exclui as transferências constitucionais e legais

\begin{tabular}{|c|c|c|c|c|c|}
\hline $\begin{array}{c}\text { EXERCíCIO } \\
\text { COLOCAÇÃO }\end{array}$ & $\mathbf{2 0 1 0}$ & $\mathbf{2 0 1 1}$ & $\mathbf{2 0 1 2}$ & $\mathbf{2 0 1 3}$ & $\mathbf{2 0 1 4}$ \\
\hline $\mathbf{1}^{\circ}$ & $\mathrm{AP}$ & $\mathrm{RO}$ & $\mathrm{PI}$ & $\mathrm{RO}$ & $\mathrm{RR}$ \\
\hline $\mathbf{2}^{\circ}$ & $\mathrm{RO}$ & $\mathrm{TO}$ & $\mathrm{PB}$ & $\mathrm{TO}$ & $\mathrm{AP}$ \\
\hline $3^{\circ}$ & $\mathrm{RR}$ & $\mathrm{AP}$ & $\mathrm{MT}$ & $\mathrm{RR}$ & $\mathrm{RO}$ \\
\hline $\mathbf{4}^{\circ}$ & $\mathrm{GO}$ & $\mathrm{GO}$ & $\mathrm{RO}$ & $\mathrm{ES}$ & $\mathrm{ES}$ \\
\hline $5^{\circ}$ & $\mathrm{PB}$ & $\mathrm{PB}$ & $\mathrm{GO}$ & $\mathrm{AP}$ & $\mathrm{TO}$ \\
\hline
\end{tabular}

Fonte: elaboração própria a partir de BRASIL. Controladoria-Geral da União, cit., p. 247.

Em síntese, a mera divulgação dos dados relativos às transferências de recursos por ente da federação apresenta-se de forma bastante diferenciada se o objetivo perseguido é a delimitação do volume de transferências voluntárias de recursos, demandando a realização de outros tipos de pesquisas e operações. 


\subsubsection{Dissonância entre os números alcançados de acordo com o critério de busca efetuada no Portal da Transparência Federal}

Além da ausência de critérios que permitam a caracterização das transferências realizadas como obrigatórias ou voluntárias, outra inconsistência refere-se à dissonância entre os números alcançados de acordo com o critério de busca efetuada no Portal da Transparência dos Recursos Públicos Federais. Tomando-se como exemplo o Estado de Santa Catarina, mediante a aplicação de diferentes critérios de busca, com vistas a delimitar o volume de transferências voluntárias efetuadas ao Estado, foram alcançados os seguintes resultados:

a) pesquisa por Transferências de Recursos - exercício 2014, consulta por Ente favorecido (Entes governamentais). Resultado: O total destinado ao favorecido ESTADO DE SANTA CATARINA é de R\$ 1.443.915.072,86.

Abatendo-se, desse total, os valores transferidos a título de Encargos Especiais (Compensação de Exportação-CEX, FUDEB, FPE-CF art. 159, CIDE-Combustíveis, Transferências da LC n. 87/96 e da LC n. 115/2003, Cota-Parte IPI da LC n. 61, CFEM, Royalties e Transferência - IOF - Estados e DF - Lei n. 7.766), alcança-se o valor de $\mathrm{R} \$ 17.994 .973,65$, que, em tese, seria o volume de transferências voluntárias destinadas pela União ao Estado de Santa Catarina.

Tabela 6.12 Valores absolutos de encargos especiais, em 2014, para o Estado de Santa Catarina, segundo cálculo que exclui as transferências constitucionais e legais

\begin{tabular}{|c|c|}
\hline REGISTRO & $\begin{array}{c}\text { VALOR } \\
\text { (EM RS) }\end{array}$ \\
\hline $\begin{array}{c}\text { Volume total de transferências } \\
\text { destinadas ao Estado }\end{array}$ & $1.443 .915 .072,86$ \\
\hline $\begin{array}{c}\text { Volume total de encargos } \\
\text { especiais }\end{array}$ & $17.994 .973,65$ \\
\hline
\end{tabular}

Fonte: elaboração própria a partir de BRASIL. Controladoria-Geral da União, cit., p. 247.

b) pesquisa por Transferências de Recursos - exercício 2014, consulta por Estado/Município - Santa Catarina. Resultado: 
Tabela 6.13 Valores absolutos de encargos especiais, em 2014, para o Estado de Santa Catarina e seus Municípios, segundo cálculo que exclui as transferências constitucionais e legais

\begin{tabular}{|c|c|}
\hline REGISTRO & $\begin{array}{c}\text { VALOR } \\
\text { (EM RS) }\end{array}$ \\
\hline $\begin{array}{c}\text { Volume total de transferências destinadas } \\
\text { aos favorecidos situados no Estado }\end{array}$ & $8.268 .139 .036,33$ \\
\hline $\begin{array}{c}\text { Volume total destinado ao Governo do Estado } \\
\text { de Santa Catarina }\end{array}$ & $2.346 .027 .543,65$ \\
\hline $\begin{array}{c}\text { Volume total destinado aos favorecidos } \\
\text { situados nos Municípios do Estado }\end{array}$ & $5.922 .111 .492,68$ \\
\hline
\end{tabular}

Fonte: elaboração própria a partir de BRASIL. Controladoria-Geral da União, cit., p. 247.

c) pesquisa por Consultas Temáticas - Transferências de recursos ou gastos diretos do governo por temas - Transparência nos Estados e Municípios - Estado de Santa Catarina - Transferências por ação Exercício 2014. Resultado:

Tabela 6.14 Transferências de recursos ou gastos diretos do Governo por temas, por ação, em 2014, referentes ao Estado de Santa Catarina

\begin{tabular}{|c|c|c|}
\hline ÁREA & $\begin{array}{c}\text { TOTAL EM DEZEMBRO } \\
(\mathbf{R} \$)\end{array}$ & ACUMULADO NO ANO \\
\hline Todas & $195.991 .906,08$ & $2.346 .027 .543,65$ \\
\hline Encargos especiais & $151.920 .701,51$ & $1.625 .552 .646,17$ \\
\hline Demais transferências & $44.071 .204,51$ & $720.474 .897,48$ \\
\hline
\end{tabular}

Fonte: elaboração própria a partir de BRASIL. Controladoria-Geral da União, cit., p. 247.

d) pesquisa por convênios - Opção por Estado ou Municípios.

$\mathrm{Na}$ realização de pesquisas por convênios, alguns problemas foram imediatamente detectados:

- não foi possível delimitar o período de pesquisa. O programa elenca todos os convênios, celebrados desde 01/01/1996 até a data da pesquisa;

- não foi possível verificar de forma direta os convênios celebrados com os Estados, porque são elencados juntamente com os convênios celebrados com o Município da Capital, dificultando o acesso direto aos convênios celebrados entre a União e o Estado respectivo; 
- são enumerados todos os convênios celebrados, independentemente da natureza jurídica do convenente, se ente federado ou não.

Outras modalidades de pesquisa por convênios também não se mostraram úteis para a delimitação das transferências voluntárias no tocante aos entes da federação. Nesse sentido, tanto a opção a) todos os convênios - que engloba todos os convênios realizados no período de 01/01/1996 até a data corrente, como a opção b) por órgão concedente - que destaca o órgão no contexto da Administração Pública federal, como a opção c) por liberações na semana ou no mês permitem um controle mais atualizado dos ajustes recentemente firmados, mas não são hábeis a embasar a pesquisa das transferências voluntárias.

\subsubsection{O cômputo das transferências por gasto direto por tipo de despesa}

As classificações também se operam por gastos diretos por tipo de despesa, que da mesma forma não se mostram hábeis a identificar a natureza da transferência. Veja-se, por exemplo, o convênio firmado entre a União, por intermédio do Ministério da Cultura, e a Prefeitura de São Paulo:

CLÁUSULA QUARTA - DOS RECURSOS ORÇAMENTÁRIOS E FINANCEIROS

Para a execução das atividades previstas neste CONVÊNIO, no presente exercício dar-se-á o valor de R \$101.032,99 (cento e um mil, trinta e dois reais e noventa e nove centavos) com contrapartida, de acordo com a seguinte informação:

I - CONCEDENTE

$\mathrm{R} \$ 100.000,00$ (cem mil reais) àcontado Projeto/Atividade: 13.392.2027.20ZF.0035, PTRES: 082158, Elemento de Despesa 33.40.41, Nota de Empenho $\mathrm{N}^{\circ}$ 2014NE8000027 de 24/10/2014, Fonte 0100.

\section{II - CONVENENTE}

$\mathrm{R} \$ 1.032,90$ (hum mil, trinta e dois reais e noventa e nove centavos), correspondente à contrapartida do convenente por meio de recursos financeiros. ${ }^{12}$

Verifica-se, outrossim, consoante classificação da Portaria Interministerial n. 163, que o elemento de despesa indicado se refere à categoria de Contribuiçôes (40), o que dificulta a sua identificação como repasse voluntário de recursos.

12 BRASIL. Convênio entre o Município de São Paulo e o Ministério da Cultura n. 812001/2014, de 8 de dezembro de 2014. Diário Oficial da União, Brasília, 9 dez. 2014. Disponível em <https:// www.convenios.gov.br/siconv/ConsultarProposta/ResultadoDaConsultaDeConvenioSelecionarConvenio.do? sequencialConvenio=812001\&Usr=guest\&Pwd=guest $>$. Acesso em 18/12/2015. 


\subsubsection{Outras constatações decorrentes da análise do Portal da Transparência}

Não obstante as inconsistências apontadas, algumas conclusões puderam ser alcançadas mediante a análise dos dados inseridos no Portal da Transparência.

Em primeiro lugar, em Estados mais desenvolvidos, como São Paulo, o volume de recursos recebidos pelas entidades se mostra expressivo se comparado com as transferências diretas aos entes federados. Por outra via, os montantes de transferências diretas aos Estados e Municípios são muito maiores nos Estados mais carentes. A título de exemplo, no caso do Município de Acrelândia, verifica-se que a quase totalidade dos convênios celebrados com a União tem como convenente o Município, sendo poucos os convênios celebrados com associaçôes nele sediadas. Dos 132 convênios celebrados pela União com os beneficiários do Município, apenas 6 não foram ajustados diretamente com o próprio Município de Acrelândia, todos anteriores ao ano de 2002. Situação semelhante ocorre com o Município de São Pedro do Turvo, onde todos os convênios foram celebrados diretamente entre a União e o Município.

\subsubsection{A transparência relativa às transferências voluntárias na esfera estadual}

A ausência de precisão dos dados relativos às transferências voluntárias constitui uma realidade também na esfera estadual, ressaltando-se que a grande maioria dos Estados não disponibiliza informações específicas sobre os repasses de natureza voluntária. Além disso, grande parte deles direciona suas pesquisas relativas a transferências e convênios celebrados com a União ao Portal da Transparência dos Recursos Públicos Federais, não apresentando dados estatísticos específicos relacionados às transferências voluntárias. Ainda que alguns portais apresentem detalhamentos relativos às transferências de recursos recebidas e efetuadas, não se verifica uma caracterização específica dos repasses voluntários.

Por via de regra, os portais de transparência estaduais disponibilizam informações relacionadas aos repasses a Municípios decorrentes apenas de determinação constitucional ou legal. Observa-se também o detalhamento das receitas e dos repasses por convênios com a União, Estados, Municípios e com instituições privadas, mas não a contemplação das transferências voluntárias propriamente ditas. Dados relativos aos convênios celebrados pelos entes federados são bastante recorrentes, mas não há indicativos específicos quanto aos ajustes que veiculam transferências voluntárias na forma prevista no artigo 25 da Lei de Responsabilidade Fiscal. 
Não obstante esse cenário, destacam-se algumas experiências positivas que merecem ser aprimoradas, notadamente verificadas nos Estados do Rio de Janeiro, São Paulo, Ceará e Santa Catarina.

No primeiro caso, o Portal da Transparência do Estado do Rio de Janeiro dispõe de dados bastante claros acerca das transferências voluntárias, constituindo paradigma a ser seguido pelos demais entes federativos e pela própria União. Aponta informações relativas às transferências voluntárias correntes e de capital e, no âmbito de cada uma delas, referências relativas aos repasses direcionados ao SUS, a programas de educação, a programas de assistência social, além das demais transferências da União. Destaca também os repasses e transferências, de caráter voluntário ou não, direcionados aos Municípios do Estado. Além disso, inclui aquelas relacionadas ao Sistema Único de Saúde.

O Portal da Transparência do Estado de São Paulo também disponibiliza informações relacionadas às transferências voluntárias efetuadas pelo Estado, por meio do acesso a informações de convênios. Contudo, as informações não estão classificadas de acordo com o conceito extraído do artigo 25 da Lei de Responsabilidade Fiscal, incluindo também as transferências efetuadas às entidades da sociedade civil. Nesse sentido, conforme informação disponibilizada na página eletrônica estadual:

No Portal da Transparência é possível acessar em primeiro plano as "Transferências Voluntárias" que são repasses de recursos estaduais a Municípios ou pessoas jurídicas da sociedade civil sem fins lucrativos (as chamadas entidades do Terceiro Setor) por meio de convênios firmados ou outro tipo de contrato, para que sejam aplicados na prestação de serviços públicos, na realização de obras e demais tipos de investimentos necessários à ampliação ou melhoria do atendimento à população. Por exemplo: repasse de recursos a um Município para a realização de obras de construção de rede de escoamento de águas pluviais ou repasse de recursos para uma organização social administrar um hospital público do Estado. ${ }^{13}$

No terceiro caso sob destaque, o Portal do Estado do Ceará apresenta números relativos aos "valores transferidos pelo Poder Executivo". Os valores arrecadados por meio de transferências voluntárias pelo Estado são apresentados no link "Receitas do Estado - Recursos Recebidos em Transferências". O Ceará é um dos únicos Estados que apresentam números. Apesar de ser o valor total, sem maiores especificações, trata-se de um avanço no comparativo das transferências. Não aponta outros dados relevantes, como, por exemplo, a origem dos recursos - ainda que grande parte seja proveniente da União -, assim como a finalidade deles.

13 SÃO PAULO (Estado). Transferências de receitas. Portal da Transparência Estadual, São Paulo. Disponível em: <http://www.transparencia.sp. gov.br/transferencias.html>. Acesso em: 17 nov. 2015. 
No último caso, o Portal da Transparência do Estado de Santa Catarina enumera as transferências obrigatórias e voluntárias recebidas da União, com detalhamento das receitas orçadas e arrecadadas. Permite a consulta das transferências mensais ou anual per capita, disponibilizando informaçōes quantitativas relativas às receitas orçada e acumulada.

Em razão da ausência dessas informações nos sites dos demais Estados, foram encaminhados, com base na Lei de Acesso a Informações, requerimentos dirigidos a todas as unidades da federação, objetivando o fornecimento de dados consolidados relativos ao volume de transferências voluntárias recebidas e efetuadas por cada uma das unidades..$^{14} \mathrm{~A}$ resposta ao questionamento não se afastou dos padrões das informações contidas nos respectivos Portais de Transparência Estaduais. A quase totalidade dos entes federados apresentou resposta remetendo as informações sobre o recebimento de transferências voluntárias da União ao Portal de Transparência dos Recursos Públicos federais e, no tocante às transferências efetuadas, apresentou dados relacionados aos convênios celebrados.

Assim, mesmo depois de provocados por um requerimento específico, os entes federados não efetuam uma distinção apropriada quanto às transferências voluntárias propriamente ditas. Inclusive os Estados que não se limitaram ao direcionamento aos respectivos portais, como o Estado de Tocantins, que apresentou planilha contendo todos os convênios celebrados com a União no período de 2010 a 2014, não estabeleceram distinção quanto às transferências voluntárias. Apenas o Estado do Rio Grande do Sul apresentou planilha com dados relativos às transferências pagas e recebidas pelo Estado, com referência expressa às transferências voluntárias, embora sem maiores especificações quanto à natureza.

Percebe-se, dessa forma, a ausência de dados estatísticos específicos sobre o volume das transferências e suas especificações. Não é suficiente, de outra sorte, a demonstração das transferências por meio da apresentação de dados relativos aos convênios, na medida em que os conceitos não se confundem, ainda que os convênios figurem como os principais instrumentos de veiculação das transferências voluntárias de recursos. ${ }^{15}$ Dessa forma, as informações relacionadas às transferências

14 O questionamento encaminhado com base na Lei de Acesso à Informação foi o seguinte: "Gostaria de saber acerca da existência de dados estatísticos específicos sobre as transferências voluntárias efetuadas pela União ou por outro ente federado ao Estado de (nome do Estado), assim como no tocante às transferências da mesma natureza efetuadas pelo Estado.

Os dados se mostram relevantes para o incremento de estudo acerca das transferências voluntárias que desenvolvo em sede de tese de doutorado junto à Universidade de São Paulo.

Grata desde já pela atenção.”

15 Em resposta ao questionamento efetuado, colacionamos as seguintes informaçôes dos Estados-membros: 
nos portais de transparência estaduais não contemplam especificamente a distinção entre transferências obrigatórias e voluntárias, mas apenas a distinção entre correntes e de capital, que não se mostra adequada para efeitos da caracterização das transferências voluntárias.

Ressalta-se, assim, à guisa de sugestão, a necessidade de padronização da classificação das receitas e das despesas para todas as unidades da federação, fazendo-se incluir no rol das classificações título específico destinado às transferências voluntárias.

Quadro 6.16 Respostas dos Estados aos questionamentos feitos com base na Lei de Acesso à Informação

\begin{tabular}{|c|c|c|}
\hline ESTADO & $\begin{array}{l}\text { INFORMAÇÃO RELATIVA ÀS TRANSFERÊNCIAS } \\
\text { RECEBIDAS DA UNIÃO }\end{array}$ & $\begin{array}{l}\text { INFORMAÇÃO RELATIVA ÀS TRANSFERÊNCIAS } \\
\text { EFETUADAS PELO ESTADO }\end{array}$ \\
\hline Piauí & Remete ao Portal da Transparência federal & $\begin{array}{l}\text { Direciona ao Portal da Transparência do Estado, local } \\
\text { onde dispõe de quadro dos convênios celebrados } \\
\text { e suas informações essenciais, sem a distinção das } \\
\text { transferências voluntárias propriamente ditas. }\end{array}$ \\
\hline Espírito Santo & Remete ao Portal da Transparência federal. & $\begin{array}{l}\text { Remete às informações disponibilizadas no site da } \\
\text { transparência do Estado, dispondo de informações } \\
\text { relacionadas aos convênios e transferências realizadas, } \\
\text { sem a distinção das transferências voluntárias } \\
\text { propriamente ditas. }\end{array}$ \\
\hline Santa Catarina & $\begin{array}{l}\text { Remete às informações disponibilizadas no Portal } \\
\text { de Transparência estadual. Veicula os valores das } \\
\text { transferências recebidas da União, mas não atrelada ao } \\
\text { programa correspondente. }\end{array}$ & $\begin{array}{l}\text { Remete às informações disponibilizadas no Portal de } \\
\text { Transparência estadual. Veicula os gastos relacionados } \\
\text { aos convênios e transferências, pontuando cada um } \\
\text { dos ajustes celebrados. }\end{array}$ \\
\hline Bahia & $\begin{array}{l}\text { Apresenta tabela com os valores das transferências } \\
\text { voluntárias recebidas da União, indicando o volume } \\
\text { total de recursos recebidos. }\end{array}$ & \\
\hline Maranhão & Remete ao Portal da Transparência Federal. & $\begin{array}{l}\text { Remete ao Portal da Transparência estadual que } \\
\text { congrega uma série de transferências sem conter, } \\
\text { no entanto, uma classificação específica para } \\
\text { as transferências voluntárias. Exige, assim, um } \\
\text { conhecimento mínimo da matéria para a busca da } \\
\text { transferência requerida no contexto de todas as } \\
\text { despesas e receitas elencadas. }\end{array}$ \\
\hline Pernambuco & $\begin{array}{l}\text { Remete ao Portal da Transparência do Estado, } \\
\text { contemplando informações sobre as receitas, } \\
\text { divididas entre diversas categorias econômicas, sem } \\
\text { especificação das transferências voluntárias. } \\
\text { As informações obtidas são apenas numéricas. }\end{array}$ & $\begin{array}{l}\text { Remete às informações disponibilizadas no Portal de } \\
\text { Transparência estadual. Veicula os gastos relacionados } \\
\text { aos convênios e transferências, pontuando cada um } \\
\text { dos ajustes celebrados. }\end{array}$ \\
\hline Pará & Remete ao Portal da Transparência federal. & $\begin{array}{l}\text { Remete às informações disponibilizadas no site da } \\
\text { transparência do Estado, dispondo de informações } \\
\text { relacionadas aos convênios e transferências realizadas, } \\
\text { sem a distinção das transferências voluntárias } \\
\text { propriamente ditas. }\end{array}$ \\
\hline Tocantins & $\begin{array}{l}\text { Envio de planilha contendo informações sobre todos } \\
\text { os convênios celebrados com a União no período de } \\
2010 \text { a } 2014 \text {. }\end{array}$ & \\
\hline Rio Grande do Sul & $\begin{array}{l}\text { Envio de planilha com dados relativos às transferências } \\
\text { pagas e recebidas pelo Estado. Referência às } \\
\text { transferências voluntárias, sem especificação. }\end{array}$ & \\
\hline Minas Gerais & $\begin{array}{l}\text { Obtenção de relatório dos convênios de entrada de } \\
\text { recursos. }\end{array}$ & \\
\hline
\end{tabular}

Fonte: elaboração própria. 


\subsubsection{A transparência em outros canais de comunicação}

Outro importante canal de transparência relativo às transferências de recursos da União para os entes subnacionais é o Orçamento Brasil, disponibilizado no Portal da Câmara dos Deputados. Ao lado dos diversos dados relativos à execução orçamentária, o portal disponibiliza informações específicas relativas aos convênios decorrentes de emendas parlamentares, classificadas por autor, unidade da federação, partido e ano da Lei Orçamentária. Assim, especificamente no tocante a esses convênios, são fornecidas informações relacionadas ao número da emenda, valor do repasse, valor da contrapartida, valores empenhado e global, número do convênio e proponente. Da mesma maneira, são disponibilizadas informações relativas às transferências efetuadas aos Estados, Municípios e às entidades privadas, sem, no entanto, maior rigor quanto à classificação da natureza das despesas.

As informações relativas às transferências voluntárias também estão disponibilizadas no Portal da Secretaria do Tesouro Nacional. A partir do exercício de 2015, o site passou a apresentar dados consolidados das transferências voluntárias, especialmente no tocante às unidades da Federação e às regiōes geográficas, em razão de proposta elaborada por Grupo de Estudo voltado à classificação das transferências da União. Tal inovação constituiu um grande avanço da Secretaria do Tesouro Nacional na implementação de uma classificação mais transparente e atenta às diversas nuances das transferências discricionárias, que têm, entre suas modalidades, as transferências voluntárias de recursos.

Assim, as informações disponibilizadas pelo Portal da Secretaria do Tesouro Nacional no momento, especificamente relacionadas ao exercício de 2015, mostram-se mais próximas aos objetivos de transparência dos dados relativos aos repasses efetuados pela União. Observa-se que não se trata ainda do modelo ideal, visto que requer avanços especialmente na publicação de dados mais detalhados sobre as transferências efetuadas, mas sem dúvida permite uma visão mais acurada do perfil das transferências voluntárias entre os entes da federação, em razão do fornecimento dos dados consolidados envolvendo as unidades da Federação e as regiōes geográficas.

\subsection{DIFICULDADES ENFRENTADAS NA DELIMITAÇÃO DAS TRANSFERÊNCIAS VOLUNTÁRIAS}

Consoante já apontado, enfrentou-se uma série de dificuldades para o acesso aos dados concernentes às transferências voluntárias de recursos. Com o fim de aprimorar o quadro de divulgação e consolidação dos dados relativos aos repasses intergovernamentais, passa-se a expor as principais dificuldades observadas na delimitação das transferências voluntárias de recursos, consistentes basicamente na ausência: a) de critérios objetivos de definição das transferências voluntárias; b) de 
padronização e fornecimento de elementos que possam uniformizar os programas em todos os instrumentos de busca; c) de precisão dos dados representativos das transferências voluntárias; d) de informaçôes relativas à origem das transferências voluntárias; e e) de dados específicos relativos às transferências voluntárias.

\subsubsection{Conceito de transferências voluntárias: critério por exclusão}

Uma primeira dificuldade enfrentada na delimitação das transferências voluntárias reside em sua própria definição legal. Com efeito, o conceito é construído a partir da exclusão das modalidades de transferências que não a integrariam. Daí a dificuldade prática de sua caracterização.

A definição legal de transferências voluntárias, contida no caput do artigo 25 da LRF, explicita tal caráter ao conceituá-las como "a entrega de recursos correntes ou de capital a outro ente da Federação, a título de cooperação, auxílio ou assistência financeira, que não decorra de determinação constitucional, legal ou os destinados ao Sistema Único de Saúde”. Nesse sentido, conforme aponta José Antonio Meyer:

(...) depreende-se que as Transferências Voluntárias são todas as Transferências Intergovernamentais ocorridas a título de cooperação, auxílio ou assistência de recursos públicos que não decorrerem de determinação constitucional ou legal por repartição de receita tributária. Também as que não decorrerem de determinação constitucional ou legal para a provisão de bens e serviços públicos, inclusive os destinados ao SUS, independentemente de os recursos públicos serem classificados na categoria econômica da despesa como correntes ou de capital. ${ }^{16}$

Assim, sob o aspecto conceitual, merece destaque a classificação atinente ao órgão superior, cuja exclusão incide sobre o Ministério da Saúde, em razão do grande volume de recursos vinculados à pasta, e da clara exceção veiculada pelo artigo 25 da LRF. Especificamente quanto a esse aspecto, o autor pondera:

A exclusão do órgão superior referente ao Ministério da Saúde, quando filtrado conjuntamente com a seleção das modalidades 30 e 40, refere-se às transferências realizadas ao SUS. Se o montante de recursos públicos dotados na LOA Federal ao SUS, especificamente nas modalidades de aplicação - Transferências a estados/DF e a Municípios (códigos 30 e 40 respectivamente) fosse considerado como Transferências Voluntárias, o Ministério da Educação certamente perderia a primeira colocação de Ministério com a maior média de volume de recursos em Transferências Voluntárias.

Além de ser considerado para aprovisionamento de bens e serviços públicos de saúde, a significativa materialidade de recursos que era transferida para atender ao SUS fez com que os legisladores rapidamente o definissem, como uma espécie de transferência de natureza especial, excluindo-a da definição de Voluntárias na LRF. ${ }^{17}$

16 PIRES JÚNIOR, José Antônio Meyer. Transferências voluntárias na caixa de Edgerworth - Sob a égide da Lei de Responsabilidade Fiscal. Brasília: ESAF, 2003.

17 PIRES JÚNIOR, José Antônio Meyer, cit., p. 17. 
É importante observar que, sob o ponto de vista etimológico, os recursos destinados ao SUS poderiam ser considerados transferências voluntárias - assim consideradas a entrega de recursos correntes ou de capital a outro ente da Federação, a título de cooperação, auxílio ou assistência financeira, não decorrente de determinação constitucional ou legal. Contudo, diante do volume de recursos envolvidos e da complexa sistemática de financiamento do Sistema Único de Saúde, optou-se por afastar do conceito os repasses destinados ao SUS, independentemente de sua natureza obrigatória ou voluntária. Da mesma forma, estando as transferências voluntárias sujeitas a algumas condicionantes e vedaçóes, não haveria como impor ao ente federado a sujeição a restrições de repasses relacionados à área da saúde, em virtude da essencialidade do serviço oferecido à população.

Contudo, a exclusão não se limita apenas ao conceito de transferências voluntárias, causando outras implicações. No tocante à classificação das despesas, o caráter de exclusão conferido ao conceito de transferências voluntárias reflete-se no processo de classificação contábil da despesa, que se opera por meio de "filtros". À guisa de exemplo, consoante apontado ainda por Meyer, ao proceder-se à classificação do "grupo de despesa", podem ser utilizados os diversos códigos, exceto o 1, relativo ao grupo “despesas com pagamento de pessoal e encargos”. O mesmo ocorre em relação ao programa, sendo possível a utilização de qualquer código, exceto o 903, relativo às "transferências constitucionais e legais", entre outros critérios. ${ }^{18}$

Resulta daí a necessidade e relevância de se conferir uma uniformização aos critérios de classificação das despesas e receitas resultantes da realização de transferências voluntárias, não se restingindo simplesmente à utilização de codificação não aplicável a outras espécies.

\subsubsection{Ausência de padronização e fornecimento de elementos que possam uniformizar os programas em todos os instrumentos de busca}

Outra constatação refere-se às codificações utilizadas na divulgação dos programas com recursos disponibilizados para as transferências voluntárias. Existe uma aparente disparidade entre a codificação programática utilizada no plano plurianual com os códigos de programas no SICONV, o que gera dificuldades práticas de acesso aos dados. A ausência de padronização dos códigos utilizados e as dificuldades no acesso a elementos que permitam realizar uma efetiva busca demonstram a necessidade de fornecimento de elementos que possam uniformizar os programas em todos os instrumentos de busca.

18 PIRES JÚNIOR, José Antônio Meyer, cit., p. 15. 
Apenas a título exemplificativo, veja-se como paradigma o Programa 2013, constante do Plano Plurianual Federal 2012-2015, veiculado pela Lei Federal n. 12.593, de 18 de janeiro de 2012. Mencionado programa, integrante da relação dos Programas Temáticos inseridos no âmbito do Ministério da Agricultura, Pecuária e Abastecimento, tem como objeto a Agricultura Irrigada, contemplando, por sua vez, uma série de objetivos e iniciativas. Contudo, ao realizar-se busca dos convênios celebrados no âmbito do mencionado programa, incluindo-se o número do programa constante no PPA, a pesquisa não apresentou retorno. Por meio de consulta pelo nome do programa constante no PPA (Agricultura Irrigada) também não apareceram resultados. Apenas pela consulta efetuada no campo "Descrição do Programa", inserindo-se a expressão "agricultura irrigada", a pesquisa apresentou três retornos: 2200020150001; 2200020140016; e 2200020130037, representando 22000 o código do Ministério da Agricultura, seguido do respectivo exercício financeiro.

Observa-se, assim, que o código do programa no SICONV é diverso daquele constante no PPA. Torna-se prudente o estabelecimento de um mecanismo de padronização da codificação que permita, ao menos, diminuir entraves ao acesso e à análise do complexo sistema de transferências e do próprio sistema orçamentário como um todo, constituindo meio facilitador de pesquisas junto ao SICONV.

\subsubsection{Ausência de precisão dos dados representativos das transferências voluntárias}

Os dados fornecidos pela Administração sobre as transferências voluntárias não apresentam contornos precisos, conforme atesta a própria nota explicativa do Relatório sobre as Transferências Voluntárias aos Estados, Distrito Federal e Municípios, elaborado periodicamente pela Secretaria do Tesouro Nacional. O documento aponta para o processo de exclusão de parcelas das transferências constitucionais e legais como forma de se obter o montante das transferências voluntárias, daí advindo a possibilidade de ocorrência de falhas quanto à precisão do volume.

Observa-se que, a fim de se coadunar aos termos da definição legal, o cálculo exclui as transferências que, por sua natureza, seriam classificadas enquanto transferências voluntárias, mas não integram o conceito por exclusão legal, como é o caso das transferências adstritas ao Sistema Único de Saúde (art. 25, caput, da LRF). Nesse sentido, dispóe a nota explicativa:

As informações relativas às Transferências Voluntárias a Estados, Distrito Federal e Municípios resultam da consolidação de empenhos liquidados e registrados no Sistema Integrado de Administração Financeira do Governo Federal - SIAFI, pelos órgãos e entidades da Administração Pública, nas modalidades 30 (transferências aos estados e 
ao Distrito Federal), 31 (transferências fundo a fundo aos estados e ao Distrito Federal), 40 (transferências aos Municípios) e 41 (transferências fundo a fundo aos Municípios). Tal montante é obtido através da subtração das transferências constitucionais e legais (FPE, FPM, FUNDEB, ITR, IOF-ouro, FPEX, Lei Complementar 87/96, Cota-parte do Salário-Educação, Compensações Financeiras), Despesas com Pessoal e decorrentes do Programa de Aceleração do Crescimento - PAC, do valor global das transferências. A informação resultante assim obtida deve ser analisada com certa margem de reserva, pois certos programas que a integram possuem características como legislação própria e um certo viés obrigatório, podendo ser interpretada também como não voluntária, mas seria necessário um estudo mais aprofundado que o ora proposto e talvez outro tipo de classificação das transferências para melhor caracterizá-las.

Para atender à definição de Transferências Voluntárias da Lei de Responsabilidade Fiscal (LC 101/00), a partir de 2000 os recursos do Sistema Único de Saúde também são retirados do cálculo. É importante ressalvar que as transferências para pagamento de pessoal nos Estados e DF não são alvo deste relatório, mesmo que efetuadas através de convênios. Os valores relativos à rubrica Restos a Pagar Não Processados estão discriminados a parte no final do demonstrativo, não foram somados aos quadros anteriores. ${ }^{19}$

Por outro lado, não fica claro se existe distinção entre as instâncias envolvidas nas transferências, isto é, se as informações ficam restritas aos entes da federação, em observância à definição de transferências voluntárias da Lei de Responsabilidade Fiscal, se abrangem outras entidades da Administração indireta do próprio ente ou até mesmo se englobam entidades de natureza privada. Apenas publicações oficiais esparsas consideram a distinção, como, por exemplo, as "Informações Gerenciais de Transferências Voluntárias da União”, de autoria da Secretaria de Logística e Tecnologia da Informação do Ministério do Planejamento, que aborda, em levantamentos separados, as "Informações Gerenciais de Transferências Voluntárias da União para Entidades Privadas Sem Fins Lucrativos". Trata-se de uma prática que deveria ser implementada em outras publicações oficiais relativas ao tema.

Verifica-se, outrossim, que a denominação empregada nas mencionadas informações não realiza a distinção do artigo 25 da Lei de Responsabilidade Fiscal, sendo indistinto o emprego do termo transferências voluntárias tanto para as entidades privadas sem fins lucrativos, quanto para os entes da federação.

Resta, assim, comprometida a construção de um quadro representativo e efetivo das transferências voluntárias no Brasil, salientando-se que o próprio SICONV, não obstante se constitua em um instrumento de operacionalização de transferências voluntárias, congrega dados tanto da Administração direta dos entes federados, quanto da Administração indireta e das entidades da sociedade civil.

19 BRASIL. Secretaria do Tesouro Nacional; Coordenação-Geral de Análise e Informações das Transferências Financeiras Governamentais, cit., p. 238, p. 2. Grifo nosso. 
Dessa forma, faz-se mister a divulgação de dados específicos, por ente federado, relatando o volume de transferências realizadas e recebidas, distinguindo-as das transferências destinadas às entidades da administração indireta e às entidades privadas sem fins lucrativos.

\subsubsection{Ausência de dados relativos à origem das transferências voluntárias}

Outro ponto que chama a atenção diz respeito à ausência de dados sobre a proporção dos repasses por emendas parlamentares em relação à totalidade das transferências voluntárias e, especificamente quanto às emendas, a proporção entre aquelas que destinam recursos a entes da federação e aquelas destinadas às entidades da sociedade civil. Destaca-se, assim, a necessidade de divulgação do volume de transferências decorrentes de emendas parlamentares, até mesmo como forma de fornecimento de quadro geral de atuação parlamentar e das prioridades por eles destacadas.

\subsubsection{Ausência de dados específicos relativos às transferências voluntárias}

Sob o clamor da transparência que rege os atos da Administração Pública, foram desenvolvidos mecanismos relacionados à ampla divulgação dos atos de gestão pública, inclusive dos atos de gestão orçamentária e, por conseguinte, das transferências voluntárias. No entanto, para o conhecimento da real dimensão dos dados a elas relacionados, existem diversas dificuldades, sendo verdadeiramente uma batalha a sua obtenção, haja vista a já apontada ausência de estatísticas disponibilizadas neste sentido. Nessa medida, indaga-se: como calcular o volume de transferências voluntárias recebidas pelos entes federados, diante da indisponibilidade dos dados já filtrados nos respectivos portais de transparência dos entes federados?

A obtenção dos dados envolve um claro esforço por parte do interessado, que deverá proceder a cálculos como forma de aferir o volume, ou o montante aproximado, das transferências voluntárias realizadas. Ainda assim, deverá efetuar nova análise, a fim de aferir se a transferência em análise foi destinada a um ente federado, caracterizando-se assim, a transferência voluntária stricto sensu, nos termos do artigo 25 da LRF, ou a uma entidade de natureza privada situada na respectiva esfera federativa.

$\mathrm{Na}$ busca pelos dados relativos às transferências voluntárias efetuadas pela União aos Estados, parte-se do volume total de transferências, disponibilizado pelo Portal da Transparência, para, posteriormente, abaterem-se os dados relativos às 
transferências constitucionais e legais. ${ }^{20}$ Além disso, enquanto mecanismo auxiliar de aferição do volume de transferências voluntárias da União, merece destaque a classificação de parte das transferências obrigatórias enquanto ENCARGOS ESPECIAIS, na forma definida no glossário disponível no próprio endereço eletrônico do Portal da Transparência:

\section{Encargos Especiais:}

É uma das funções previstas na classificação funcional da despesa. A classificação funcional possui 5 dígitos (XX - FUNÇÃO e XXX - SUBFUNÇÃO). Conforme o Manual Técnico de Orçamento - MTO, a função Encargos Especiais engloba as despesas em relação às quais não se pode associar um bem ou serviço a ser gerado no processo produtivo corrente, tais como: dívidas, ressarcimentos, indenizaçóes e outras afins, representando, portanto, uma agregação neutra. $\mathrm{O}$ termo “Encargos Especiais” também poderá estar associado à subfunção 846 - Outros Encargos Especiais, assim como a Programas, tais como: 0901 - Operaçōes Especiais: Cumprimento De Sentenças Judiciais; 0902 - Operações Especiais: Financiamentos com Retorno; e 0903 - Operaçóes Especiais: Transferências Constitucionais e decorrentes de Legislação Específica. Fonte: CGU. ${ }^{21}$

Com efeito, afere-se, do ponto de vista prático, que o valor obtido a partir da soma das transferências constitucionais e legais (FPE, FPM, FUNDEF, ITR, IOF-ouro, FPEX, Lei Complementar 87/96, Cota-parte do Salário-Educação, Compensações Financeiras e transferências decorrentes dos concursos de prognósticos) corresponde ao valor estipulado a título de Encargos Especiais. Contudo, tal não significa que todas as transferências legais estejam incluídas nesse cálculo. Outros diplomas esparsos e de menor incidência não podem ser descartados, devendo ainda ser considerada a natureza de transferências específicas, como as decorrentes do PAC, que dispõem de natureza obrigatória por força de lei.

20 Conforme exposto no site do SIAFI: “As estatísticas sobre as Transferências Voluntárias são obtidas no Sistema Integrado de Administração Financeira do Governo Federal (SIAFI) do valor global excluídas as transferências constitucionais e legais (FPE, FPM, FUNDEF, ITR, IOF-ouro, FPEX, Lei Complementar n. 87/96, Cota-parte do Salário-Educação, Compensaçôes Financeiras e Despesas com Pessoal).

Não estão incluídos no cálculo os valores relativos à rubrica 'Restos a Pagar Não Processados' e os recursos do Sistema Único de Saúde (SUS).” (BRASIL. Secretaria do Tesouro Nacional. CAUC - Sistema Auxiliar de Informações para Transferências Voluntárias. Portal do SIAFI. Disponível em: <http://www.tesouro.fazenda.gov.br/-/cauc-sistema-auxiliar-de-informacoes-para-transferencias-voluntarias $>$. Acesso em: $1^{\circ}$ abr. 2014).

21 BRASIL. Controladoria-Geral da União. Verbete “Encargos Especiais”. Portal da Transparência nos Recursos Públicos Federais. Disponível em: <http://www.portaldatransparencia.gov.br/ glossario/DetalheGlossario.asp?letra=e>. Acesso em: 26 abr. 2015. Grifo nosso. 


\subsubsection{Relatório de Atividades do Subgrupo de Trabalho Classificação das Transferências da União}

Em razão das incongruências e dificuldades apontadas, com base na constituição do Grupo de Trabalho "Transferências da União", da Casa Civil da Presidência da República, foi formado o Subgrupo de Trabalho "Classificação das Transferências da União", com a finalidade de apresentação de proposta de classificação das transferências fiscais do governo federal. Conforme extraído do relatório apresentado pelo Subgrupo:

(...) considerou-se oportuno criar um quadro estruturado e sistematizado da execução das transferências fiscais no Brasil, a fim de proporcionar uma visão global do assunto e, dessa forma, auxiliar na compreensão do mesmo. A forma encontrada para isso foi elaborar uma classificação ordenada e sintetizada das transferências fiscais vigentes no país. ${ }^{22}$

Como decorrência dos estudos realizados, a Comissão propôs uma classificação das transferências fiscais daquele ente em duas categorias principais: obrigatórias, de natureza constitucional ou legal, e discricionárias, condicionadas à celebração de instrumento jurídico próprio entre as partes.

As transferências discricionárias, que nos interessam mais de perto, comportariam as seguintes subdivisões:

[a) Voluntárias] São aquelas que efetuam a entrega de recursos para Entes Federativos a título de cooperação, auxílio ou assistência financeira, que não decorrem de determinação constitucional ou legal, nem sejam destinados ao Sistema Único de Saúde. Elas exigem a celebração de um instrumento jurídico entre as partes envolvidas e, regra geral, requerem contrapartida financeira do beneficiário.

[b) Para organizaçóes da sociedade civil] São aquelas efetuadas pela administração pública para organizaçōes da sociedade civil sem fins lucrativos a título de subvenção, auxílio e contribuição, visando a consecução de finalidades de interesse público. Elas exigem a celebração de um instrumento jurídico entre as partes envolvidas.

[c) Por delegação] São aquelas efetuadas entre Entes Federativos ou a consórcios públicos visando a execução descentralizada de projetos e açôes públicas de responsabilidade exclusiva do concedente e exigem a celebração de um instrumento jurídico entre as partes envolvidas.

[d) Específicas] São aquelas cujo atendimento de requisitos fiscais pelo beneficiário é dispensado por lei, e normalmente estão relacionadas a programas essenciais de

22 BRASIL. Casa Civil; Subgrupo de Trabalho Classificação das Transferências da União. Relatório de atividades. Brasília: Subgrupo de Trabalho Classificação das Transferências da União, 2015. Disponível em: <http://www.tesouro.fazenda.gov.br/documents/10180/333563/pge_ relatorio_class_transf.pdf>. Acesso em: 18 dez. 2015, p. 3. 
governo. Elas exigem a celebração de um instrumento jurídico entre as partes envolvidas, e a sua execução orçamentária tem caráter discricionário, apesar de algumas delas serem definidas como transferências obrigatórias ou automáticas por intermédio de leis específicas. ${ }^{23}$

Verifica-se que a classificação proposta acaba por revelar um quadro mais próximo à realidade das transferências voluntárias propriamente ditas, como definidas pelo artigo 25 da Lei de Responsabilidade Fiscal.

As informações veiculadas pela Secretaria do Tesouro Nacional, anteriormente denominadas "Transferências Voluntárias e Estados, DF e Municípios", passaram a denominar-se "Transferências Discricionárias a Estados, DF e Municípios" a partir de junho de 2015, já com a adoção da classificação proposta. Anteriormente, o próprio texto apontava para a falta de clareza dos dados nele constantes:

Este demonstrativo divulga o montante dos recursos financeiros transferidos pela União para os Estados, Distrito Federal e Municípios em decorrência da celebração de convênios, acordos, ajustes ou outros instrumentos similares.

As informações relativas às Transferências Voluntárias a Estados, Distrito Federal e Municípios resultam da consolidação de empenhos liquidados e registrados no Sistema Integrado de Administração Financeira do Governo Federal - SIAFI, pelos órgãos e entidades da Administração Pública, nas modalidades 30 (transferências aos estados e ao Distrito Federal), 31 (transferências fundo a fundo aos estados e ao Distrito Federal), 40 (transferências aos Municípios) e 41 (transferências fundo a fundo aos Municípios). Tal montante é obtido através da subtração das transferências constitucionais e legais (FPE, FPM, FUNDEB, ITR, IOF-ouro, FPEX, Lei Complemen$\operatorname{tar}$ 87/96, Cota-parte do Salário-Educação, Compensações Financeiras), Despesas com Pessoal e decorrentes do Programa de Aceleração do Crescimento - PAC, do valor global das transferências. A informação resultante assim obtida deve ser analisada com certa margem de reserva, pois certos programas que a integram possuem características como legislação própria e um certo viés obrigatório, podendo ser interpretada também como não voluntária, mas seria necessário um estudo mais aprofundado que o ora proposto e talvez outro tipo de classificaçáo das transferências para melhor caracterizá-las.

Para atender à definição de Transferências Voluntárias da Lei de Responsabilidade Fiscal (LC 101/00), a partir de 2000 os recursos do Sistema Único de Saúde também são retirados do cálculo. É importante ressalvar que as transferências para pagamento de pessoal nos Estados e DF não são alvo deste relatório, mesmo que efetuadas através de convênios. Os valores relativos à rubrica Restos a Pagar Não Processados estão discriminados a parte no final do demonstrativo, não foram somados aos quadros anteriores. ${ }^{24}$

23 BRASIL. Casa Civil; Subgrupo de Trabalho Classificação das Transferências da União, cit., p. 5.

24 BRASIL. Secretaria do Tesouro Nacional; Coordenação-Geral de Análise e Informações das Transferências Financeiras Governamentais, cit., p. 238, p. 1. Grifo nosso. 
A proposta foi apresentada à Subsecretaria de Relações Financeiras Intergovernamentais da Secretaria do Tesouro Nacional pela Nota Técnica n. 14/2015/ COINT/SURIN/STN/MF-DF, sugerindo "a publicação dos dados relativos às transferências discricionárias no site da Secretaria do Tesouro Nacional, juntamente com o relatório do grupo de trabalho, como consulta pública pelo período de 45 dias de forma a coletar contribuiçóes dos usuários", sendo que "ao final desse prazo, as propostas serão avaliadas e as acatadas serão inseridas nas estatísticas que devem continuar disponibilizadas no site". ${ }^{25}$ Foi sugerida, ainda, a consulta à "Coordenação-Geral de Normas de Contabilidade Aplicadas à Federação - CCONF - para que se avalie a possibilidade de inserção da tipologia desenvolvida pelo grupo de trabalho nos manuais de contabilidade aplicados ao setor público, assim como as medidas necessárias para isso". ${ }^{26}$

Buscou-se, assim, a correção de importante distorção verificada na transparência dos dados relativos às transferências de recursos por meio de uma precisa delimitação das transferências voluntárias propriamente ditas em relação às demais transferências cujo vínculo seja estabelecido por instrumento jurídico próprio, mas não sejam decorrentes de imposição constitucional ou legal. Embora se trate de proposta passível de ajustes e melhorias, o modelo fornece um panorama mais claro do perfil das transferências voluntárias celebradas entre os entes da federação, mediante o fornecimento de dados consolidados em consonância com a definição veiculada pelo artigo 25 da Lei de Responsabilidade Fiscal, podendo servir como importante referência para a implantação por outras unidades da federação. Requer, no entanto, avanços especialmente na publicação de dados mais detalhados sobre as transferências efetuadas, como, por exemplo, no tocante à origem e destinação específicas dos repasses.

\subsection{FINALIDADES DAS TRANSFERÊNCIAS VOLUNTÁRIAS}

Quanto às finalidades dos repasses, as transferências voluntárias estariam destinadas, em tese, à realização de despesas relacionadas ao desenvolvimento do ente federado,

25 BRASIL. Ministério da Fazenda; Secretaria do Tesouro Nacional; Subsecretaria de Relaçôes Financeiras Intergovernamentais; Coordenação-Geral de Análise e Informações das Transferências Financeiras Intergovernamentais. Nota Técnica n. 14/2015/COINT/SURIN/STN/MF-DF, de 7 de julho de 2015. Brasília: Subsecretaria de Relaçōes Financeiras Intergovernamentais, p. 3.

26 BRASIL. Ministério da Fazenda; Secretaria do Tesouro Nacional; Subsecretaria de Relações Financeiras Intergovernamentais; Coordenação-Geral de Análise e Informações das Transferências Financeiras Intergovernamentais. Nota Técnica n. 14/2015/COINT/SURIN/STN/MF-DF, de 7 de julho de 2015. Brasília: Subsecretaria de Relações Financeiras Intergovernamentais, p. 3. 
ao contrário dos recursos próprios e dos decorrentes de transferências obrigatórias, destinados à realização das despesas correntes. No entanto, o que se observa na prática é o grande volume de repasses empregados para a consecução de obrigaçôes ínsitas ao ente federado, e não despesas com investimentos ou mesmo inversões financeiras.

Observa-se, no entanto, um perfil diferenciado relativamente às finalidades dos repasses de acordo com o nível de desenvolvimento do ente destinatário das transferências voluntárias. Assim, os principais objetivos que norteiam os ajustes envolvendo os Municípios com IDH mais baixo estão relacionadas às condições básicas de infraestrutura social, especialmente construção de moradias, melhoria de condições de habitabilidade e sanitárias domiciliares, tratamento e destinação dos resíduos sólidos, construção de pontes, recuperação de estradas, contribuição suplementar para a manutenção e desenvolvimento do ensino fundamental em escolas municipais, execução de sistema de abastecimento de água, construção de unidades de saúde, aprimoramento do ensino, pavimentação de ruas, aquisição de mobiliário para escolas. Verifica-se, ainda, alguns objetivos relacionados à aquisição de máquinas e equipamentos agrícolas, aquisição de veículos, construção e reforma de prédios públicos, quadras de esportes e ginásios.

A análise das finalidades das transferências voluntárias destinadas aos Municípios com IDH mais elevado, por seu turno, evidencia um quadro com algumas alterações, sendo que as principais finalidades encontradas, além do grande número de ações voltadas à construção e melhorias de unidades especializadas e centros de saúde, são voltadas a ações de infraestrutura urbana, programas de inclusão social, cursos de capacitação, programas de incremento ao turismo, apoio à realização de seminários e exposições, revitalização de museus, serviços de proteção sócio-assistencial, reabilitação e reforma de parques públicos, programas de formação e qualificação profissional, incentivo às práticas desportivas, construção e reformas de ginásios poliesportivos, recapeamento de vias, oferecimento de cursos de pós-graduação, fomento ao desenvolvimento de pesquisas tecnológicas e na área da saúde, prevenção e combate a doenças endêmicas ou não, realização de eventos esportivos, desenvolvimento de programas de apoio tecnológico, aquisição de veículos para transporte escolar, especialmente para estudantes com necessidades especiais ou residentes na zona rural.

Nesse sentido, ao analisar os dados fornecidos pela Controladoria-Geral da União, relativos aos convênios celebrados pela União com os Municípios no período compreendido entre 1996 e 2008, Fabrício Gallo constata:

(...) se nos atentarmos para os convênios firmados pelos Ministérios da Ciência e Tecnologia e o das Comunicaçôes, percebemos que somente 863 e 283 Municípios 
firmaram convênios com os referidos ministérios, respectivamente. Partindo dessa observação podemos inferir que os investimentos que visam a implementação de infra-estruturas de modernização do território brasileiro destinam-se majoritariamente a Municípios que são parte da Região Concentrada (SANTOS, 1996) do país (e a alguns poucos das demais regiōes) e que possuem, em sua maioria, uma elevada densidade técnica e informacional (SANTOS, 2002). Se somarmos os valores de recursos destinados aos Municípios dos estados de SP, RJ, ES, MG, PR, SC e RS o resultado é de aproximadamente $\mathrm{R} \$$ 4,7 bilhões, enquanto que somados recursos destinados aos Municípios de todos os outros estados (BA, SE, AL, PE, PB, RN, CE, PI, MA, AM, $\mathrm{PA}, \mathrm{TO}, \mathrm{RO}, \mathrm{RR}, \mathrm{AC}$ e MT) seria R \$ 1,4 bilhôes. $^{27}$

Em síntese, a diferença essencial entre ambas as realidades reside na destinação de recursos para finalidades básicas da população como moradia, alimentação, transporte e saneamento básico, nos Municípios mais pobres, ao passo que nos Municípios mais desenvolvidos também são privilegiados programas relacionados à infraestrutura urbana, açôes culturais, aperfeiçoamento profissional, desenvolvimento tecnológico, fomento aos esportes, entre outros aspectos.

Feitas as considerações relacionadas às finalidades dos convênios e aos contratos de repasse, seria de extrema utilidade, na publicação dos dados relativos às transferências voluntárias, a realização e divulgação de estatísticas, por ente federado, relativas à destinação e ao emprego dos recursos objeto de transferência, com vistas ao efetivo conhecimento da realidade de cada ente federativo. Isso também evidenciaria a capacidade ou incapacidade desses entes para arcar com os custos essenciais de um membro da federação e com o atendimento das necessidades básicas de sua população, o que, como visto, tem reflexos diretos no modelo de federalismo existente em nosso país, haja vista a correlação da abordagem com a questão da autonomia dos entes federados. Tal medida se mostra relevante para o aprimoramento do modelo de federalismo existente em nosso país e para a busca de medidas que tornem mais efetivos os gastos públicos com vistas ao bem-estar da população e ao desenvolvimento social e econômico do país.

Observa-se, ainda, em muitos casos, que o convênio ou o contrato de repasse não se encontra disponibilizado para consulta, havendo apenas a divulgação de extratos contendo os dados básicos da celebração sem a integralidade de seus termos. Isso dificulta sobremaneira a realização de um efetivo controle dos atos administrativos, assim como a própria aferição do objeto conveniado por meio de seus

27 GALLO, Fabrício. Território nacional e pacto federativo brasileiro: uma análise geográfica das transferências de recursos entre os entes federados. In: XII EGAL - ENCUENTRO DE GEÓGRAFOS DE AMÉRICA LATINA, 2009, Montevideo. Anais do XII EGAL - Encuentro de geógrafos de América Latina, 2009. 
contornos precisos. No tocante aos contratos de repasse, observa-se a dificuldade de acesso aos termos integrais dos ajustes celebrados com intermediação financeira da Caixa Econômica Federal (CEF), na medida em que, ao se efetivar a pesquisa junto ao Portal dos Convênios, o usuário é direcionado ao endereço eletrônico da CEF para obter essas informações. Contudo, ao se proceder à pesquisa junto ao portal da instituição, o resultado reverte apenas o extrato do contrato de repasse, não os seus efetivos termos, em contrariedade aos princípios elementares da Administração Pública, especialmente os princípios da publicidade e transparência.

Ainda, a própria página do Portal da Transparência federal, em alguns casos, orienta o interessado na busca de informaçôes sobre a gestão do convênio a recorrer ao órgão concedente para a obtenção de informações, nos seguintes termos:

\section{Perguntas Frequentes - Convênios}

Conheço o Portal da Transparência, fiz download da planilha de convênios, mas gostaria de obter mais detalhes sobre um convênio, como detalhamento do objeto ou prestação de contas?

Para informações sobre a gestão deste convênio, entre em contato com o Órgão Concedente, ou seja, com o órgão da administração pública federal direta, autárquica ou fundacional, empresa pública ou sociedade de economia mista, responsável pela transferência dos recursos financeiros ou pela descentralização dos créditos orçamentários destinados à execução do objeto do convênio.

Nessa medida, buscando dar efetividade ao princípio da transparência, sobressai a obrigatoriedade da divulgação dos termos integrais dos ajustes celebrados, assim como a disponibilidade de meios facilitadores do acesso à integralidade das informações.

\subsubsection{As transferências destinadas ao Sistema Único de Saúde}

No âmbito da União, o Ministério da Saúde figura como o órgão com o maior volume de recursos disponibilizados em transferências a outros entes da federação e entidades de natureza privada. Contudo, as transferências efetuadas pelo Ministério da Saúde não podem ser classificadas enquanto transferências voluntárias, em virtude de expressa restrição contida no artigo 25, caput, da Lei de Responsabilidade Fiscal. ${ }^{28}$ Assim, as transferências destinadas ao Sistema Único de Saúde (SUS) são classificadas separadamente por conta da relevância do assunto. Tais operações são realizadas por meio da celebração de convênios, de contratos de

28 Dispõe o art. 25 da LRF: Para efeito desta Lei Complementar, entende-se por transferência voluntária a entrega de recursos correntes ou de capital a outro ente da Federação, a título de cooperação, auxílio ou assistência financeira, que não decorra de determinação constitucional, legal ou os destinados ao Sistema Único de Saúde. 
repasses e, principalmente, das chamadas transferências fundo a fundo, onde os valores são transferidos diretamente do Fundo Nacional de Saúde aos fundos de saúde estaduais, municipais e do Distrito Federal. Os depósitos são feitos em contas individualizadas, isto é, específicas dos fundos.

O Sistema Único de Saúde, com assento constitucional, é regulado pela Lei Federal n. 8.080, de 19 de setembro de 1990, que, ao dispor sobre as condições para a promoção, proteção e recuperação da saúde e a organização e o funcionamento dos serviços correspondentes, define o sistema enquanto "o conjunto de ações e serviços de saúde, prestados por órgãos e instituiçõos públicas federais, estaduais e municipais, da Administração direta e indireta e das fundações mantidas pelo Poder Público" (art. 4º caput). Sem embargo, o artigo 199 da Constituição Federal prevê a possibilidade de participação das instituições privadas, preferencialmente as entidades filantrópicas e as sem fins lucrativos, em caráter complementar do Sistema Único de Saúde. ${ }^{29}$

Os recursos destinados ao Sistema Único de Saúde dispõem de normatização e gestão próprias, contando, inclusive, com um orçamento em apartado do Orçamento Fiscal, na esteira do disposto nos artigos $165, \$ 5^{\circ}$ e $198, \$ 1^{\circ}$ da CF:

Art. 165. Leis de iniciativa do Poder Executivo estabelecerão:

I - o plano plurianual;

II - as diretrizes orçamentárias;

III - os orçamentos anuais.

(..)

$\$ 5^{\circ}$ A lei orçamentária anual compreenderá:

I - o orçamento fiscal referente aos Poderes da União, seus fundos, órgãos e entidades da administração direta e indireta, inclusive fundações instituídas e mantidas pelo Poder Público;

29 Dispõem o caput e os parágrafos do art. 199: Art. 199. A assistência à saúde é livre à iniciativa privada.

$\$ 1^{\circ}$ As instituições privadas poderão participar de forma complementar do sistema único de saúde, segundo diretrizes deste, mediante contrato de direito público ou convênio, tendo preferência as entidades filantrópicas e as sem fins lucrativos.

$\$ 2^{\circ}$ É vedada a destinação de recursos públicos para auxílios ou subvenções às instituições privadas com fins lucrativos.

$\$ 3^{\circ}$ É vedada a participação direta ou indireta de empresas ou capitais estrangeiros na assistência à saúde no País, salvo nos casos previstos em lei.

$\$ 4^{\circ}$ A lei disporá sobre as condições e os requisitos que facilitem a remoção de órgãos, tecidos e substâncias humanas para fins de transplante, pesquisa e tratamento, bem como a coleta, processamento e transfusão de sangue e seus derivados, sendo vedado todo tipo de comercialização. 
II - o orçamento de investimento das empresas em que a União, direta ou indiretamente, detenha a maioria do capital social com direito a voto;

III - o orçamento da seguridade social, abrangendo todas as entidades e órgãos a ela vinculados, da administração direta ou indireta, bem como os fundos e fundações instituídos e mantidos pelo Poder Público.

(...)

Art. 198. As ações e serviços públicos de saúde integram uma rede regionalizada e hierarquizada e constituem um sistema único, organizado de acordo com as seguintes diretrizes:

\section{(...)}

$\$ 1^{\circ} \mathrm{O}$ sistema único de saúde será financiado, nos termos do art. 195, com recursos do orçamento da seguridade social, da União, dos Estados, do Distrito Federal e dos Municípios, além de outras fontes. (Grifo nosso)

No nível infraconstitucional, a gestão dos recursos financeiros do Sistema Único de Saúde é objeto de disciplina específica, constante do artigo 33 da Lei Federal n. 8.080/1990...$^{30}$

30 Dispõem os arts. 33 a 35 da lei: Art. 33. Os recursos financeiros do Sistema Único de Saúde (SUS) serão depositados em conta especial, em cada esfera de sua atuação, e movimentados sob fiscalização dos respectivos Conselhos de Saúde.

$\$ 1^{\circ} \mathrm{Na}$ esfera federal, os recursos financeiros, originários do Orçamento da Seguridade Social, de outros Orçamentos da União, além de outras fontes, serão administrados pelo Ministério da Saúde, através do Fundo Nacional de Saúde;

$\$ 2^{\circ}$ (Vetado);

$\$ 3^{\circ}$ (Vetado);

$\$ 4^{\circ}$ O Ministério da Saúde acompanhará, através de seu sistema de auditoria, a conformidade à programação aprovada da aplicação dos recursos repassados a Estados e Municípios. Constatada a malversação, desvio ou não aplicação dos recursos, caberá ao Ministério da Saúde aplicar as medidas previstas em lei.

Art. 34. As autoridades responsáveis pela distribuição da receita efetivamente arrecadada transferirão automaticamente ao Fundo Nacional de Saúde (FNS), observado o critério do parágrafo único deste artigo, os recursos financeiros correspondentes às dotações consignadas no Orçamento da Seguridade Social, a projetos e atividades a serem executados no âmbito do Sistema Único de Saúde (SUS).

Parágrafo único. Na distribuição dos recursos financeiros da Seguridade Social será observada a mesma proporção da despesa prevista de cada área, no Orçamento da Seguridade Social. Art. 35. Para o estabelecimento de valores a serem transferidos a Estados, Distrito Federal e Municípios, será utilizada a combinação dos seguintes critérios, segundo análise técnica de programas e projetos:

I - perfil demográfico da região; 
Não obstante as transferências intergovernamentais destinadas ao Sistema Único de Saúde ocupem posição de destaque em quase todos os entes federados, sendo a saúde, em regra, a área que recebe o maior volume de recursos por essa via, tais transferências não são, por força legal, classificadas como transferências voluntárias, mesmo que sua realização não seja decorrente de determinação constitucional ou legal. Assim, embora disponham de características semelhantes às transferências voluntárias efetuadas nas demais áreas, como educação, infraestrutura e segurança pública, elas apresentam status jurídico diferenciado.

O principal efeito dessa diferenciação é o afastamento das transferências destinadas ao Sistema Único de Saúde das restrições e condicionantes legais impostos às transferências voluntárias, analisados em tópico específico. Nessa medida, o legislador optou por blindá-las e não as deixar à mercê de contingências políticas, sociais e econômicas, elevando a saúde a um patamar acima dos demais direitos e das garantias fundamentais albergados pelo texto constitucional.

Importa também mencionar o afastamento da obrigação dos Municípios em apresentar Certidão Negativa de Débito (CND) para o recebimento de recursos, exigida nas contratações com o Poder Público ou no recebimento de benefícios fiscais ou creditícios, quando os valores se destinarem a ações de saúde, assistência social e educação ou em caso de calamidade pública, consoante dispõe o artigo 47, $\$ 6^{\circ}, d$ da Lei Federal n. 8.212/91. Nota-se, ainda, a exceção contemplada pela Portaria Interministerial n. 507/2011, no sentido de que "para fins da aplicação das sanções de suspensão de transferências voluntárias constantes da Lei Complementar n. 101, de 2000, excetuam-se aquelas relativas a ações de educação, saúde e assistência social" (art. 38, $\$ 8^{\circ}$ ).

II - perfil epidemiológico da população a ser coberta;

III - características quantitativas e qualitativas da rede de saúde na área;

IV - desempenho técnico, econômico e financeiro no período anterior;

$\mathrm{V}$ - níveis de participação do setor saúde nos orçamentos estaduais e municipais;

VI - previsão do plano qüinqüenal de investimentos da rede;

VII - ressarcimento do atendimento a serviços prestados para outras esferas de governo.

$\$ 2^{\circ}$ Nos casos de Estados e Municípios sujeitos a notório processo de migração, os critérios demográficos mencionados nesta lei serão ponderados por outros indicadores de crescimento populacional, em especial o número de eleitores registrados;

$\$ 3^{\circ}$ (Vetado);

$\$ 4^{\circ}$ (Vetado);

$\$ 5^{\circ}$ (Vetado);

$\$ 6^{\circ} \mathrm{O}$ disposto no parágrafo anterior não prejudica a atuação dos órgãos de controle interno e externo e nem a aplicação de penalidades previstas em lei, em caso de irregularidades verificadas na gestão dos recursos transferidos. 


\subsection{CPI DAS AMBULÂNCIAS: SUGESTÕES APLICÁVEIS ÀS TRANSFERÊNCIAS VOLUNTÁRIAS}

A Comissão Parlamentar de Inquérito (CPI) das Ambulâncias, do ano de 2006, trouxe à tona uma série de vicissitudes do sistema das transferências voluntárias, especialmente aquelas decorrentes de emendas parlamentares que tenham por objeto a destinação de recursos a entidades da sociedade civil.

Trata-se de Comissão Parlamentar Mista de Inquérito, integrada tanto por membros da Câmara dos Deputados como do Senado Federal, também conhecida por CPMI das Sanguessugas, que teve por objeto a apuração de denúncias envolvendo a "Operação Sanguessuga", realizada pela Polícia Federal, para investigar quadrilha que atuava na aquisição fraudulenta de insumos estratégicos para a saúde.

Embora o cerne do problema abordado pela CPI das Ambulâncias dissesse respeito às fraudes constatadas em transferências voluntárias inseridas por meio de emendas parlamentares destinadas a entidades da sociedade civil, as conclusões e sugestões finais ali alcançadas apresentam pontos de convergência com as transferências de recursos efetuadas entre os entes da federação, razão pela qual se torna pertinente a sua análise.

O relatório final aprovado pela Comissão concluiu que o cenário político, eleitoral e partidário nacional contribui para a existência de distorções e práticas lesivas, consoante se verifica da leitura do seguinte trecho destacado:

Numa situação em que o orçamento tem o caráter de uma autorização de gasto para o Poder Executivo, Deputados e Senadores acrescentam uma série de emendas à lei orçamentária. Por quê algumas dessas emendas são aceitas e incorporadas e outras não? Sabemos todos que a liberação de emendas é um dos mecanismos de manutenção e promoção da maioria de que o governo necessita, numa situação de partidos fracos, no sentido da capacidade pequena de assegurar o voto de suas bancadas. ${ }^{31}$

\subsubsection{Critérios de escolha das emendas}

O relatório ressalta a discussão relativa aos critérios de escolha das emendas parlamentares com vistas à execução dos repasses por elas autorizados. Embora a discussão tenha sido prejudicada com a instituição das emendas de execução obrigatória, ainda assim persiste a indagação acerca de quais os critérios que devem ser empregados para a liberação e acolhimento de algumas demandas por recursos em detrimento de outras.

31 BRASIL. Congresso Nacional, Comissão Parlamentar Mista de Inquérito "das Ambulâncias”. Relatório dos Trabalhos da CPMI "das Ambulâncias" (criada por meio do Requerimento n. 77/2006-CN), v. 2. Brasília: Congresso Nacional, 2006, p. 407. 
Nessa medida, caso considerada a mera discricionariedade, caracterizada pelo alinhamento das opções do administrador com o seu plano de governo, fica clara a legitimidade, ao menos aparente, de suas escolhas, não havendo campo para contestações. Mas e se os critérios forem eminentemente de cunho político-partidário ou eleitoral? A opção permaneceria legítima? A resposta nos parece ser negativa.

A atuação administrativa, ainda que sob a ótica da discricionariedade, deve ser pautada por uma série de princípios que visam a legitimar as opções decorrentes do exercício da discricionariedade. Dessa maneira, restando nítido o caráter meramente político-eleitoral da execução de determinada despesa orçamentária, deve responder o administrador pela má-gestão dos recursos públicos e pelo uso do aparelhamento estatal para benefício próprio. Trata-se de hipótese de desvio de poder, que consiste no uso de um meio legítimo para a obtenção de finalidades diversas ao interesse público.

Em certas situações, a comprovação de eventual desvio de poder é tarefa bastante dificultosa, principalmente quando os objetivos pretendidos coadunam-se com o interesse público, mas em situações em que o descompasso pode ser aferido objetivamente, medidas devem ser adotadas visando coibir a prática. Com efeito, ainda que tenha sido conferida margem de discricionariedade ao administrador, especialmente sob o regime anterior ao das emendas de execução obrigatória, permitindo-se que seja efetuada determinada despesa em detrimento de outra, não se pode permitir que o móvel das escolhas seja prioritariamente destinado a finalidades diversas ao atendimento do interesse público.

\subsubsection{Ausência de critérios de diferenciação quanto à origem das transferências}

Outro ponto importante destacado pela Comissão refere-se à ausência de critérios de diferenciação nos registros das transferências voluntárias. Aponta o relatório que, não obstante as transferências voluntárias de recursos pudessem decorrer a) da apresentação de emendas orçamentárias pelos parlamentares, b) de propostas ou projetos pelos entes interessados, ou c) de iniciativa governamental, ao ser detectada a existência de necessidades ou ao se chegar ao fim da implementação dos programas, os registros das transferências eram realizados sem um padrão adequado, ante a ausência de uma definição contábil de transferência voluntária.

Embora já se tenham passado diversos anos da realização da CPI, algumas constatações e conclusões permanecem atuais. Com efeito, não há uniformidade de critérios objetivos de classificação das diversas modalidades de transferências voluntárias. Não há tampouco uma definição contábil que permita o registro de suas ocorrências de 
forma mais próxima à realidade, de modo a tornar mais claros os dados relativos aos repasses de recursos e facilitar o acesso a tais informaçóes pelos interessados, em prejuízo, ainda, do controle das transferências realizadas. A iniciativa da Secretaria do Tesouro Nacional de implantar um novo modelo de classificação das transferências discricionárias é bastante recente, e as respectivas informações ainda carecem do detalhamento apropriado. Os repositórios disponibilizados também não apresentam claramente a origem das transferências efetuadas, não havendo dados objetivos nem tampouco critérios de busca que permitam identificar se as transferências decorrem de emendas, de iniciativa do concedente ou de apresentação de proposta pelo convenente.

Nesse sentido, posicionou-se o relatório da CPI das ambulâncias:

(...) Assim, o primeiro desafio a ser superado passa pela necessidade de definição conceitual de transferências voluntárias e consequentes adaptações na sistemática de registro contábil. Nesse sentido, esta questão deverá ser objeto de análise conjunta da Secretaria do Tesouro Nacional, Ministério do Planejamento e Orçamento e Tribunal de Contas da União, com o propósito de que se estabeleçam critérios e procedimentos que possibilitem a conceituação e a totalização dos dados relativos a transferências voluntárias, por modalidade, e, adicionalmente, sua vinculação a emendas parlamentares. (...). ${ }^{32}$

Observa-se, dessa forma, que, embora se tenha avançado na publicidade dos dados concernentes às transferências voluntárias, particularmente em virtude dos reclamos da transparência, e no aprimoramento dos registros por conta da instituição do SICONV, a conclusão alcançada pela CPI ainda se aplica na identificação de barreiras a serem superadas para a plena definição dos contornos dessas operações no quadro das finanças públicas. O relatório também salienta a questão da efetividade do controle e acompanhamento das emendas. Nesse sentido, aponta:

Existem alguns óbices à totalização dos quantitativos de emendas parlamentares e convênios a elas vinculados. Na verdade, o SIAFI, sistema que gerencia a execução orçamentária, não estabelece com clareza a vinculação entre determinado gasto e sua origem em emenda parlamentar. Assim, todo o esforço para se realizar a quantificação dos valores envolvidos na destinação de emendas parlamentares fica comprometido pela ausência de controles adequados para tal. A despeito desse fato, alguns dados trazem-nos informações relevantes para o trabalho que ora se faz. ${ }^{33}$

E prossegue na análise das dificuldades relacionadas ao tema:

Relativamente às emendas parlamentares, há outros obstáculos que dificultam a sua quantificação mais precisa. Em primeiro lugar, porque, como já se disse, não existe

32 BRASIL. Congresso Nacional, Comissão Parlamentar Mista de Inquérito "das Ambulâncias", cit., p. 418.

33 BRASIL. Congresso Nacional, Comissão Parlamentar Mista de Inquérito "das Ambulâncias", cit., p. 419. 
vinculação entre a emenda e a sua execução, no SIAFI. Em segundo lugar, porque a definição genérica do objeto da emenda permite que na sua execução, os recursos sejam destinados a objeto não especificado originalmente no texto da emenda, não havendo registro posterior dessa mudança. ${ }^{34}$

Essa situação propicia o desenvolvimento de sistemas paralelos e privados de controle, que acabam sendo oferecidos à aquisição pelas diversas esferas da Administração Pública. A título ilustrativo, segue portfólio de uma das soluçôes desenvolvidas no campo empresarial:

Controle de Emendas Parlamentares

O controle de emendas Parlamentares permite ao Gestor Público efetuar o controle das emendas que afetam o orçamento da instituição. Esta solução opera desde a chegada das emendas da Câmara dos Deputados até a liberação do empenho pela SPOA e envio das informações para execução, seja pelo próprio órgão executor, ou por terceiros (como a CEF, por exemplo). Após esse envio, os saldos no SIAFI são avaliados para avaliar se o empenho da emenda foi realizado. O sistema irá importar os dados que vêem da Câmara para o órgão executor, registrando todas as ocorrências e permitindo cadastrar as emendas parlamentares restantes, cadastrar os Municípios beneficiários, cadastrar os autores de emendas genéricas e de bancadas, avisar da liberação pela Casa Civil das verbas, liberar o empenho da verba e efetuar todo o fluxo de trabalho no ciclo orçamentário-financeiro do órgão. Com o acompanhamento das emendas parlamentares o gestor não irá se preocupar com os saldos restantes a serem enviados para os Municípios beneficiários, nem com o cadastro das emendas uma vez que tais operações são efetuadas de forma totalmente automatizada, garantindo o perfeito equilíbrio no orçamento da instituição. ${ }^{35}$

Resta, contudo, esclarecer que os dados relacionados às emendas parlamentares têm uma divulgação mais acentuada nas páginas eletrônicas do Poder Legislativo, como Orçamento Brasil, da Câmara dos Deputados, e Siga Brasil, do Senado, que se propõem a uma maior transparência, e não propriamente nos portais de transparência dos recursos públicos.

\subsubsection{Complexidade do atendimento aos requisitos}

Outro ponto de relevância apontado pelo relatório concerne à complexidade dos requisitos para o acesso aos recursos governamentais disponibilizados para a realização

34 BRASIL. Congresso Nacional, Comissão Parlamentar Mista de Inquérito "das Ambulâncias", cit., p. 419.

35 PADRÃO IX SISTEMAS ABERTOS S/A. Controle de Emendas Parlamentares. Portal Padrão IX Sistemas Abertos S/A. Disponível em: http://www.pix.com.br/?page_id=175. Acesso em: 21 set. 2015. 
de transferências voluntárias entre os entes da federação, o que representa uma dificuldade especialmente aos pequenos Municípios, que carecem de estrutura adequada para o acompanhamento das iniciativas. Nesse sentido, aponta o relatório:

Para que um ente público ou privado consiga celebrar convênio com a União, é necessário:

- Conhecer os programas de Governo disponíveis.

- Ter acesso às informações sobre o processo de habilitação.

- Preparar a documentação necessária para a formalização do convênio.

- Receber a aprovação do órgão concedente. ${ }^{36}$

A respeito das dificuldades enfrentadas, prossegue o relatório:

A preparação do Plano de Trabalho, com a consequente formalização do convênio, é um processo de grande complexidade e inúmeros detalhes. Em particular, para prefeituras de Municípios de pequeno porte, apresenta-se como barreira quase intransponível, diante da necessidade de se obterem recursos para atender às necessidades da comunidade. Vale dizer que, já no ano de 1996, como se verá mais adiante nesse trabalho, auditoria de natureza operacional realizada pelo TCU detectava tal dificuldade para os convenentes. Isso, num momento em que as exigências para se firmarem convênios eram menores do que hoje. Essa realidade, por si, já cria ambiente propício para a "venda de facilidades" no âmbito da Administração.

Ao longo dos anos, diversos atores que começaram a participar do processo de elaboração de emendas parlamentares e posterior formalização e execução de convênios, tornaram-se profundos conhecedores desses trâmites e exigências, passando a atuar na assessoria de parlamentares exclusivamente nessa área, tornando-se, por sua qualificação, profissionais valorizados.

$\mathrm{Na}$ outra perspectiva, as emendas parlamentares individuais foram tendo seus valores aumentados de exercício a exercício, chegando hoje a $\mathrm{R} \$ 5$ milhões por deputado por ano (no momento de redação desse relatório está sendo votado o aumento dessa verba para R \$ 6 milhões por deputado por ano). Ao longo de diversos Governos, sua aprovação estabeleceu-se como elemento de mediação na relação entre o Poder Executivo e o Poder Legislativo, e são inúmeras as denúncias veiculadas na imprensa, nos últimos anos, de liberação de valores altíssimos a título de emendas parlamentares em datas próximas às votações de matérias do interesse do Poder Executivo, ou em anos eleitorais.

Nesse contexto, proliferaram, portanto, a ocorrência de ilícitos, mediante a participação de atores como o Grupo Planam, que representa a dimensão empresarial de um esquema que conta com servidores do Poder Executivo que facilitam a tramitação dos processos em seus respectivos órgãos, e com os agentes especializados que atuam

36 BRASIL. Congresso Nacional, Comissão Parlamentar Mista de Inquérito "das Ambulâncias", cit., p. 431. 
como assessores parlamentares ou mesmo na qualidade de consultores para elaboração de projetos, e parlamentares. ${ }^{37}$

Assim, não obstante a grande relevância ostentada pelo SICONV, sobressai no contexto analisado a vulnerabilidade de certos Municípios diante do sistema, tendo em vista a necessidade de que tenham iniciativa para pleitear recursos junto aos projetos desenvolvidos na esfera federal. Exige-se, assim, um aparato técnico com treinamento suficiente para interagir com o sistema, o que nem sempre pode representar uma tarefa fácil a alguns deles, principalmente quando detêm estrutura precária de assessoramento e tecnologia para a imersão. Com efeito, na medida em que "O acesso aos recursos se dá por meio de proposta ou projeto formulado pelo próprio interessado, diretamente ao Ministério/Secretaria ou à entidade que disponha de recursos aplicáveis ao objeto pretendido, ou quando se deseja implementar programas federais", 38 torna-se necessária a existência de uma estrutura capaz de participar efetivamente de todas as etapas operacionalizadas via SICONV, desde a captação dos recursos até a efetiva prestação de contas.

As dificuldades apontadas acabam por criar vicissitudes do sistema, na medida em que propiciam o desenvolvimento de todo um aparelhamento paralelo externo, e, às vezes, até mesmo dentro dos entes federados envolvidos. Conforme explicado no Relatório da CPI:

$\mathrm{O}$ quadro de irregularidades verificadas pelo TCU, acima, diz respeito às impropriedades verificadas nos $2^{\circ}$ e $3^{\circ}$ itens acima. Nesse contexto surgem as açōes de grupos como a Planam, que dispóem de informaçôes a respeito da elaboração do orçamento da União, das emendas aprovadas, dos planos de Governo, que contratam serviço especializado para a preparação do processo de habilitação, e, ao final dessa fase inicial, mantêm sua rede de interesses funcionando no interior do órgão concedente, com o objetivo de facilitar a aprovação dos processos, inclusive com o saneamento da proposta, ou até mesmo a sua aprovação à revelia dos requisitos legais mencionados anteriormente.

Além disso, os órgãos concedentes não dispõem de estrutura adequada para fiscalização e controle do atendimento aos requisitos necessários para a aprovação dos convênios, e, em alguns casos, há servidores dessa área também envolvidos com os esquemas articulados. ${ }^{39}$

Vê-se, assim, que a clareza e transparência dos dados que envolvem as transferências voluntárias, especialmente por meio de emendas, constituem instrumentos importantes para inibir determinadas práticas abusivas perpetradas por agentes públicos.

37 BRASIL. Congresso Nacional, Comissão Parlamentar Mista de Inquérito "das Ambulâncias”, cit., p. 426.

38 CIRIBELI, João Paulo; MIQUELITO, Samuel; MASSARDI, Wellington de Oliveira, cit., p. 75.

39 BRASIL. Congresso Nacional, Comissão Parlamentar Mista de Inquérito "das Ambulâncias", cit., p. 431. 


\subsubsection{Divisão do elenco das falhas apuradas em cada uma das fases do convênio}

O relatório da CPI levantou diversos aspectos envolvendo irregularidades e falhas frequentes na fase de formalização dos convênios, verificadas pelo Tribunal de Contas da União. Contudo, para efeitos do presente trabalho, serão apontados apenas os aspectos que tenham pertinência direta às transferências entre os entes federados, deixando de lado as conclusôes relativas às organizaçôes da sociedade civil, salvo aquelas que possam ter algum reflexo no estudo das transferências voluntárias.

\subsubsection{Irregularidades na fase de celebração dos convênios}

No tocante à fase de celebração dos convênios, destacam-se, por sua pertinência com o âmbito das transferências voluntárias, as seguintes irregularidades apontadas pelo relatório:

a) desvio de finalidade na celebração do ajuste:

Aponta o relatório para a existência de:

proposições de caráter muito abrangente, sem especificação detalhada, objetiva, clara e precisa do que se pretendia obter ou realizar. Chega-se a ter dois projetos técnicos e dois planos de trabalho para um só convênio, resultando em extrapolação do objetivo do programa e da finalidade da ação orçamentária, bem como do público-alvo beneficiário previsto na ação. Inobservância de sua forma de implementação.

A consequência da falha apontada seria o "desvio de recursos de programas orçamentários para aplicação em finalidades diversas das aprovadas no Orçamento Geral da União”.

Especificamente no tocante às transferências de recursos entre os entes federados operadas via SICONV, observa-se o estabelecimento de contornos mais nítidos, salientando-se que a instituição do sistema serviu para precisar - ao menos em parte - a dimensão dos projetos, tendo em vista a necessidade de apontar, de forma minuciosa, os objetivos e ações dos programas cadastrados.

Contudo, persiste a amplitude em algumas emendas parlamentares. Conforme informações extraídas da página do Senado Federal, as emendas às despesas podem ser de remanejamento, de apropriação ou de cancelamento, sendo que:

(...) as emendas de remanejamento são as que acrescentam ou incluem dotações e, simultaneamente, como fonte exclusiva de recursos, anulam dotaçóes equivalentes, excetuando as reservas de contingência. Tais emendas só podem ser aprovadas com a anulação das dotações indicadas, observada a compatibilidade das fontes de recursos.

Já as emendas de apropriação são que acrescentam ou incluem dotações e, simultaneamente, como fonte de recursos, anulam valor equivalente proveniente de outras 
dotações e de verbas da chamada Reserva de Recursos. As emendas de cancelamento propõem, exclusivamente, a redução de dotações orçamentárias. ${ }^{40}$

Assim, especialmente na esfera estadual, verifica-se que grande parte das emendas parlamentares cuidam de remanejamento de recursos de uma rubrica orçamentária para outra, em consonância ao disposto no artigo $166, \S 3^{\circ} \mathrm{da} C F$ :

Art. 166. Os projetos de lei relativos ao plano plurianual, às diretrizes orçamentárias, ao orçamento anual e aos créditos adicionais serão apreciados pelas duas Casas do Congresso Nacional, na forma do regimento comum.

(...)

$\$ 3^{\circ}$ As emendas ao projeto de lei do orçamento anual ou aos projetos que o modifiquem somente podem ser aprovadas caso:

I - sejam compatíveis com o plano plurianual e com a lei de diretrizes orçamentárias;

II - indiquem os recursos necessários, admitidos apenas os provenientes de anulação de despesa, excluídas as que incidam sobre:

a) dotaçôes para pessoal e seus encargos;

b) serviço da dívida;

c) transferências tributárias constitucionais para Estados, Municípios e o Distrito Federal; ou

III - sejam relacionadas:

a) com a correção de erros ou omissóes; ou

b) com os dispositivos do texto do projeto de lei.

Assim, ao promoverem o remanejamento, algumas emendas acabam sendo bastante abrangentes, sem contornos precisos, o que permite sua destinação a finalidades diversas daquelas inicialmente concebidas. Seguem, por exemplo, algumas emendas apresentadas ao Projeto de Lei Estadual n. 1.291, de 2014 (proposta orçamentária do Estado de São Paulo para 2015):

EMENDA N. 326, AO PROJETO DE LEI N. 1.291/2014

Remanejamento de recursos orçamentários da Casa Civil para a Secretaria da Saúde, destinados para as Santas Casas.

EMENDA N. 4.457, AO PROJETO DE LEI N. 1.291/2014

Remaneja recursos da Secretaria de Saúde ao Município de Arujá.

40 PONTUAL, Helena Daltro. Emendas ao Orçamento. Portal Senado Notícias. Disponível em: <http://www12.senado.leg.br/noticias/glossario-legislativo/emendas-ao-orcamento.> Acesso em: 26 ago. 2015. 


\section{EMENDA N. 4.475, AO PROJETO DE LEI N. 1.291/2014}

Remaneja recursos da Secretaria de Saúde ao Município de Mogi Guaçu, para custeios hospitalares.

Já outras emendas dispõem de uma maior precisão, apresentando-se de forma mais específica e com finalidade mais delimitada, consoante demonstram os exemplos abaixo:

\section{EMENDA N. 336, AO PROJETO DE LEI N. 1.291/2014}

Remanejamento de recursos orçamentários da Casa Civil para a Secretaria de Esporte, Lazer e Juventude visando a construção de arquibancada no estádio municipal, bem como a reforma do campo de futebol da Vila Bandeirantes, no Município de Ibaté.

EMENDA N. 337, AO PROJETO DE LEI N. 1.291/2014

Remanejamento de recursos orçamentários da Casa Civil para a Secretaria da Saúde visando a aquisição de um aparelho radiológico para o Município de Ibaté.

Em abono às emendas de caráter mais abrangente, argumenta-se que as transferências sem finalidade específica acabam por se constituir em importante instrumento de autonomia do gestor, em detrimento à efetividade do controle finalístico das transferências voluntárias.

b) falhas nas justificativas dos planos de trabalho e objeto impreciso:

O relatório também apontou a questão da deficiência da fundamentação dos planos de trabalho apresentados pelos interessados na formalização de convênios:

A justificativa da proposição constante dos planos de trabalho não relaciona objetivamente a realidade dos fatos abordados aos objetivos das proposições, não comprovam a necessidade de celebração do convênio e nem demonstram em que ponto existe a coincidência de interesses entre a instituição convenente e o ente estatal concedente, em benefício da finalidade pública. ${ }^{41}$

Tal prática traz como consequência a "celebração de convênios sem a adequada análise da situação de carência, da realidade dos fatos e da veracidade da proposição. Investimentos realizados em ações que podem não ser de interesse público". ${ }^{2}$

Da mesma maneira, constatou-se a falta de precisão do objeto conveniado:

Descrição do objeto faltando especificação completa de seus elementos característicos de forma detalhada, objetiva, clara e precisa, de modo a permitir a identificação exata

41 BRASIL. Congresso Nacional, Comissão Parlamentar Mista de Inquérito "das Ambulâncias", cit., p. 428.

42 BRASIL. Congresso Nacional, Comissão Parlamentar Mista de Inquérito "das Ambulâncias", cit., p. 428. 
do que se pretende realizar ou obter [trazendo como consequência a] dificuldade para verificação do desvio de finalidade na aplicação recursos, impossibilidade de acompanhamento posterior da execução e de avaliação objetiva da prestação de contas. ${ }^{43}$

Contudo, com a implantação do SICONV, houve um maior rigor formal quanto às exigências a serem observadas por ocasião da apresentação do plano de trabalho, inclusive a delimitação do objeto, salientando-se que o artigo 25 da Portaria Interministerial n. 507/2011, ao dispor sobre os requisitos a serem observados na apresentação do Plano de Trabalho, engloba, em seus incisos I e II, respectivamente, a justificativa para a celebração do instrumento e a descrição completa do objeto a ser executado. ${ }^{44}$

\subsubsection{Irregularidades na fase de execução dos convênios}

Ao lado das irregularidades no processo de celebração, o documento aponta ainda as irregularidades e falhas mais frequentes na fase de execução dos convênios, aplicáveis também às transferências entre os entes federados, verificadas pelo TCU. São elas:

a) fiscalização da execução do objeto do convênio insatisfatória ou não realizada;

b) incompatibilidade entre as etapas/fases de execução efetiva e aquelas pactuadas no Plano de Trabalho;

c) incompatibilidade entre as especificações ajustadas no Plano de Trabalho e o que foi efetivamente realizado;

d) inexecução ou execução parcial do objeto pactuado;

e) movimentação dos recursos em conta não específica ou banco não autorizado;

f) movimentação irregular da conta específica do convênio;

g) liberação de recursos em desacordo com o cronograma de desembolso, elaborado com base na execução física do objeto;

43 BRASIL. Congresso Nacional, Comissão Parlamentar Mista de Inquérito "das Ambulâncias", cit., p. 428.

44 Dispõe o artigo 25 da Portaria: Art. 25. O Plano de Trabalho, que será avaliado após a efetivação do cadastro do proponente, conterá, no mínimo:

I - justificativa para a celebração do instrumento;

II - descrição completa do objeto a ser executado;

III - descrição das metas a serem atingidas;

IV - definição das etapas ou fases da execução;

$\mathrm{V}$ - cronograma de execução do objeto e cronograma de desembolso; e

VI - plano de aplicação dos recursos a serem desembolsados pelo concedente e da contrapartida financeira do proponente, se for o caso. 
b) liberação de recursos estando a convenente pendente de prestação de contas parcial referente às parcelas anteriores;

i) não aplicação dos recursos no mercado financeiro enquanto não empregados na sua finalidade;

j) rendimentos das aplicações financeiras não aplicados no objeto do convênio ou computados como contrapartida devida pela convenente;

k) indícios de fraude nos pagamentos e documentos comprobatórios;

l) comprovação de despesas com documentos não fiscais ou ilegítimos: "comprovação de despesas mediante simples recibos, emitidos por pessoas jurídicas que estavam obrigadas à emissão de notas fiscais de serviços, e por pessoas físicas sem a competente retenção de ISS e INSS";

m) ocorrência de saques sem comprovação de despesa;

n) saques não compatíveis com a execução do serviço/entrega de materiais;

o) contrapartida financeira não executada conforme regulamentada ou pactuada;

p) indício de comprovação de despesas mediante notas fiscais "frias" ou "geladas";

q) indício de comprovação de despesas mediante notas fiscais "calçadas". ${ }^{4}$

A instituição do SICONV em muito contribuiu para a diminuição, e até mesmo para o afastamento, de algumas das irregularidades apontadas, tornando a fiscalização das transferências e a própria execução dos convênios mais efetivas, permitindo, ainda, um controle maior exercido não apenas pelos órgãos de controle como também pela própria sociedade como um todo.

Nessa medida, a título ilustrativo, observa-se o saneamento de forma genérica das irregularidades apontadas nos itens $a, b, c$ e $d$ pelo SICONV, ao permitir uma fiscalização muito mais efetiva, proporcionando a confrontação entre o plano de trabalho apresentado e sua execução. Já a questão relativa à movimentação dos recursos financeiros, disposta nos itens $e, f, i$ e $j$, foi suprida com a disciplina veiculada pelo artigo $64 \mathrm{da}$ Portaria Interministerial n. 507/2011, ${ }^{46}$ que regulou a obrigatoriedade de depósito dos recursos em conta bancária específica, em cumprimento à previsão já anteriormente veiculada pelo $\$ 4^{\circ}$ do artigo 116 da Lei de Licitações (Lei Federal n. 8.666/93), bem como do artigo $10, \$ \$ 4^{\circ}$ e $5^{\circ}$ do Decreto n. $6.170 / 2007 .{ }^{47} \mathrm{O}$ mesmo também se pode

45 BRASIL. Congresso Nacional, Comissão Parlamentar Mista de Inquérito "das Ambulâncias”, cit., p. 439.

46 Dispõe o artigo 64: Os recursos deverão ser mantidos na conta bancária específica do convênio e somente poderão ser utilizados para pagamento de despesas constantes do Plano de Trabalho ou para aplicação no mercado financeiro, nas hipóteses previstas em lei ou nesta Portaria. (...)

47 Vejam-se os artigos $116, \$ \$ 4^{\circ}$ e $5^{\circ}$, da Lei n. 8.666/93 e $10, \$ \$ 4^{\circ}$ e $5^{\circ}$ do Decreto Federal n. 6.207/2007: 
apontar no tocante às irregularidades apontadas nos itens $g$ e $h$, em relação ao levantamento dos recursos, somente admitidos diante da regularidade da execução e da prestação de contas de recursos já recebida.

Em suma, todos os atos relacionados ao pagamento deverão ser inseridos no sistema, proporcionando um controle efetivo de forma a abarcar as irregularidades apontadas.

\subsection{SUGESTÃO DA CPI QUANTO AO TÉRMINO DAS TRANSFERÊNCIAS VOLUNTÁRIAS}

Ao término dos seus trabalhos, a chamada CPI das Ambulâncias sugeriu o término das transferências voluntárias. Em razão da grande quantidade de ilícitos apurados pela Comissão, os parlamentares entenderam que essa medida seria hábil para contornar o problema, haja vista que a instituição de novos critérios para a sua realização iria apenas fomentar a prática das irregularidades verificadas nos processos analisados. Isso não significaria, contudo, a apropriação dos valores pela União, nem tampouco a privação dos entes federados do recebimento dos recursos, que seriam objeto de remanejamento orçamentário. Nesse sentido:

\section{Art. $116(\ldots)$}

$\$ 4^{\circ}$ Os saldos de convênio, enquanto não utilizados, serão obrigatoriamente aplicados em cadernetas de poupança de instituição financeira oficial se a previsão de seu uso for igual ou superior a um mês, ou em fundo de aplicação financeira de curto prazo ou operação de mercado aberto lastreada em títulos da dívida pública, quando a utilização dos mesmos verificar-se em prazos menores que um mês.

$\$ 5^{\circ}$ As receitas financeiras auferidas na forma do parágrafo anterior serão obrigatoriamente computadas a crédito do convênio e aplicadas, exclusivamente, no objeto de sua finalidade, devendo constar de demonstrativo específico que integrará as prestações de contas do ajuste. Decreto Federal n. 6.207/2007:

Art. 10. As transferências financeiras para órgãos públicos e entidades públicas e privadas, decorrentes da celebração de convênios e contratos de repasse, serão feitas exclusivamente por intermédio de instituição financeira oficial, federal ou estadual, que poderá atuar como mandatária da União para execução e fiscalização.

(...)

$\$ 4^{\circ}$ Os recursos de convênio, enquanto não utilizados, serão obrigatoriamente aplicados em cadernetas de poupança de instituição financeira pública federal se a previsão de seu uso for igual ou superior a um mês, ou em fundo de aplicação financeira de curto prazo ou operação de mercado aberto lastreada em títulos da dívida pública, quando a utilização desses recursos verificar-se em prazos menores que um mês.

$\$ 5^{\circ}$ As receitas financeiras auferidas na forma do $\$ 4^{\circ}$ serão obrigatoriamente computadas a crédito do convênio e aplicadas, exclusivamente, no objeto de sua finalidade, observado o parágrafo único do art. 12 . 
Não é de se esperar que, uma vez extintas essas transferências, a União venha a apropriar-se desses valores, bem como não é de se supor haver qualquer interesse por parte de estados e Municípios de não mais receberem esses recursos. Assim, como conseqüência lógica da extinção da modalidade de transferência utilizada, e tendo em vista sua motivação, tais recursos deverão ser repassados aos mesmos destinatários, devendo-se, para tanto, definir a forma de sua efetivação, partindo-se do princípio de que os recursos deverão ser distribuídos de maneira uniforme, à semelhança das repartições efetuadas para as transferências constitucionais, quais sejam, o Fundo de Participação dos Estados e o Fundo de Participação dos Municípios. ${ }^{48}$

O relatório aponta, assim, os benefícios de eventual supressão das transferências voluntárias, com base nas apontadas vicissitudes do sistema:

- Distribuição equânime dos recursos, alcançando a totalidade dos Municípios e estados, sem predominância do interesse político partidário;

- Restrição à possibilidade de utilização do poder de liberação de verbas por parte do Poder Executivo em sua relação com o Poder Legislativo;

- Restrição ao estabelecimento de relações indevidas entre membros do Poder Legislativo e a iniciativa privada;

- Restrição à criação de relações políticas marcadas por favorecimento e fraudes entre membros do Poder Legislativo e Prefeitos municipais;

- Diminuição das atribuições dos Ministérios;

- Restrição ao surgimento de esquemas articulados dentro dos Ministérios cujo objetivo seja o desvio de recursos públicos relativos às transferências voluntárias;

- Concentração do esforço de controle e prestação de contas apenas nas instâncias estadual e municipal com conseqüente diminuição das atribuições dos órgãos de controle federais.

Quanto ao último item acima descrito, é necessário fazer alguns esclarecimentos. Ainda que a temática desta CPMI seja de grande repercussão quanto a seus efeitos para as instituições do Estado e pelas conseqüências que gera na mídia e em todo o universo da nação brasileira, o montante dos recursos envolvidos nessas operações é percentualmente pequeno em relação às grandes rubricas do orçamento da União.

O esforço despendido para a realização de fiscalizações sobre a execução dos convênios e ajustes similares, que muitas vezes referem-se a valores que não ultrapassam $R$ \$ 100 mil, iguala-se ou é próximo ao esforço realizado para a fiscalização de valores que alcançam R \$ 100 milhões. ${ }^{49}$

48 BRASIL. Congresso Nacional, Comissão Parlamentar Mista de Inquérito "das Ambulâncias", cit., p. 654.

49 BRASIL. Congresso Nacional, Comissão Parlamentar Mista de Inquérito "das Ambulâncias", cit., p. 655. 
Entendemos, porém, que a supressão das transferências voluntárias não seria a medida mais adequada para saneamento dessas irregularidades, porque, além de efetivamente constituir apenas o pano de fundo para uma questão muito mais complexa envolvendo as vicissitudes do pacto federativo, implicariam na drástica redução de um importante instrumento de autonomia dos entes federados, engessando ainda mais a já limitada esfera de discricionariedade do gestor na aplicação dos recursos públicos.

\subsection{PROPOSTAS EM FACE DAS DISTORÇÕES APRESENTADAS}

De tudo o que foi exposto, verifica-se que a constatação de irregularidades, desvios e mau emprego dos recursos tende a macular a sistemática das transferências voluntárias de recursos que, por seu turno, são extremamente importantes a diversos entes federados, visto que muitas vezes representam a única forma de concretização de novos investimentos. Mas não é só. Em alguns casos, como já salientado, os recursos advindos das transferências voluntárias são essenciais à própria realização de despesas de custeio, desde que não resvalem no pagamento de despesas com pessoal, hipótese em que a vedação é expressa.

A constatação veiculada ressalta importante aspecto federativo que merece ser melhor examinado, particularmente no tocante à análise da viabilidade de manutenção de um ente federado que apresente alto grau de dependência de outras instâncias federativas para a consecução de suas próprias despesas de custeio.

Nesse aspecto, enquanto medida inserida na esfera do federalismo, a título de sugestão, sobressai a conveniência da realização de estudos voltados ao acompanhamento dos Municípios nessa situação, inclusive por meio do "assessoramento" do Estado-membro a que pertença, objetivando o auxílio ao saneamento de suas contas. Após determinado período, constatada a insuficiência financeira dos Municípios para a manutenção de sua própria autonomia, poderiam ser abertas oportunidades de composição federativa dos mencionados entes, especialmente por meio dos instrumentos de fusão ou incorporação, tendo em vista a previsão contida no artigo 18 da Constituição Federal..$^{0}$

50 Dispōem o artigo 18 da Constituição e seus parágrafos: Art. 18. A organização político-administrativa da República Federativa do Brasil compreende a União, os Estados, o Distrito Federal e os Municípios, todos autônomos, nos termos desta Constituição.

$\$ 1^{\circ}$ Brasília é a Capital Federal.

$\$ 2^{\circ}$ Os Territórios Federais integram a União, e sua criação, transformação em Estado ou reintegração ao Estado de origem serão reguladas em lei complementar.

$\$ 3^{\circ}$ Os Estados podem incorporar-se entre si, subdividir-se ou desmembrar-se para se anexarem a outros, ou formarem novos Estados ou Territórios Federais, mediante aprovação da 
Outra sugestão interessante, extraída do relatório da CPI, refere-se à criação de critérios mais claros acerca da liberação ou não de emendas. Nessa medida, restou consignado no documento, enquanto sugestão de José Carlos Aleluia:

Mais importante do que a criação do novo sistema mencionado seria a decisão clara, explícita e transparente quanto à liberação ou não das emendas, o que impediria de pronto a venda de facilidades. Seria o caso de se definir quais emendas não seriam liberadas, tornando pública a decisão. O fato é que quem não se submete ao rito corrupto, ou pelo menos viciado de dar preferência para determinada empresa, não consegue liberar suas emendas. ${ }^{51}$

Com efeito, a criação de critérios objetivos acerca da liberação ou não de emendas tende a propiciar a diminuição das barganhas políticas estabelecidas entre os atores do orçamento, que resultam no atendimento a demandas nem sempre prioritárias à sociedade.

Além da padronização dos critérios de liberação de emendas, o que de certa forma acabou sendo implementado com a instituição do orçamento impositivo para as emendas parlamentares, também se mostra adequado o condicionamento dessas operações a critérios preestabelecidos e objetivos, como, por exemplo, o IDH do ente federado, ${ }^{52} \mathrm{o}$ histórico de recebimento de transferências voluntárias, o nível de eficiência no emprego dos recursos auferidos, entre outros.

\subsection{FISCALIZAÇÃO E CONTROLE DAS TRANSFERÊNCIAS}

Sem prejuízo da publicação de todos os atos relativos às transferências no SICONV, inclusive a prestação de contas dos recursos recebidos, de forma a permitir

população diretamente interessada, através de plebiscito, e do Congresso Nacional, por lei complementar.

$\$ 4^{\circ}$ A criação, a incorporação, a fusão e o desmembramento de Municípios, far-se-ão por lei estadual, dentro do período determinado por Lei Complementar Federal, e dependerão de consulta prévia, mediante plebiscito, às populaçóes dos Municípios envolvidos, após divulgação dos Estudos de Viabilidade Municipal, apresentados e publicados na forma da lei. (Grifo nosso)

51 BRASIL. Congresso Nacional, Comissão Parlamentar Mista de Inquérito “das Ambulâncias”, cit., p. 650.

52 Nesse contexto, o parlamentar Raul Jungmann apresentou sugestão interessante referente ao uso dos indicadores de desenvolvimento social: "Pontualmente, poderiam ser definidos critérios de elegibilidade para as transferências voluntárias, que se orientassem por matrizes de aplicação de recursos que levassem em conta, por exemplo, o IDH do Municípios, entre outros indicadores objetivos" (BRASIL. Congresso Nacional, Comissão Parlamentar Mista de Inquérito "das Ambulâncias", cit., p. 651). 
o controle e o acesso por qualquer interessado, a fiscalização das transferências voluntárias efetuadas na esfera federal insere-se no espectro de competências do Tribunal de Contas da União (TCU), conforme o disposto nos artigos $5^{\circ}$, inciso VII, e 41, inciso IV, da Lei Orgânica do Tribunal de Contas da União (Lei Federal n. 8.443, de 16 de julho de 1992), nos seguintes termos:

Art. $5^{\circ}$. A jurisdição do Tribunal abrange:

(...)

VII - os responsáveis pela aplicação de quaisquer recursos repassados pela União, mediante convênio, acordo, ajuste ou outros instrumentos congêneres, a Estado, ao Distrito Federal ou a Município;

(...)

Art. 41. Para assegurar a eficácia do controle e para instruir o julgamento das contas, o Tribunal efetuará a fiscalização dos atos de que resulte receita ou despesa, praticados pelos responsáveis sujeitos à sua jurisdição, competindo-lhe, para tanto, em especial:

(...)

IV - fiscalizar, na forma estabelecida no Regimento Interno, a aplicação de quaisquer recursos repassados pela União mediante convênio, acordo, ajuste ou outros instrumentos congêneres, a Estado, ao Distrito Federal ou a Município.

Assim, todas as fases do convênio, desde sua celebração até a prestação de contas, constituem objeto de controle do TCU, sem prejuízo, ainda, do controle exercido pelos próprios órgãos integrantes do Poder Executivo, como a Controladoria-Geral da União (CGU), que o exerce por meio da Secretaria Federal de Controle Interno (SFC). No entanto, é cediço o reconhecimento da falta de recursos e de estrutura hábil ao efetivo acompanhamento e à fiscalização da execução dos convênios celebrados. Nesse sentido, restou consignado no Acórdão 788/2006, do Tribunal de Contas da União, a verificação rotineira de falhas apontadas em seus julgados:

A recorrência dessas falhas na transferência de recursos federais por convênios e contratos de repasse aponta para deficiências estruturais dos órgãos repassadores, controles inexistentes ou ineficientes e falta de servidores habilitados a analisar e fiscalizar a descentralização de recursos em número compatível com o volume de instrumentos celebrados. Essa situação tem-se mantido ao longo do tempo, não obstante as decisões desta Corte e as recomendações da CGU.53

O relatório da CPI das Ambulâncias apontou para um estudo realizado pela CGU acerca da eficácia da fiscalização feita pelos órgãos de controle interno, corroborando a conclusão no sentido de ausência de recursos para a realização dessa tarefa. Nesse sentido, concluiu o documento:

53 BRASIL. Tribunal de Contas da União. Acórdão 788/2006-Plenário. Relator: Ministro Augusto Cherman. Brasília, 24 mai. 2006. Diário Oficial da União, 26 maio 2006. 
A CGU realizou trabalho no qual intentava conhecer a realidade dos mecanismos de controle dos órgãos repassadores de recursos federais por meio de transferências voluntárias. $\mathrm{O}$ resultado foi a constatação de que esses órgãos estão completamente desestruturados para a realização das ações de controle relativamente ao resultado alcançado mediante a aplicação desses recursos.

A Nota Técnica n. 600/2002 GSGAB/SFC/CGU-PR 'evidencia a situação dos controles internos dos órgãos/entidades que mais operacionalizam transferências de recursos públicos, em especial à Prestação de Contas de convênios e contratos de repasse (...)'. Recentemente, a CGU fez a atualização dos dados, que podem ser visualizados nos demonstrativos abaixo. $\mathrm{O}$ trabalho registrou a evolução da situação das prestaçôes de contas no período ao longo dos exercícios de 2002 a 2006, fazendo levantamento comparativo dos convênios que encontram-se nas situaçôes "a comprovar" e "a aprovar" nos registros efetuados no SIAFI. ${ }^{54}$

Em continuidade acerca do estudo, revela o relatório:

O que se vê portanto, nesse levantamento, é a escalada do problema. O fato é que os órgãos repassadores não dispõem de estrutura adequada para o controle e a fiscalização dos convênios. Assim, chega-se a números assombrosos como esses, revelando que em relação a 23.847 convênios não foi feita a aprovação das prestações de contas, em valor que alcança $\mathrm{R} \$ 7$ bilhões. ${ }^{55-56}$

Quanto a esse aspecto, a Portaria Interministerial n. 507/2011 exige que o concedente dê efetividade às atividades de acompanhamento do objeto, comprovando a existência de estrutura que permita a sua realização e a fiscalização das obras:

Art. 66. O concedente deverá prover as condições necessárias à realização das atividades de acompanhamento do objeto pactuado, conforme o Plano de Trabalho e a metodologia estabelecida no instrumento, programando visitas ao local da execução com tal finalidade que, caso não ocorram, deverão ser devidamente justificadas.

Parágrafo único. No caso de realização de obras por convênio, o concedente deverá comprovar que dispóe de estrutura que permita acompanhar e fiscalizar a execução do objeto, de forma a garantir a regularidade dos atos praticados e a plena execução do objeto, nos termos desta Portaria, em especial o cumprimento dos prazos de análise da respectiva prestação de contas.

Com base em estudo elaborado pela Controladoria-Geral da União, o relatório da CPI fez um apanhado das falhas detectadas:

54 BRASIL. Congresso Nacional, Comissão Parlamentar Mista de Inquérito "das Ambulâncias", cit., p. 457.

55 BRASIL. Congresso Nacional, Comissão Parlamentar Mista de Inquérito "das Ambulâncias", cit., p. 459.

56 A conclusão diz respeito a dados de 2006. 
c) A Coordenação Geral de Normas e Orientaçōes para o Sistema de Controle Interno da CGU preparou relatório no qual evidenciou os problemas detectados nas transferências voluntárias.

Para efeitos didáticos, fez a divisão da operação em três etapas:

Etapa 1: Análise técnica da proposta apresentada pelo proponente, identificando se há viabilidade técnica, econômica e social que fundamente o repasse.

Etapa 2: Execução do objeto, pelo proponente, e fiscalização da execução por parte do concedente.

Etapa 3: Apresentação da Prestação de Contas pelo convenente e sua posterior análise pelo concedente.

Problemas detectados na Etapa 1:

- Falta de especificações técnicas pré-definidas para análise das propostas;

- Falta de parâmetros de custos pré-estabelecidos;

- Corpo funcional insuficiente em quantidade e qualidade para a execução de uma análise acurada das propostas;

- Propostas apresentadas no encerramento do exercício (pressão para aprovação com vistas à liberação dos recursos ou inscrição em restos a pagar);

- Liberação dos recursos sem a aprovação prévia das propostas.

Problemas detectados na Etapa 2:

- Ausência de fiscalização nos convênios;

- Fiscalizaçôes tecnicamente deficientes;

- Contratação da CEF para execução das fiscalizações, exclusivamente.

Problemas detectados na Etapa 3:

- Análises superficiais das Prestações de Contas, haja vista que as propostas não foram adequadamente formuladas e não houve fiscalização;

- Prestações de Contas aprovadas pela CEF nos Contratos de Repasse.

Relativamente a estas questões, serão apresentadas propostas no item próprio, mais adiante. ${ }^{57}$

Ao final, concluiu que o problema não se refere à falta de normatização, mas sim ao seu efetivo cumprimento:

Vêem-se, aqui, diversas determinações feitas pelo TCU, com vistas à implantação de sistemas de controle da execução de convênios, bem como em relação a demais

57 BRASIL. Congresso Nacional, Comissão Parlamentar Mista de Inquérito "das Ambulâncias", cit., p. 463. 
informações relativas à matéria. Além disso, também foram feitas recomendações à STN que serão transcritas ao final.

Ressalta-se, mais uma vez, a enorme quantidade de determinações feitas aos órgãos com o objetivo único de impor-lhes a observação dos procedimentos legais. O que se afigura com clareza, é que já existem normatização suficiente para direcionar a adequada utilização dos recursos públicos. O que impede que isso aconteça, portanto, não é a deficiência de normativas, é, apenas a sua inobservância. Portanto, desde já não se vislumbra que a implementação de mais uma série de procedimentos e exigências venha a surtir efeito. Pelo contrário, não é errado afirmar que há grande possibilidade de que serão apenas mais dispositivos a serem ignorados. ${ }^{58}$

A par das ponderações extraídas do relatório, a instituição do SICONV veio atender a uma série de expectativas em relação ao controle passo-a-passo de todas as fases de execução de convênios, mostrando-se um instrumento de extrema relevância para o acompanhamento dos ajustes celebrados pelos entes da administração pública que envolvam a transferência de recursos. Não se trata de uma mera norma a ser observada pelos entes federados e convenentes, mas sim de um sistema que se pretende ser amplamente acessível a todos os interessados. Em suma, ele deve funcionar como um espelho dos documentos, refletindo todas as etapas da operação, desde a apresentação da proposta até a aprovação das contas.

Outro ponto lembrado diz respeito ao custo da fiscalização, conforme extraído do relatório da CPI:

Segundo a avaliação do ministro, um dos problemas iniciais para a implementação de toda essa nova sistemática é o evidente aumento dos gastos com o funcionamento e controle de todo o sistema.

A respeito disso, inclusive, foi tratado tema interessante, inicialmente pelo ministro Paulo Bernardo, relativamente ao custo da fiscalização de convênios. Segundo ele, tal ação alcança pelo menos R \$ 40 mil. Ainda segundo o ministro, o Tribunal de Contas da União estimou este custo em R \$ 23 mil. Portanto, ao firmar um convênio de, por exemplo, $\mathrm{R} \$ 15$ mil, seria mais caro fazer o trabalho de acompanhamento, verificação, fiscalização, do que o valor do convênio, o que torna praticamente inviável o controle, ou a contratação. ${ }^{59}$

Desse modo, apesar da ausência de dados estatísticos sobre os custos após a implantação do SICONV, soa até mesmo intuitivo presumir a sensível diminuição não apenas dos custos operacionais, mas também dos custos financeiros da fiscalização,

58 BRASIL. Congresso Nacional, Comissão Parlamentar Mista de Inquérito "das Ambulâncias", cit., p. 596.

59 BRASIL. Congresso Nacional, Comissão Parlamentar Mista de Inquérito "das Ambulâncias", cit., p. 635. 
em razão da ampliação do acesso aos documentos e dados pertinentes, disponibilizados na mesma base de busca. A recomendação para a instituição do sistema foi expressamente prevista no Acórdão TCU 2066/2006-Plenário, especialmente por meio de seu item 9.1:

ACORDAM os Ministros do Tribunal de Contas da União, reunidos em sessão Plenária, ante as razões expostas pelo Relator, em:

9.1. determinar ao Ministério do Planejamento, Orçamento e Gestão que, para possibilitar a transparência que deve ser dada às açōes públicas, como forma de viabilizar o controle social e a bem do princípio da publicidade insculpido no art. 37 da Constituição Federal de 1988 c/c o art. 50, inciso XXXIII, da mesma Carta Magna, no prazo de 180 (cento e oitenta dias), apresente a este Tribunal estudo técnico para implementação de sistema de informática em plataforma web que permita o acompanhamento on-line de todos os convênios e outros instrumentos jurídicos utilizados para transferir recursos federais a outros órgãos/entidades, entes federados e entidades do setor privado, que possa ser acessado por qualquer cidadão via rede mundial de computadores, contendo informaçóes relativas aos instrumentos celebrados, especialmente os dados da entidade convenente, o parlamentar e a emenda orçamentária que alocaram os recursos, se houver, o objeto pactuado, o plano de trabalho detalhado, inclusive custos previstos em nível de item/etapa/fase, as licitaçóes realizadas com dados e lances de todos os licitantes, o status do cronograma de execução física com indicação dos bens adquiridos, serviços ou obras executados, o nome, CPF e dados de localização dos beneficiários diretos, quando houver, os recursos transferidos e a transferir, a execuçáo financeira com as despesas executadas discriminadas analiticamente por fornecedor $\mathrm{e}$ formulário destinado à coleta de denúncias; $(. . .)^{60}$

Nessa medida, sem dúvida a instituição do SICONV representa um passo significativo não apenas na amplitude de acesso aos recursos disponibilizados pelos programas governamentais, mas também como instrumento de ampla fiscalização e de controle dos atos inseridos no sistema.

\subsection{AS TRANSFERÊNCIAS VOLUNTÁRIAS ENQUANTO INSTRUMENTO DE NEGOCIAÇÃO POLÍTICA E AS CONDICIONANTES DE SUA REALIZAÇÃO}

Em razão da discricionariedade que as caracteriza e as diferencia das transferências constitucionais e legais, cujo caráter é obrigatório, as transferências voluntárias destacam-se enquanto mecanismo de negociação política tanto no plano

60 BRASIL. Tribunal de Contas da União. Acórdão 2066/2006-Plenário. Relator: Ministro Marcos Bemquerer. Brasília, 8 nov. 2006. Diário Oficial da União, 13 nov. 2006. Grifo nosso. 
horizontal, no tocante às relações estabelecidas entre os Poderes, como também no plano vertical, entre as diferentes esferas federativas.

No plano horizontal, constituem as transferências voluntárias mecanismo utilizado pelo Chefe do Poder Executivo para a constituição de uma base de coalizão de governo, especialmente no âmbito do Poder Legislativo, como forma de obter sustentação parlamentar. Historicamente, essa movimentação tem nas negociaçôes para liberações de emendas parlamentares o seu principal instrumento. A esse propósito, é importante ressaltar as substanciais alterações sofridas pela sistemática das emendas parlamentares, introduzidas pela Emenda Constitucional n. 86, de 2015, que afastou a discricionariedade na sua execução, tornando-as de cumprimento obrigatório.

Ainda no campo horizontal, a importância das transferências se destaca na nomeação para a ocupação de cargos na esfera administrativa, sendo a disputa dos cargos proporcional ao volume de recursos disponibilizados por meio de repasses. Nesse sentido, aponta Márcia Miranda Soares:

Nas negociações horizontais, a formação de uma coalizão de governo, composta por partidos que detêm a maioria dos deputados e senadores no Congresso Nacional, passa pela distribuição de cargos em órgãos e entidades do Poder Executivo, e estes serão tanto mais disputados quanto maior for o volume de recursos que dispuserem e, tanto melhor, se forem recursos discricionários, o que aumenta o poder dos ocupantes de privilegiar destinatários e políticas. ${ }^{61}$

De outra sorte, ressalta-se a importância da utilização das transferências voluntárias no plano vertical de negociações, isto é, nas relações que se estabelecem com os entes federados. Nesse sentido, a autora aponta que as relações são afetadas por três condicionantes: de natureza político-partidária, de natureza redistributiva e de natureza técnica. Em suas palavras:

O condicionante político-partidário envolveria a busca da União no fortalecimento de suas bases eleitorais e partidárias, privilegiando no recebimento de TVU os entes que deram maior apoio eleitoral ao presidente em exercício, ou beneficiar os governadores e prefeitos dos partidos do presidente ou de sua base aliada. A condicionante redistributiva implica em privilegiar, em uma perspectiva similar às transferências constitucionais e legais, estados ou Municípios mais pobres, com menor capacidade de gasto público. Por fim, podemos supor que as exigências para celebrar um convênio requerem uma estrutura de captação de recursos que envolve apresentação de projetos, negociações técnicas e gestão de convênios, o que pode favorecer os mais capacitados tecnicamente, e os mais ricos podem ser mais eficientes neste quesito. ${ }^{62}$

61 SOARES, Márcia Miranda, cit., p. 4.

62 SOARES, Márcia Miranda, cit., p. 4-5. Grifo nosso. 


\subsubsection{Condicionantes de natureza político-partidária}

Inicialmente, no tocante à condicionante político-partidária, a mais relevante das que incidem sobre as transferências voluntárias, a influência se opera basicamente durante o processo de elaboração e execução orçamentárias. O Poder Executivo, por ocasião da elaboração da proposta orçamentária, elege algumas políticas a serem contempladas com o repasse de recursos orçamentários. Nesse momento, os diversos atores políticos buscam exercer seu poder para a inclusão de demandas de seu interesse no projeto de lei orçamentária a ser encaminhado ao Poder Legislativo. Posteriormente, dando continuidade ao processo político, novas demandas são eleitas por meio das emendas parlamentares, onde a atuação dos atores políticos também se faz presente.

Mesmo depois de superada a fase de elaboração e aprovação da lei orçamentária, momento a partir do qual as previsões assumem caráter autorizativo, as negociações continuam a produzir seus efeitos, e os atores agem visando a efetivar as previsões orçamentárias que atendam às suas demandas. Outro campo passível de negociações de caráter político reside na especificação das despesas com transferências voluntárias que, muito embora previstas, não apresentam destinação específica na lei. Nesse aspecto, surge a possibilidade da influência de fatores políticos, como, por exemplo, o favorecimento de prefeitos do mesmo partido do governo federal ou estadual ou de sua base aliada, por iniciativa não apenas do Chefe do Executivo, como também dos titulares dos ministérios ou secretarias de governo estaduais.

\subsubsection{Condicionantes de natureza social-redistributiva}

Por seu turno, a condicionante social-redistributiva busca atender à finalidade última das transferências intergovernamentais, consistente na equalização fiscal entre os entes federados, isto é, no funcionamento enquanto mecanismo de compensação dos diferentes potenciais arrecadatórios. Em outras palavras, a condicionante equalizadora visa a conferir que, por meio das transferências voluntárias, os entes mais pobres tenham uma compensação pelo volume inferior de arrecadação registrado, em comparação aos demais entes federados de igual natureza.

Essa condição social-redistributiva foi expressamente considerada por ocasião da definição dos percentuais relativos às contrapartidas financeiras dos Municípios nos convênios e contratos de repasses celebrados para o recebimento de transferências voluntárias. Conforme aponta Márcia Miranda Soares, “(...) a contrapartida diferenciada é apenas um incentivo para que os Municípios menos populosos e situados nas regiōes mais pobres recebam TVU, continuando o governo federal com discricionariedade para definir seu destino". ${ }^{63}$

63 SOARES, Márcia Miranda, cit., p. 21. 


\subsubsection{Condicionantes técnicas}

Por fim, ressaltam-se as condicionantes técnicas, concernentes à potencialidade de capacidade técnica dos entes locais para o atendimento das exigências a serem cumpridas para o recebimento dos repasses voluntários de recursos.

A imposição de uma série de requisitos para o recebimento de transferências voluntárias, especialmente os enumerados pelo Decreto n. 6.170/2007 e pela Portaria Interministerial n. 507/2011, além das regras e exigências próprias de ministérios e entidades, revelam uma grande complexidade. Por via reflexa, essa sistemática acaba afastando $\mathrm{Mu}-$ nicípios menos estruturados do processo de captação dos mencionados recursos, tendo em vista a necessidade de combinação de recursos financeiros, humanos e técnicos para a consecução das obrigações decorrentes do recebimento de transferências voluntárias.

\subsection{LEVANTAMENTOS E CONCLUSÕES ALCANÇADAS QUANTO AO ALCANCE DAS CONDICIONANTES}

Não constitui objetivo do presente trabalho o aprofundamento da abordagem das condicionantes político-partidárias, socioeconômicas ou técnicas que possam vir a influenciar as transferências voluntárias, mas não há como passar ao largo de tais aspectos em um estudo que se propõe a abordar o instituto. Por essa razão, buscar-se-á apenas conferir um breve panorama com base em estudos e levantamentos já efetuados, sem, no entanto, a pretensão de se realizar uma análise crítica acerca dos resultados alcançados.

Diversos estudos apontam para a influência dos aspectos político-partidários sobre o volume de transferências voluntárias destinadas aos entes da federação. João Paulo Ciribelli, Samuel Miquelito e Wellington de Oliveira Massardi buscaram demonstrar a efetiva influência dos partidos políticos no processo de alocação dos recursos. Eles analisaram o montante de transferências federais e estaduais para os Municípios do Estado de Minas Gerais administrados pelo Partido dos Trabalhadores (PT) e pelo Partido da Social Democracia Brasileira (PSDB), no período de 2009 a 2012, a fim de verificar se os Municípios administrados pelo PT recebiam mais verbas do governo federal, administrado pelo mesmo partido. Buscou-se também a correlação em nível estadual, administrado pelo PSDB, com relação aos Municípios administrados pelo mesmo partido. Os resultados alcançados corroboraram a tese da efetiva influência político-partidária:

(...) os Municípios cujo prefeito pertencia ao PT obtiveram maiores valores per capita de transferências voluntárias de origem da União (...)

$\mathrm{O}$ mesmo ocorre em relação às transferências voluntárias de origem do governo estadual. Os Municípios do PSDB possuíam maiores receitas provenientes das transferências estaduais do que os Municípios do PT. (... $)^{64}$

${ }^{64}$ CIRIBELI, João Paulo; MIQUELITO, Samuel; MASSARDI, Wellington de Oliveira, cit., p. 78. 
Em seguida, aduzem:

Os resultados obtidos corroboram com o fato de que parlamentares e deputados usam do direito das emendas parlamentares como fonte de conseguir apoio político e usam das transferências voluntárias em benefício comum de seu partido ou coligação. Dessa maneira, o sistema político se entrelaça de forma a proteger direta ou indiretamente os que detêm o poder, dificultando o entrante de novos partidos de oposição. ${ }^{65}$

Citando outros estudiosos do assunto, concluem os autores:

As transferências voluntárias se caracterizam por beneficiar os Municípios com obras para o bem comum da população, acelerando o crescimento e melhorando a qualidade de vida. Pelo seu caráter voluntário, governantes as usam como fonte política de agregação, tal como assinalam Ferreira e Bugarin (2007, p. 271): “(..) as transferências voluntárias intergovernamentais no Brasil são significantemente influenciadas por motivações político-partidárias."

Torres (2004, p. 63) complementa ao afirmar que as transferências voluntárias são usadas para manter, melhorar e controlar a base de sustentação política no congresso, o executivo as utiliza de forma a garantir apoio político dentro do sistema presidencialismo de coalizão. ${ }^{66}$

O trabalho ainda apresentou o percentual de liberação de recursos de transferências voluntárias, com base em dados fornecidos pelas bancadas partidárias da Câmara dos Deputados, demonstrando que os partidos da base aliada, mais especificamente PT, PTB e PMDB, obtiveram, no período de janeiro a agosto de 2013, um volume percentual de emendas parlamentares muito superior aos partidos da oposição (PSDB e DEM), conforme demonstra a Tabela 6.15:

\section{Tabela 6.15 Percentual de emendas parlamentares liberadas, em Minas Gerais, entre janeiro e agosto de 2013, por partido político}

\begin{tabular}{|c|c|}
\hline PARTIDO & PERCENTUAL DE EMENDAS PARLAMENTARES LIBERADAS \\
\hline PTB & $29,61 \%$ \\
\hline PT & $28,33 \%$ \\
\hline PMDB & $26,21 \%$ \\
\hline DEM & $0,20 \%$ \\
\hline PSDB & $0,03 \%$ \\
\hline
\end{tabular}

Fonte: elaboração própria a partir de CIRIBELI, João Paulo; MIQUELITO, Samuel; MASSARDI, Wellington de Oliveira, cit., p. 78.

65 CIRIBELI, João Paulo; MIQUELITO, Samuel; MASSARDI, Wellington de Oliveira, cit., p. 80. 66 CIRIBELI, João Paulo; MIQUELITO, Samuel; MASSARDI, Wellington de Oliveira, cit., p. 75. 
No mesmo sentido, Márcia Miranda Soares realizou uma análise sobre as transferências voluntárias realizadas entre os anos de 1995 a 2010, tendo por objetivo verificar a influência exercida pelas três variáveis anteriormente mencionadas, as quais denominou de "dimensóes explicativas: a político-partidária, a redistributiva e a da eficiência" ${ }^{67} \mathrm{O}$ levantamento apontou que "receberam mais recursos de TVU os Municípios em que os prefeitos eram do mesmo partido que o presidente, que proporcionaram maior votação ao presidente em sua eleição ou que tem partidários à frente de ministérios que concentram TVU" (dimensão político-partidária) ${ }^{68}$ Assim, Municípios governados por prefeitos do mesmo partido do presidente receberam um volume maior de recursos, fenômeno verificado tanto no período sob governo do PSDB como do PT.

Ao contrário, como regra, não restaram demonstrados: a) a captação de volume maior de recursos pelos Municípios onde o Presidente obteve melhores resultados eleitorais; b) o recebimento de volume maior de recursos em ano eleitoral; c) o recebimento de volume maior de recursos pelos Municípios que têm o partido do prefeito à frente do Ministério responsável pela transferência.

De qualquer forma, independentemente da influência da questão partidária ou não, tendo em vista a ausência de uma padronização comportamental das transferências voluntárias com base na condicionante político-partidária, esses repasses são inegavelmente uma forma de se implementarem benefícios à população dos Municípios envolvidos. O que se contesta é apenas o critério de escolha de prioridades, porque muitas vezes não é considerada a efetiva necessidade das populações envolvidas, mas sim o interesse político-partidário que a permeia. Os efetivos propósitos das transferências voluntárias, de redução das desigualdades sociais e melhoria dos índices de qualidade de vida, são distorcidos em prol dos interesses partidários.

Assim, ressalta-se a necessidade do desenvolvimento de mecanismos que inibam a escolha por critérios exclusivamente políticos. Isso pode ser obtido por meio da vinculação a necessidades efetivas da população, que poderá se efetuar pelo estabelecimento de critérios de natureza objetiva, levando-se em conta variáveis como população, Produto Interno Bruto (PIB), Índice de Desenvolvimento Humano (IDH), entre outros aspectos conjugados.

Em continuidade, quanto à segunda condicionante, Márcia Miranda Soares concluiu que "há também caráter redistributivo nos repasses da União, privilegiando os Municípios mais pobres” (dimensão redistributiva), e, sob outra perspectiva,

67 SOARES, Márcia Miranda, cit., 307.

68 SOARES, Márcia Miranda, cit., p. 2. 
que "Municípios mais ricos, dotados de maior capacidade técnica, também foram beneficiados com estas transferências" (dimensão da eficiência). ${ }^{69}$ Dessa forma, os Municípios mais contemplados com o recebimento de transferências voluntárias foram, de um lado, aqueles com maior arrecadação tributária e, de outro lado, também os mais pobres, em uma clara manifestação conjunta das condicionantes técnica e redistributiva.

No aspecto técnico, os Municípios mais ricos estariam estruturalmente melhor preparados para a adoção dos procedimentos necessários ao recebimento dos recursos, inclusive porque esses mesmos Municípios são também os principais destinatários de investimentos em obras públicas. Ao contrário, sob o aspecto distributivo, soa lógico o maior benefício concedido aos Municípios mais carentes.

\subsection{MANOBRAS POLÍTICAS QUE ENVOLVEM A LIBERAÇÃO DE TRANSFERÊNCIAS VOLUNTÁRIAS}

Consoante já salientado, as transferências voluntárias apresentam forte conteúdo discricionário, sujeitando-se a acordos e articulações de cunho político para a sua consecução. Nesse ponto, distanciam-se das transferências obrigatórias, dada a ausência de maleabilidade conferida ao gestor para o implemento das últimas, assim como de condições para a sua realização, tendo em vista a necessidade de observância aos expressos termos legais ou constitucionais a que se encontram submetidas. Dessa forma, fica evidenciada certa "manipulação do orçamento" como forma de obter o apoio necessário para a adoção de medidas pelo Chefe do Poder Executivo, que muitas vezes necessita do apoio parlamentar para a garantia da própria governabilidade. Nesse sentido, destaca André Regis:

Desde a redemocratização de 1985, presidentes souberam manipular o orçamento federal para formar uma base de apoio na Câmara dos Deputados (Alston et al., 2004). Para isso, o Governo Federal contingencia parte dos recursos destinados a obras de interesse municipal, como hospitais, escolas e estradas, enquanto aguarda a aprovação de matérias de seu interesse no Congresso. Dada a fragmentação e fragilidade do sistema partidário nacional, não há outra maneira de proceder (Mainwaring, 1999; Desposato, 2002). ${ }^{70}$

Aponta, ainda, o autor, para as críticas daí advindas:

Esse tipo de relação entre o Presidente e o Congresso é severamente criticado pela imprensa e por analistas. Eles clamam por um verdadeiro orçamento, o que evitaria - ou ao menos reduziria - o favorecimento de deputados fiéis. Só que os presidentes

69 SOARES, Márcia Miranda, cit., p. 2.

70 REGIS, André. O novo federalismo brasileiro. Rio de Janeiro: Forense, 2009, p. 75. 
consideram que, sem esse mecanismo, sua governabilidade ficaria ameaçada. Além disso, como foi visto, as emendas de parlamentares respondem por cerca de $1 \%$ do orçamento. E, no final das contas, as obras pedidas são sempre necessárias, embora possa ser argumentado que sua prioridade é medida em termos dos votos para projetos tramitando no Congresso que elas possam trazer. ${ }^{71}$

Consoante tal raciocínio, a grande crítica sofrida pelas transferências voluntárias, no sentido da prevalência de critérios políticos para sua realização, acaba por revelar a real necessidade das obras e dos projetos por elas custeados. Com efeito, em uma escala de prioridades, é inevitável que o critério subjetivo do administrador, no âmbito da esfera de sua discricionariedade, determine quais serão as medidas a serem priorizadas. Trata-se, assim, de "crítica" aplicável a toda a atividade administrativa, não restrita apenas ao âmbito das transferências voluntárias. Nesse sentido, a objeção seria equivalente a questionar-se o administrador sobre a razão pela qual ele escolheu construir na região um hospital ou uma creche, ou então por que construiu um hospital no Município X e não no Município Y, quando ambos necessitavam dos mencionados estabelecimentos. Ambas as situações resvalam na discricionariedade da gestão administrativa, reforçada, no caso das transferências voluntárias, pela escassez dos recursos financeiros.

De outra sorte, enquanto argumento contrário ao manejo político do orçamento, observa-se que o ente federado, em especial os Municípios, que não disponha de força política suficiente para as manobras político-orçamentárias pode ficar alijado do processo de transferências de recursos. Essa situação revela claramente a falha no sistema, sendo justificáveis as críticas por ele sofridas quanto a esse aspecto.

Aponta ainda o autor que as manobras orçamentárias acabam inclusive delegando importância secundária à atividade legislativa propriamente dita:

Nesse caso, a cooperação dos líderes dos partidos da base aliada é fundamental. Eles são os responsáveis pela negociação entre os deputados e a Secretaria Geral da Presidência, órgão que busca apoio ao governo em troca de verba para obras públicas. No tempo de FHC, essa secretaria tinha uma lista de deputados e suas demandas, o que facilitava as negociações. Ivan Valente, deputado do PSOL, disse uma vez que essas negociações eram cruciais para as carreiras dos deputados. Isso explicaria porque eles têm menos interesse em legislar do que em obter recursos para as prefeituras que controlam, o que persiste até hoje. ${ }^{72}$

André Regis apresenta, ainda, um interessante quadro que retrata as relações entre os Poderes Executivo e Legislativo no processo de transferências voluntárias, e o momento em que se manifestariam de forma mais intensa os chamados "processos de barganha".

71 REGIS, André, cit., p. 75.

72 REGIS, André, cit., p. 75. 
Quadro 6.7 Relações entre os Poderes Executivo e Legislativo no processo de transferências voluntárias, segundo momentos de barganha

\begin{tabular}{|c|l|l|}
\hline ETAPA & \multicolumn{1}{|c|}{ DETALHES } & \multicolumn{1}{|c|}{ PROCESSOS DE BARGANHA } \\
\hline $\mathbf{1}^{\mathbf{a}}$ & $\begin{array}{l}\text { Proposta de orçamento } \\
\text { (encaminhada pelo Presidente ao Congresso) }\end{array}$ & \\
\hline $\mathbf{2}^{\mathbf{a}}$ & Análise da proposta pela Comissão de Orçamento & \\
\hline $\mathbf{3}^{\mathbf{a}}$ & Inclusão de emendas parlamentares & Influência de prefeitos e lobistas \\
\hline $\mathbf{4}^{\mathbf{a}}$ & Aprovação pelo Congresso & \\
\hline $\mathbf{5}^{\mathbf{a}}$ & $\begin{array}{l}\text { Retenção de recursos para emendas } \\
\text { parlamentares (transferências voluntárias) }\end{array}$ & $\begin{array}{l}\text { Liberação parcial de emendas parlamentares, } \\
\text { sujeita à aprovação de projetos e emendas } \\
\text { propostas pelo Executivo }\end{array}$ \\
\hline $\mathbf{6}^{\mathbf{a}}$ & Execução & \multicolumn{2}{c}{} \\
\hline
\end{tabular}

Fonte: $\quad$ REGIS, André, cit., p. 76.

Verifica-se, assim, que as fases em que a influência político-partidária mais se manifesta nas relações estabelecidas entre os Poderes Legislativo e Executivo ocorrem tanto no curso do processo legislativo, mais especificamente na fase de inclusão de emendas, quanto no momento da execução orçamentária, especialmente na fase de liberação parcial das emendas.

Nesse ponto, é relevante a inovação das emendas ao orçamento de execução obrigatória, instituídas pela Emenda Constitucional n. 86/2015, que acabou por coibir a utilização de mecanismos de barganha com o Poder Executivo para a implementação das emendas de autoria parlamentar, impondo a obrigatoriedade de sua efetivação. Nessa medida, resta induvidoso que a concretização das transferências voluntárias decorrentes de emendas parlamentares sofreu substancial alteração, exigindo a realização de uma análise mais acurada acerca da alteração de seu regime jurídico.

\subsection{INOVAÇÕES INTRODUZIDAS PELA EMENDA CONSTITUCIONAL N. 86/2015: ORÇAMENTO IMPOSITIVO DAS EMENDAS INDIVIDUAIS}

A Emenda Constitucional n. 86/2015 introduziu relevantes alterações na sistemática orçamentária brasileira, com influência direta na operacionalização das transferências voluntárias de recursos veiculadas por emendas parlamentares. Essas mudanças foram motivadas, essencialmente, pelo descontentamento parlamentar com os baixos níveis de execução orçamentária e financeira das emendas individuais. ${ }^{73}$

73 BRASIL. Congresso Nacional, Consultoria de Orçamentos, Fiscalização e Controle - Senado Federal, Consultoria de Orçamentos, Fiscalização e Controle - Câmara dos Deputados. Estudo Técnico Conjunto n. 1, de 2015: O regime do orçamento impositivo das emendas individuais 
Assim, a alteração no texto constitucional foi aprovada com o fim de conferir efetividade às emendas parlamentares individuais aprovadas pelo Poder Legislativo e inseridas na lei orçamentária. Visava a retirar da esfera do Poder Executivo o poder decisório sobre a execução de determinadas políticas públicas e suas correspondentes despesas autorizadas no orçamento, que não mais estariam sujeitas ao crivo da discricionariedade do Chefe do Poder Executivo.

Conforme salientado, a medida acaba produzindo reflexos diretos na sistemática das transferências voluntárias, que têm como um dos pilares justamente os repasses de recursos previstos e autorizados pelas emendas parlamentares. Ao se conferir o caráter obrigatório à execução das medidas previstas nas emendas, o poder de negociação e troca de apoio político restaram altamente comprometidos.

Embora seja inovação introduzida na esfera constitucional, porém, já contava com previsão no ordenamento jurídico nacional, especialmente trazida pelas Leis de Diretrizes Orçamentárias da União para os exercícios de 2014 e 2015. A Emenda Constitucional n. 86 atuou para conferir nova redação aos artigos 165, 166 e 198 da Constituição Federal, interessando-nos mais de perto as alterações efetuadas nos artigos $165, \$ 9^{\circ}$, inciso III, e $166, \$ \$ 9^{\circ}$ a 18 , acrescentados ao texto constitucional, com a seguinte redação:

Art. 165. Leis de iniciativa do Poder Executivo estabelecerão:

(...)

$\$ 9^{\circ}$ Cabe à lei complementar:

I - dispor sobre o exercício financeiro, a vigência, os prazos, a elaboração e a organização do plano plurianual, da lei de diretrizes orçamentárias e da lei orçamentária anual;

II - estabelecer normas de gestão financeira e patrimonial da administração direta e indireta bem como condições para a instituição e funcionamento de fundos.

III - dispor sobre critérios para a execução equitativa, além de procedimentos que serão adotados quando houver impedimentos legais e técnicos, cumprimento de restos a pagar e limitação das programações de caráter obrigatório, para a realização do disposto no $₫ 11$ do art. 166 .

Art. 166. (...)

$\$ 9^{\circ}$ As emendas individuais ao projeto de lei orçamentária serão aprovadas no limite de $\mathbf{1 , 2} \%$ (um inteiro e dois décimos por cento) da receita corrente líquida pre-

- disposições da Emenda Constitucional n. 86, de 2015, e da LDO 2015. Brasília: Congresso Nacional, 2015, p. 4. 
vista no projeto encaminhado pelo Poder Executivo, sendo que a metade deste percentual será destinada a ações e serviços públicos de saúde.

$\$ 10$. A execução do montante destinado a ações e serviços públicos de saúde previsto no $\$ 9^{\circ}$, inclusive custeio, será computada para fins do cumprimento do inciso I do $\$ 2^{\circ}$ do art. 198, vedada a destinação para pagamento de pessoal ou encargos sociais.

$\$ 11$. É obrigatória a execução orçamentária e financeira das programações a que se refere o $\$ 9^{\circ}$ deste artigo, em montante correspondente a 1,2\% (um inteiro e dois décimos por cento) da receita corrente líquida realizada no exercício anterior, conforme os critérios para a execução equitativa da programação definidos na lei complementar prevista no $\$ 9^{\circ}$ do art. 165 .

$\$ 12$. As programações orçamentárias previstas no $\$ 9^{\circ}$ deste artigo não serão de execução obrigatória nos casos dos impedimentos de ordem técnica.

$\$ 13$. Quando a transferência obrigatória da União, para a execução da programação prevista no $\$ 11$ deste artigo, for destinada a Estados, ao Distrito Federal e a Municípios, independerá da adimplência do ente federativo destinatário e não integrará a base de cálculo da receita corrente líquida para fins de aplicação dos limites de despesa de pessoal de que trata o caput do art. 169.

$\$ 14$. No caso de impedimento de ordem técnica, no empenho de despesa que integre a programação, na forma do $\$ 11$ deste artigo, serão adotadas as seguintes medidas:

I - até 120 (cento e vinte) dias após a publicação da lei orçamentária, o Poder Executivo, o Poder Legislativo, o Poder Judiciário, o Ministério Público e a Defensoria Pública enviarão ao Poder Legislativo as justificativas do impedimento;

II - até 30 (trinta) dias após o término do prazo previsto no inciso I, o Poder Legislativo indicará ao Poder Executivo o remanejamento da programação cujo impedimento seja insuperável;

III - até 30 de setembro ou até 30 (trinta) dias após o prazo previsto no inciso II, o Poder Executivo encaminhará projeto de lei sobre o remanejamento da programação cujo impedimento seja insuperável;

IV - se, até 20 de novembro ou até 30 (trinta) dias após o término do prazo previsto no inciso III, o Congresso Nacional não deliberar sobre o projeto, o remanejamento será implementado por ato do Poder Executivo, nos termos previstos na lei orçamentária.

$\$ 15$. Após o prazo previsto no inciso IV do $\$ 14$, as programações orçamentárias previstas no $₫ 11$ não serão de execução obrigatória nos casos dos impedimentos justificados na notificação prevista no inciso I do $\$ 14$.

$\$ 16$. Os restos a pagar poderão ser considerados para fins de cumprimento da execução financeira prevista no $₫ 11$ deste artigo, até o limite de $\mathbf{0 , 6 \%}$ (seis décimos por cento) da receita corrente líquida realizada no exercício anterior.

$\$ 17$. Se for verificado que a reestimativa da receita e da despesa poderá resultar no não cumprimento da meta de resultado fiscal estabelecida na lei de diretrizes orçamentárias, 
o montante previsto no $₫ 11$ deste artigo poderá ser reduzido em até a mesma proporção da limitação incidente sobre o conjunto das despesas discricionárias.

$\$ 18$. Considera-se equitativa a execução das programações de caráter obrigatório que atenda de forma igualitária e impessoal às emendas apresentadas, independentemente da autoria. (Grifo nosso)

Assim, a execução das programações incluídas ou acrescidas por meio de emendas parlamentares individuais passaram a dispor de caráter compulsório, que somente pode ser afastado em decorrência de impedimentos técnicos ou legais.

Se, por um lado, é patente o fortalecimento das prerrogativas parlamentares, no sentido da garantia de execução das emendas de autoria parlamentar, por outro lado ressalta-se a criação de um limite à própria atuação parlamentar, mediante a inserção constitucional de um teto à aprovação de emendas individuais, fixado no percentual de $1,2 \%$ da receita corrente líquida prevista no projeto encaminhado pelo Poder Executivo. Trata-se indubitavelmente de uma restrição à prerrogativa conferida aos parlamentares de apresentação e aprovação de emendas ao projeto de lei orçamentária.

Nesse sentido, ressaltam Eugênio Greggianin e José de Ribamar Pereira da Silva, em estudo técnico elaborado no âmbito do Congresso Nacional acerca do regime impositivo das emendas individuais:

A inclusão no texto constitucional de parâmetro financeiro à aprovação de emendas individuais visou evitar que, em decorrência da aprovação do orçamento impositivo, houvesse o aumento descontrolado das programações aprovadas por emendas individuais. Tal limite era, até então, fixado apenas no parecer preliminar da LOA, em atendimento ao art. 49 da Resolução n. 1, de 2006 - CN (CONGRESSO NACIONAL, 2006), e poderia haver estímulo ao aumento desse limite por mera deliberação da CMO, uma vez que a execução das emendas se tornou obrigatória.

Por outro lado, trata-se de renúncia de prerrogativa pública, uma vez que impede a ação individual do parlamentar de propor alteraçóes estruturantes e de maior repercussão financeira na peça orçamentária, as quais serão previamente inadmitidas, independentemente de seu mérito. ${ }^{74}$ (Grifo nosso)

Dentro do limite fixado, $50 \%$ do valor das emendas deverão ser destinados a ações e serviços públicos de saúde, computando-se este valor para o cálculo da aplicação mínima de recursos na área da saúde pelo ente federado. Nesse sentido, os mesmos autores pontuam:

Observa-se que o objeto das programaçôes incluídas por emendas individuais na área de saúde é constituído, em geral, por demandas eletivas, específicas e localizadas

74 BRASIL. Congresso Nacional, Consultoria de Orçamentos, Fiscalização e Controle - Senado Federal, Consultoria de Orçamentos, Fiscalização e Controle - Câmara dos Deputados, cit., p. 7-8. Grifo nosso. 
(transferências voluntárias), que nem sempre possuem o atributo de universalidade e generalidade exigido das programações destinadas ao atendimento do sistema de saúde pública. ${ }^{75}$

Da análise do texto constitucional, sobressai, ainda, a diferenciação contida na redação dos $\$ \$ 9^{\circ}$ e 11 do artigo 166 quanto aos parâmetros adotados para a aprovação e para a execução das emendas parlamentares. Enquanto o $₫ 9^{\circ}$ estabelece como limite de aprovação das emendas o percentual de 1,2\% (um inteiro e dois décimos por cento) da receita corrente líquida prevista no projeto encaminhado pelo Poder Executivo, o $₫ 11$ torna obrigatória a execução orçamentária e financeira das programaçóes a que se refere o $\$ 9^{\circ}$ do mesmo artigo, em montante correspondente a 1,2\% (um inteiro e dois décimos por cento) da receita corrente líquida realizada no exercício anterior. Quanto a esse aspecto, alertam Eugênio Greggianin e José de Ribamar Pereira da Silva para as consequências da fixação de diferentes parâmetros de aprovação e execução das emendas:

O uso de diferentes bases de cálculo para a aprovação das emendas e para a execução, inspirado inicialmente em uma espécie de seguro contra a frustração da receita prevista na LOA, revelou-se inapropriado. Havendo acréscimo da RCL no exercício seguinte, o mesmo não é aproveitado pelas emendas, em função do limite de aprovação; e, havendo decréscimo da RCL no exercício em curso, a parcela frustrada implicará contingenciamento de emendas. ${ }^{76}$

O percentual de 1,2\% da receita corrente líquida realizada no exercício anterior poderá ser integrado parcialmente por restos a pagar inscritos em exercícios anteriores, conforme a dicção do $\$ 16$ do artigo 166. A possibilidade é justificada pela grande quantidade de recursos empenhados e não pagos no exercício financeiro respectivo. A esse propósito, aludem os autores:

Os restos a pagar existem porque grande parte dos empreendimentos tem execução prolongada no tempo. Além disso, durante a execução física das programaçōes, interferências e adiamentos podem afetar a gestão e o cumprimento do cronograma original, atrasando-se o recebimento de bens e serviços, o que, por consequência, atrasa os pagamentos. ${ }^{77}$

Como contraponto às emendas de execução obrigatória, a nova sistemática previu a possibilidade de afastamento da compulsoriedade diante da ocorrência de impedimentos de ordem técnica. A previsão legitima de forma expressa a não

75 BRASIL. Congresso Nacional, Consultoria de Orçamentos, Fiscalização e Controle - Senado Federal, Consultoria de Orçamentos, Fiscalização e Controle - Câmara dos Deputados, cit., p. 8.

76 BRASIL. Congresso Nacional, Consultoria de Orçamentos, Fiscalização e Controle - Senado Federal, Consultoria de Orçamentos, Fiscalização e Controle - Câmara dos Deputados, cit., p. 11.

77 BRASIL. Congresso Nacional, Consultoria de Orçamentos, Fiscalização e Controle - Senado Federal, Consultoria de Orçamentos, Fiscalização e Controle - Câmara dos Deputados, cit., p. 16. 
observância das emendas diante da ocorrência de ilegalidade ou vícios de naturezas diversas. A título de exemplo, a Portaria Interministerial n. 40/14, que "disciplina a utilização do Sistema de Gestão de Convênios e Contratos de Repasse - SICONV para a celebração de convênios e contratos de repasse objetivando a execução obrigatória das emendas parlamentares individuais de que trata o art. 52 da Lei n. 12.919 , de 2013 " contém, em seu artigo $2^{\circ}$, elenco exemplificativo de possíveis impedimentos de ordem técnica obstativos da execução obrigatória das emendas:

Art. 20 Os órgãos e entidades da Administração Pública Federal integrantes do Orçamento Fiscal e da Seguridade Social da União deverão analisar a proposta e o plano de trabalho apresentados, conforme o disposto nos arts. 25 e 26 da Portaria Interministerial n. 507, de 24 de novembro de 2011, de modo a verificar a existência de impedimento de ordem técnica no prazo previsto no inciso I do $\$ 2^{\circ}$ do art. 52 da Lei $n$. 12.919, de 2013 .

$\$ 1^{\circ}$ Serão considerados impedimentos de ordem técnica:

I - a não indicação do beneficiário e do valor da emenda nos prazos estabelecidos nesta Portaria;

II - a não apresentação do plano de trabalho no prazo previsto no inciso IV do art. $4^{\circ}$ ou não realização da complementação e dos ajustes solicitados no plano de trabalho no prazo previsto no inciso VI do art. $4^{\circ}$;

III - a desistência da proposta por parte do proponente;

IV - a incompatibilidade do objeto proposto com a finalidade da ação orçamentária;

$\mathrm{V}$ - a incompatibilidade do objeto proposto com o programa do órgão ou entidade executora;

VI - a falta de razoabilidade do valor proposto, a incompatibilidade do valor proposto com o cronograma de execução do projeto ou proposta de valor que impeça a conclusão de uma etapa útil do projeto;

VII - a não aprovação do plano de trabalho; e

VIII - outras razões de ordem técnica, devidamente justificadas.

Diante da constatação de uma das hipóteses de impedimento, a própria emenda estabelece o procedimento a ser adotado com o objetivo de suprimir o vício ou remanejar a despesa. Nessa medida, os Poderes responsáveis pela execução da despesa enviarão as justificativas do impedimento, no prazo de 120 dias, ao Poder Legislativo, que dispõe do prazo de 30 dias para indicar ao Poder Executivo o remanejamento da programação. Deve o último, por sua vez, encaminhar, no prazo de 30 dias ou até o dia 30 de setembro, projeto de lei sobre o remanejamento. Dispõe o inciso IV que, se o Poder Legislativo não deliberar sobre o projeto no prazo previsto, o remanejamento será implementado pelo Poder Executivo. 
Assim, caracterizando-se o impedimento como insuperável, deve-se proceder ao remanejamento da despesa, na forma prevista no $\$ 14$ do artigo 166 da Constituição Federal. Nesse aspecto, aponta Fernando Facury Scaff para a caracterização de um paradoxo, na medida em que, não obstante o contexto da legalidade que rege o sistema orçamentário, o remanejamento deve se operar independentemente da existência de lei. $\mathrm{O}$ autor destaca, nesse contexto, outra hipótese de exceção ao caráter impositivo das emendas:

Supondo que o Congresso não delibere acerca desse tema em 30 dias, ou até a data de 20 de novembro, o remanejamento proposto pelo Legislativo deverá ser implementado por ato do Poder Executivo, nos termos previstos na lei orçamentária. Aparentemente se tem uma situação paradoxal, pois a norma menciona que se deve implementar o remanejamento, mesmo que não haja lei nesse sentido, o que subverte todo o sentido de respeito ao sistema de legalidade existente no âmbito orçamentário pela Carta de 1988 e se trata de uma inovação dessa Emenda Constitucional (artigo 166, $\$ 14, \mathrm{IV})$. A forma de compreensão desse aparente paradoxo é explicitada pelo artigo $166, \$ 15$, que menciona que essa verba deixa de ser obrigatória, findo o prazo estabelecido para a deliberação do Parlamento. Ou seja, o que era uma despesa obrigatória tornou-se despesa discricionária findo o prazo referido. ${ }^{78}$

Os impedimentos técnicos não se confundem com o contingenciamento, que apenas suspende a exequibilidade da despesa, sendo aplicado de forma genérica. A diferenciação também foi objeto de análise no estudo técnico anteriormente mencionado:

Não existe, do ponto de vista formal, contingenciamento de dotaçôes específicas no âmbito dos orçamentos da União, nos termos dos decretos de contingenciamento até hoje aprovados. Os contingenciamentos são estabelecidos e geridos na forma de limites globais de empenho, por órgão. Cada órgão define em seu âmbito a incidência do contingenciamento por programação.

De forma diversa, os impedimentos são específicos e caracterizados para cada programação. Neste sentido, o inciso I acima distingue os institutos, sendo que os contingenciamentos apenas suspendem, mas não impedem a execução posterior. Os impedimentos devem ser verificados independentemente da existência de limites que permitam o empenho. ${ }^{79}$

$\mathrm{O} \$ 17$ do artigo 166 inseriu expressamente a possibilidade de contingenciamento das emendas individuais, não obstante o caráter obrigatório atribuído pela Emenda Constitucional n. 86/15. Essa ação, no entanto, deve ser efetuada de forma proporcional à limitação incidente sobre as demais despesas de caráter discricionário.

78 SCAFF, Fernando Facury. Surge o orçamento impositivo à brasileira pela Emenda Constitucional 86. Consultor Jurídico, 24 março 2015.

79 BRASIL. Congresso Nacional, Consultoria de Orçamentos, Fiscalização e Controle - Senado Federal, Consultoria de Orçamentos, Fiscalização e Controle - Câmara dos Deputados, cit., p. 28. 
Ao discorrermos sobre os mecanismos de flexibilidade orçamentária à disposição do Chefe do Poder Executivo, assim nos manifestamos acerca do contingenciamento em trabalho anterior:

Também conhecido por limitação de empenho, constitui o contingenciamento mecanismo de flexibilidade orçamentária que permite ao Poder Executivo deixar de realizar certas despesas em virtude da ausência de recursos voltados à sua consecução, decorrente essencialmente da arrecadação de receitas em montante inferior àquele inicialmente previsto na lei orçamentária anual.

Não apenas a arrecadação de receitas a menor, mas também outros fatores podem levar à necessidade de alteração da programação orçamentária, tais como problemas econômicos, erros de planejamento, ausência de uma disponibilidade financeira que não se confirmou, constatação de que determinada despesa prevista no orçamento não atendia ao princípio da economicidade e até mesmo a mudança de prioridades, desde que também inseridas no plano de governo.

Algumas despesas não são passíveis de limitação, tal como excepcionado pelo $\$ 2^{\circ}$ do artigo $9^{\circ}$ da LRF, que afasta de sua incidência as despesas que constituam obrigaçōes constitucionais ou legais do ente, inclusive aquelas destinadas ao pagamento do serviço da dívida, as que disponham de natureza obrigatória e as ressalvadas pela lei de diretrizes orçamentárias. ${ }^{80}$

Dessa forma, ainda que as emendas parlamentares disponham da natureza impositiva conferida pela emenda constitucional, as despesas nelas contidas sujeitam-se ao contingenciamento, nos moldes dispostos no $\$ 17$, contrariamente ao regime das despesas obrigatórias, que não se sujeitam à limitação analisada. Observa Fernando Scaff que essa possibilidade de contingenciamento busca preservar, em última análise, os interesses dos credores públicos:

Esta vinculação de 1,2\% poderá ser contingenciada, na forma do artigo $9^{\circ}$ da Lei de Responsabilidade Fiscal, caso haja ameaça do descumprimento da meta de superavit primário estabelecido no anexo de metas fiscais da Lei de Diretrizes Orçamentárias, o que demonstra que até mesmo os interesses eleitorais cessam quando entra em questão o pagamento dos credores públicos (artigo 166, \$17). ${ }^{81}$

Assim, não obstante o reconhecimento expresso do caráter obrigatório quanto à execução das emendas parlamentares, prevalece o critério proporcional de contingenciamento característico das despesas de caráter discricionário. Com efeito, especificamente no tocante às emendas parlamentares destinadas aos Estados e Municípios, tradicionalmente veiculadoras das transferências voluntárias de recursos financeiros entre os entes da federação, a nova previsão constitucional foi categórica

80 DALLAVERDE, Alexsandra Katia, cit., p. 135-136.

81 SCAFF, Fernando Facury, cit. 
ao defini-las enquanto transferências obrigatórias, afastando-as da exigência de comprovação da regularidade quanto às obrigações fiscais do beneficiário, na medida em que o próprio $\$ 13$ estabelece que a transferência “independerá da adimplência do ente federativo destinatário e não integrará a base de cálculo da receita corrente líquida para fins de aplicação dos limites de despesa de pessoal de que trata o caput do art. 169".

Assim, os requisitos formais a serem observados pelos entes federados para o recebimento das transferências voluntárias foram dispensados na hipótese de emenda de execução obrigatória. O dispositivo esclarece, no entanto, que a transferência não integrará a base de cálculo da receita corrente líquida para fins de cálculo dos limites de despesas com pessoal, na forma do disposto no caput do artigo 169, segundo o qual "a despesa com pessoal ativo e inativo da União, dos Estados, do Distrito Federal e dos Municípios não poderá exceder os limites estabelecidos em lei complementar".

No caso, a lei complementar referida no dispositivo é a Lei de Responsabilidade Fiscal (Lei Complementar n. 101/2000), que fixa os limites de gasto com pessoal com base na receita corrente líquida, conforme disposto no caput do artigo 19:

Art. 19. Para os fins do disposto no caput do art. 169 da Constituição, a despesa total com pessoal, em cada período de apuração e em cada ente da Federação, não poderá exceder os percentuais da receita corrente líquida, a seguir discriminados:

I - União: 50\% (cinqüenta por cento);

II - Estados: 60\% (sessenta por cento);

III - Municípios: 60\% (sessenta por cento).

Trata-se, assim, de figura híbrida que se sujeita ao regime das transferências obrigatórias, mas com ressalvas pontuais, como a possibilidade de contingenciamento nos limites das demais despesas discricionárias e de remanejamento das despesas em observância ao $\$ 14$ do artigo 166 .

Outro ponto importante introduzido pela Emenda Constitucional n. 86/15 refere-se ao critério de execução equitativa das programações incluídas pelas emendas, assim entendida aquela "que atenda de forma igualitária e impessoal às emendas apresentadas, independentemente da autoria", atentando-se, para tais fins, à interpretação conjunta do disposto nos $\$ \$ 11$ e 18 do artigo 166:

$\$ 11$ É obrigatória a execução orçamentária e financeira das programações a que se refere o $\$ 9^{\circ}$ deste artigo, em montante correspondente a 1,2\% (um inteiro e dois décimos por cento) da receita corrente líquida realizada no exercício anterior, conforme os critérios para a execução equitativa da programação definidos na lei complementar prevista no $\$ 9^{\circ}$ do art. 165 . 
$\$ 18$ Considera-se equitativa a execução das programações de caráter obrigatório que atenda de forma igualitária e impessoal às emendas apresentadas, independentemente da autoria.

Os critérios para a execução equitativa deverão ser veiculados por lei complementar, conforme previsão do artigo $165, \$ 9^{\circ}$, que já indica uma série de questões a serem abordadas pelo referido instrumento, devendo-se acrescentar ao rol do mencionado parágrafo a definição dos critérios reclamados pelo $\$ 11$ do artigo 166 .

A grande influência da alteração da sistemática das emendas parlamentares sobre a realização de transferências voluntárias decorre essencialmente do fato de que as emendas deixarão de constituir moeda de troca entre os Poderes Legislativo e Executivo, em razão da garantia jurídica da execução das emendas, independentemente de uma atuação parlamentar condizente ou não aos interesses do Poder Executivo. Contudo, consoante aponta Fernando Facury Scaff, a impositividade conferida às emendas não terá o condão de afastar o domínio que o Poder Executivo exerce sobre o orçamento. Nesse sentido, pontua o eminente professor:

O fato é que foi criada pela EC 86 - além dessa vinculação para a saúde - um modelo de Orçamento impositivo à brasileira, onde apenas as dotaçôes orçamentárias para emendas parlamentares se tornaram impositivas, mas o restante permanece ao bel prazer de quem tem tinta na caneta, ou seja, o Poder Executivo, o que bem demonstra a permanência do modelo de presidencialismo imperial vigente no Brasil. ${ }^{82}$

$\mathrm{O}$ eventual afastamento das emendas enquanto moeda de troca também gera preocupação em alguns estudiosos, como Vander Gontijo, especialmente em relação ao desenvolvimento de outros mecanismos de negociação entre os Poderes:

O argumento de que isso é necessário para evitar negociação com a Casa Civil é controverso. Negociar é elemento intrínseco à função política. Ora, se a emenda não for o referencial para a negociação, outra moeda de troca haverá. Talvez até com menor transparência. Aliás, a negociação que se encontrava restrita à Casa Civil ocupará novos espaços. Ampliar-se-á o campo de barganha do parlamentar que agora pode exibir a governadores e prefeitos uma garantia constitucional no cheque emitido pelo Tesouro Nacional! ${ }^{83}$

De qualquer forma, sendo certo que a instituição das emendas de execução impositiva irá ocasionar mudanças no relacionamento entre os Poderes, a verificação quanto às consequências práticas e alterações no quadro de negociações políticas que envolvem os instrumentos de flexibilidade orçamentárias do Poder Executivo demandará grande atenção por parte dos estudiosos do tema.

82 SCAFF, Fernando Facury, cit.

83 GONTIJO, Vander. Um tiro no pé dos congressistas. Gazeta do Povo, 31 maio 2014. 


\subsection{AS TRANSFERÊNCIAS VOLUNTÁRIAS EM UMA PERSPECTIVA ELEITORAL - A TEORIA DA CONEXÃO ELEITORAL}

Quando se aborda o aspecto político das transferências voluntárias, merece menção a chamada "Teoria da Conexão Eleitoral", desenvolvida por David Mayhew, segundo a qual toda a atividade desenvolvida pelos parlamentares busca, em última instância, a reeleição. A respeito da conexão entre a atuação parlamentar e o objetivo eleitoral pontua o autor:

Whether they are safe or marginal, cautions or audacious, congressmen must constantly engage in activities related to reelection. There will be differences in emphasis, but all members share the root need to do things - indeed, to do things day in and day out during their terms. The next step here is to present a typology, a short list of the kinds of activities congressmen find it electorally useful to engage in. ${ }^{84}$

Apoiada na doutrina de Mayhew, Ivanete de Araújo Costa chama atenção para algumas ações que seriam imprescindíveis ao alcance do objetivo traçado, com especial destaque para: a) a publicidade das açóes parlamentares; b) a busca do crédito, de recursos para a consecução das necessidades da comunidade, que se faz essencialmente por meio da apresentação de emendas parlamentares; e c) a tomada de posição, no sentido da necessidade do parlamentar manifestar-se publicamente sobre assuntos de interesse público, seja por meio da própria atuação parlamentar - discursos em plenário ou comissões -, seja por meio de depoimentos divulgados pela mídia. ${ }^{85}$

Assim, a primeira das ações voltadas para o alcance do objetivo é denominada por David Mayhew de advertising (propaganda), caracterizada pela publicidade da figura do parlamentar focada em suas qualidades pessoais e desvinculada de posicionamentos ideológicos ou partidários. Nessa medida, estatui o autor:

One activity is advertising, defined here as any effort to disseminate one's name among constituents in such a fashion as to create a favorable image but in messages

84 MAYHEW, David R. Congress - the electoral connection. New Haven; London: Yale University Press, 1974, p. 49. Tradução nossa: "Se elas são seguras ou marginais, cuidadosas ou audaciosas, congressistas devem constantemente se engajar em atividades relacionadas à reeleição. Haverá diferenças na ênfase, mas todos os membros compartilham a necessidade básica de fazer coisas - de fato, fazer coisas dia vai, dia vem, durante seus mandatos. O próximo passo aqui é apresentar uma tipologia, uma pequena lista de tipos de atividades que os congressistas acham eleitoralmente úteis para se engajar".

85 COSTA, Ivanete de Araújo. Conexão eleitoral: a reeleição na Câmara dos Deputados e o perfil político dos parlamentares com oito ou mais mandatos consecutivos. 47f. Monografia (especialização) - Centro de Formação, Treinamento e Aperfeiçoamento (Cefor), Câmara dos Deputados, 2007. 
having little or no issue content. A successful congressman builds what amounts to a brand name, which may have a generalized electoral value for other politicians in the same family. The personal qualities to emphasize are experience, knowledge, responsiveness, concern, sincerity, independence, and the like. Just getting one's name across is difficult enough; only about half of electorate, if asked, can supply their House members' names. It helps a congressman to be known (...). ${ }^{86}$

A segunda forma de obtenção de sucesso do parlamentar em novo certame eleitoral consiste no chamado credit claiming (reivindicação de crédito), método segundo o qual o parlamentar busca transmitir ao seu eleitorado a expectativa da defesa de seus interesses, sejam individuais, sejam relativos ao grupo a que pertencem, gerando nos eleitores o desejo de manter o político no exercício do encargo para a defesa desses interesses. Nesse sentido, define o autor:

A second activity may be called credit claiming, defined here as acting so as to generate a belief in a relevant political actor (or actors) that one is personally responsible for causing the government, or some unit thereof, to do something that the actor (or actors) considers desirable. The political logic of this, from the congressman's point of view, is that an actor who believes that a member can make pleasing things happen will no doubt wish to keep him in office so that he can make pleasing things happen in the future. The emphasis here is on individual accomplishment (rather than, say, party or governmental accomplishment) and on the congressman as doer (rather than as, say, expounder of constituency views). Credit claiming is highly important to congressmen, with the consequence that much of congressional life is a relentless search for opportunities to engage in it. ${ }^{87}$

86 MAYHEW, David R., cit., p. 49. Tradução nossa: "Uma atividade é a propaganda, definida aqui como qualquer esforço para disseminar o nome de alugém dentre os representados de tal maneira que crie uma imagem favorável, mas em mensagens que tenham pouca ou nenhuma questão de conteúdo. Um congressista bem-sucedido constrói o que conta para um nome distintivo, que possa ter um valor eleitoral generalizado para outros políticos na mesma família. As qualidades pessoas a serem enfatizadas são experiência, conhecimento, responsividade, preocupação, sinceridade, independência e coisas assim. Apenas fazer o nome compreensível já é difícil o suficiente; somente cerca de metade do eleitorado, se questionado, pode fornecer os nomes de seus membros da Câmara. Isso ajuda o congressista a ser conhecido (...)".

87 MAYHEW, David R., cit., p. 52. Tradução nossa: "Uma segunda atividade pode ser chamada reivindicação do crédito, definida aqui como agir de forma tal a gerar uma crença num ator (ou atores) político relevante que alguém é pessoalmente responsável por dar causa ao governo, ou alguma unidade disso, por fazer algo que o ator (ou atores) considera desejável. A lógica política disso, do ponto de vista do congressista, é que um ator que acredita que um membro pode fazer coisas felizes acontecerem irá, sem dúvidas, desejar mantê-lo no cargo para que assim ele possa fazer coisas felizes acontecerem no futuro. A ênfase aqui recai sobre o êxito individual (ao invés de, diga-se, êxito do governo ou do partido) e sobre o congressitas como alguém que faz (ao invés de, diga-se, expressar as perspectivas dos representados). Reivindicação do crédito é enormemente importante para congressistas, com a consequência de que grande parte da vida no congresso é uma busca desenfreada por oportunidades para atuar nisso". 
É justamente no âmbito do credit claiming que se situam as emendas parlamentares e outros mecanismos voltados à obtenção de recursos destinados aos distritos eleitorais dos parlamentares. Constitui característica da atividade parlamentar uma atuação voltada - ainda que não exclusivamente - ao atendimento dos interesses de seus redutos eleitorais. Acerca da mencionada constatação, prossegue David Mayhew: "In recent years awards given under grant-in-aid programs have become more useful as they have become more numerous". 88

Em continuidade, a terceira forma de ação focada no intuito de reeleição consiste na tomada de posicionamento formal quanto a matéria de interesse público, seja de ordem social, seja de ordem política ou econômica, manifestação esta que pode se dar no exercício da atuação parlamentar propriamente dita ou fora dela. Nesse sentido, David Mayhew descreve a terceira forma de atuação voltada à reeleição: "The third activity congressmen engage in may be called position taking, defined here as the public enunciation of a judgmental statement on anything likely to be of interest to political actors" ${ }^{89}$

Sem a pretensão de aprofundar a discussão acerca da aplicação da teoria da conexão eleitoral no Brasil, haja vista constituir objeto de profunda discussão político-sociológica, trazemos apenas alguns posicionamentos levantados por Ivanete de Araújo Costa:

O cientista político Nelson Rojas de Carvalho avalia que a teoria da conexão eleitoral formulada por Mayhew encontra similitudes no Brasil e pode ajudar a compreender o funcionamento do Legislativo:

(...) identificamos tanto por meio de evidências atitudinais, como comportamentais, o impacto da origem geográfica dos deputados sobre o que passa no interior do Legislativo. Mostramos que os incentivos oriundos da arena eleitoral adentram os corredores do Congresso e validamos, assim, a adoção também entre nós da perspectiva da conexão eleitoral como uma das chaves para o entendimento do modus operandi do Legislativo Brasileiro. ${ }^{90}$

Em outra passagem, relata a autora:

Carlos Pereira e Lúcio Rennó (op. cit., 1998) não descartam a possibilidade de reeleição dos parlamentares que adotam estratégias nacionais, porém avaliam que suas

88 MAYHEW, David R., cit., p. 56. Tradução nossa: "Nos últimos anos, recompensas concedidas sob programas de subsídios tornaram-se mais úteis, ao se tornarem mais numerosas".

89 MAYHEW, David R., cit., p. 61. Tradução nossa: "A terceira atividade em que congressistas se engajam pode ser chamada tomada de posição, definida aqui como a enunciação pública de uma declaração avaliativa sobre qualquer coisa que possa ser do interesse dos atores politicos".

90 COSTA, Ivanete de Araújo, cit., p. 15. 
chances são menores. Entretanto, para terem sucesso deverão buscar um meio de estar sempre na mídia, com a necessidade de criar fatos que agucem o interesse, levando em conta que tais fatos têm de estar ligados com sua base eleitoral. Do contrário, não surtirão efeito. Estar na mídia, simplesmente, pode não trazer ganhos.

Quanto à questão da busca de crédito pela ação junto ao Executivo, os autores sugerem que não basta ao parlamentar incluir emendas de sua autoria no Orçamento, até porque inclusão, tão somente, não assegura liberação. A apresentação de emenda ao Orçamento depende da vontade do parlamentar, obviamente, seguindo as regras, até mesmo com impedimento de apresentá-las, ou limites quanto a valores e quantidades.

Mais importante do que a apresentação de emendas é a liberação de recursos, tarefa muito difícil até mesmo para quem trabalha na base de apoio ao governo. Nesse sentido, a liberação dos recursos e a execução de projetos locais se tornam fundamentais para o sucesso eleitoral do candidato. ${ }^{11}$

Analisando o conteúdo das leis aprovadas pelo Legislativo, Paolo Ricci retorna ao conceito de políticas pork barrel, voltadas ao objetivo de reeleição dos parlamentares que visam à obtenção de benefícios para os respectivos distritos eleitorais através do exercício da atividade legislativa. A propósito do tema, elucida o autor:

Geralmente referenciados nos estudos sobre o Congresso americano, e portanto baseados na premissa de que o objetivo primário dos políticos é se reeleger, muitos autores argumentam que a estratégia legislativa conducente ao alcance de um objetivo desse tipo se restringe à adoção de políticas de pork barrel (Mayhew, 1974), isto é, políticas distributivas que buscam dispensar benefícios concentrados no distrito de eleição de cada deputado - benefícios estes cujos custos recaem, de forma imperceptível, sobre a sociedade como um todo. Essa estratégia dependeria crucialmente do incentivo presente na estrutura da competição eleitoral norte-americana, na qual a escolha dos representantes ocorre em colégios uninominais e com voto uninominal em turno único. ${ }^{92}$

Ressalte-se que, de acordo com a perspectiva analisada, as transferências voluntárias poderão ou não estar inseridas nesse contexto. A conclusão parece ser casuística, visto que determinada transferência pode ser efetivada levando-se em conta critérios objetivos de melhor distribuição de recursos públicos, com foco no desenvolvimento de regiões menos favorecidas, e, paralelamente, acarretar benefícios eleitorais. Esse não constitui, porém, o foco de análise das transferências Pork Barrel $^{93}$ americanas, adstritas efetivamente aos resultados eleitorais. Como aponta

91 COSTA, Ivanete de Araújo, cit., p. 17.

92 RICCI, Paolo. O conteúdo da produção legislativa brasileira: leis nacionais ou políticas paroquiais? DADOS - Revista de Ciências Sociais, Rio de Janeiro, v. 46, n. 4, p. 699-734, 2003.

93 Conforme definição trazida por José Antonio Meyer, citando Mccain, “'Pork barrel' is a term used to describe government sponsored (funded) projects that provide benefits for a particular congressional district or state and that have the added effect of helping an elected official win 
Paolo Ricci, sobre a ausência de uniformidade de entendimento doutrinário acerca da adoção da teoria no Brasil:

Ao se examinar os estudos realizados sobre o desempenho das instituiçôes brasileiras, verifica-se que são muitos os autores que importam o modelo americano (...). Dessa forma, várias análises argumentam que a prática legislativa dos deputados brasileiros é voltada para a adoção de políticas com efeito circunscrito e limitado ao reduto eleitoral do legislador (...).

Sobretudo a partir de meados dos anos 90, observa-se uma certa relutância do mundo acadêmico brasileiro em aceitar integralmente essa orientação analítica. Duas questões emergiram. A primeira, referente a um problema conceitual; a segunda, a um problema empírico. A questão conceitual é relativa à identificação do tipo de vínculo que se estabelece em torno dos incentivos presentes na área parlamentar, em contraposição àqueles presentes na arena eleitoral. De modo que, contrapondo-se à primeira abordagem, vários estudos começaram a resgatar o papel dos partidos políticos, o desempenho das lideranças e o peso relativo das regras decisórias internas do Congresso como variáveis a serem levadas em conta no exame do processo decisório (...). ${ }^{94}$

Assim, embora não haja consenso doutrinário acerca da adoção de políticas de tal natureza pelo legislador brasileiro, resta claro que a atuação parlamentar, especialmente em matéria orçamentária, procura efetivamente beneficiar Municípios da base eleitoral do parlamentar. A prática não é vedada pela legislação. Ao contrário, ante a ausência de definição de critérios para a alocação de recursos voltados às transferências voluntárias, a lacuna legislativa abre espaço aos projetos desta natureza. A quase totalidade das emendas parlamentares tenta garantir a destinação de recursos para as bases territoriais dos próprios políticos, propiciando, em tese, retornos eleitorais. No entanto, é possível entender também que o direcionamento se justifica pelo maior conhecimento da realidade das próprias bases eleitorais e suas respectivas necessidades.

Resta salientar que não obstante alguns autores façam referência às políticas pork barrel em seu aspecto negativo, ${ }^{95}$ enquanto medida voltada unicamente ao

votes, earn the backing of local interests, and gain financial support for reelection." (MCCAIN, John. McCain 4, 2003 apud PIRES JÚNIOR, José Antônio Meyer. Emendas orçamentárias individuais: "Pork Barrel" brasileiros?. Revista da CGU, Brasília, ano 1, n. 1, p. 86-102, 2006, p. 87). Em tradução nossa: “'Pork barrel' é um termo utilizado para descrever projetos patrocinados (financiados) pelo governo que fornecem benefícios para um distrito congressista ou um estado particulares e que tem o efeito adicional de ajudar um oficial eleito a ganhar votos, angariar a cobertura dos interesses locais e ganhar suporte financeiro para reeleição".

RICCI, Paolo, cit., p. 2.

95 Nesse sentido, mencione-se trecho mencionado por Celina Souza: "Na literatura derivada da escolha racional, as emendas dos parlamentares recebem o rótulo de pork barrel, que é definido 
objetivo de retorno eleitoral, tal não significa que os objetivos visados não estejam também em consonância com o interesse público.

\subsection{POSICIONAMENTOS RELACIONADOS ÀS TRANSFERÊNCIAS VOLUNTÁRIAS EXTRAÍDOS DE DECISÕES DO TRIBUNAL DE CONTAS DA UNIÃO}

No estudo das transferências voluntárias, algumas recomendações do Tribunal de Contas da União efetuadas a órgãos do governo que visam, em última análise, ao aprimoramento do mecanismo envolvendo a realização de transferências voluntárias assumem grande importância. Tais posicionamentos são relevantes como forma de complementar a disciplina da matéria, bastante escassa em termos de regulamentação legal e infralegal.

Os enunciados aqui elencados foram elaborados pela Diretoria de Jurisprudência do Tribunal, não constituindo resumos oficiais dos julgados. ${ }^{96}$ Nesse passo, destacam-se as orientações apontadas nas seções seguintes.

por Shepsle e Bonchek (1997:2004) como 'a apropriação de recursos federais para projetos ineficientes que beneficiam os distritos específicos dos congressistas mas que pouco favorecem a nação como um todo.' Os autores afirmam que o incentivo para um parlamentar operar uma política de pork barrel está na oportunidade que ele passa a ter para cobrar votos na próxima eleição. Na lógica da teoria da escolha racional, o pork barrel gera o paradoxo da cooperação, já que provê unicamente a área ou região que recebe esses recursos, a expensas de todos os contribuintes." Em continuidade, prossegue a autora:

No entanto, essa visão sobre as conseqüências "perversas" do pork não é unânime na literatura. Muitos cientistas políticos, a exemplo de Elwood e Patashnik (1993), ressaltam o "outro lado" do pork, mostrando seu papel de facilitador das negociações entre Executivo e Legislativo nos EUA e suas vantagens para o próprio orçamento público por não criar despesas que geram direitos e se transformam em atividades permanentes (entitlements). Outros trabalhos mostram ainda que, nos EUA, a eficácia do pork para a reeleição dos congressistas é mais modesta do que interpretado pela mídia (Bickers e Stein, 1996). Ademais, no caso brasileiro, emendas individuais foram, ao longo do tempo, sendo substituídas por coletivas, como se verá adiante" (SOUZA, Celina. Federalismo e Conflitos Distributivos: Disputa dos Estados por Recursos Orçamentários Federais. DADOS - Revista de Ciências Sociais, Rio de Janeiro, v. 46, n. 2, p. 345-384, 2003, p. 353).

96 Nesse sentido, informação extraída do próprio Portal do TCU na internet: "Essa pesquisa se dá em enunciados elaborados pela Diretoria de Jurisprudência da Secretaria das Sessóes do TCU a partir de deliberações selecionadas sob o critério de relevância jurisprudencial, não constituindo resumos oficiais das decisões proferidas neste Tribunal". 


\subsubsection{Submissão das transferências voluntárias operacionalizadas por meio de emendas parlamentares aos mesmos procedimentos relativos às transferências voluntárias, inclusive mediante a celebração de convênios e análise prévia dos planos de trabalho}

Nesse sentido, destaca-se o seguinte enunciado:

Monitoramento. Convênio e congênere. Os convênios e ajustes congêneres vinculados a emendas parlamentares sujeitam-se às mesmas regras exigidas para as transferências voluntárias ordinárias, razão pela qual não prescindem de prévia e necessária aprovação dos respectivos projetos ou planos de trabalho pelo órgão responsável pela execução orçamentária e financeira da emenda parlamentar. Determinação. ${ }^{97}$

Trata o julgado de determinação ao Ministério da Saúde para que se abstenha de "firmar convênios ou instrumentos congêneres e de repassar recursos sem a prévia e necessária aprovação dos respectivos planos de trabalho ou projetos (...)”.

Nas razões de voto do Ministro relator, restou consignado que as emendas parlamentares:

(...) constituem-se em instrumentos inerentes ao regime democrático e são, em muitos casos, o único meio de se fazer com que o Estado supra os anseios e as necessidades da população com pouco ou mesmo nenhum acesso aos braços dos Governos Federal e Locais, população esta, via de regra, instalada em comunidades carentes, de difícil acesso e, não raramente, prejudicadas pela falta de hospitais equipados e de profissionais de saúde especializados (...).

Em conclusão, aduziu o Relator:

Para tanto, julgo pertinente e oportuno incluir à proposta formulada pela unidade técnica determinação dirigida ao Ministério da Saúde para que, no âmbito dos convênios e demais ajustes vinculados a emendas parlamentares, mantenha os mesmos requisitos exigidos das demais transferências voluntárias previamente à liberação dos valores pactuados e por ocasião da prestação de contas, abstendo-se, por exemplo, de firmar convênios ou instrumentos similares e de repassar recursos sem a prévia e necessária aprovação dos respectivos planos de trabalho ou projetos.

Ainda no tocante às emendas parlamentares, outros enunciados relacionados ao tema das transferências voluntárias podem ser destacados:

Ainda que os recursos sejam provenientes de emendas parlamentares, o órgão concedente deve proceder a análises pormenorizadas da viabilidade técnica e econômica

97 BRASIL. Tribunal de Contas da União. Acórdão 2754-40/14-Plenário. Processo n. 012.075/2014-0. Relator: Ministro Aroldo Cedraz. Brasília, 15 out. 2014. Diário Oficial da Uniāo, Brasília, 5 nov. 2014. 
dos projetos propostos e efetuar o exame da capacidade técnica e operacional da entidade convenente para executar o objeto a ser pactuado, de modo a assegurar a alocação eficiente e efetiva dos recursos orçamentários. ${ }^{98}$

Em se tratando de Planos Setoriais de Qualificação decorrentes de emendas parlamentares, embora já venham com a indicação do convenente, deve o órgão concedente efetuar o exame da capacidade técnica e operacional da entidade executora. ${ }^{99}$

A expressa indicação, em emenda parlamentar, da entidade com quem deve ser firmado o convênio, não afasta a obrigação de o gestor verificar a sua qualificação técnica e operacional, bem como os demais requisitos previstos nas normas que regem a matéria, em especial o Decreto 6.170/2007 e a Portaria Interministerial MPOG/MF/CGU 507/2011. ${ }^{100}$

Dessa forma, ainda que as transferências decorram da execução de emendas parlamentares, com expressa previsão da entidade beneficiária, não se dispensa a aferição da qualificação técnica do ente nem dos aspectos relacionados ao plano de trabalho. Nesse sentido, o posicionamento vai de encontro à disciplina veiculada pela Emenda Constitucional n. 86/2015, no que prevê entre as hipóteses de exceção à execução obrigatória das emendas parlamentares a existência de impedimentos de ordem técnica.

\subsubsection{Observância da necessidade de aprovação dos planos de trabalho previamente à assinatura dos respectivos contratos de repasse: o controle preventivo pelos órgãos repassadores}

Em sentido semelhante, mencione-se acórdão relatado pelo Ministro Benjamin Zymler, no qual restou determinado à Caixa Econômica Federal que se abstivesse de firmar contratos de repasse antes da análise e aprovação dos planos de trabalho pelo órgão repassador, a fim de cumprir o estabelecido pelo artigo $2^{\circ} \mathrm{da}$ Instrução Normativa n. 1/97. A decisão se deu nos seguintes termos: "Auditoria. Convênio e congênere. Os contratos de repasse somente devem ser firmados após análise e aprovação dos planos de trabalho. Determinação". ${ }^{101}$

98 BRASIL. Tribunal de Contas da União. Acórdão 591-10/15-Plenário. Processo n. 005.313/2011-2. Relator: Ministro Marcos Bemquerer. Brasília, 25 mar. 2015. Diário Oficial da União, Brasília, 30 mar. 2015. Grifo nosso.

99 BRASIL. Tribunal de Contas da União. Grifo nosso.

100 BRASIL. Tribunal de Contas da União. Acórdão 2.871-42/14-Plenário. Processo n. 005.361/2011-

7. Relator: Ministro José Jorge. Brasília, 29 out. 2014. Diário Oficial da União, Brasília, 6 nov. 2014. Grifo nosso.

101 BRASIL. Tribunal de Contas da União. Acórdão 219-07/07-Plenário. Processo n. 025.175/2006-6. Relator: Ministro Benjamin Zymler. Brasília, 28 fev. 2007. Diário Oficial da União, Brasília, [2007?]. 
A determinação resultou da constatação, efetuada em auditoria pelo TCU, da ocorrência de vários casos em que o contrato de repasse foi assinado antes da aprovação do plano de trabalho, tendo-se concluído que:

(...) a apresentação prévia do Plano de Trabalho é condição sine qua non para que o convênio (contrato de repasse) venha a ser celebrado, haja vista que nele (PT) deverão estar, obrigatoriamente, demonstrados os custos e as quantidades necessários para atingimento do(s) objeto(s) pactuado(s).

A esse propósito, observa-se que a Portaria Interministerial n. 507/2011 foi expressa ao prever a aprovação do plano de trabalho como condição prévia à celebração do convênio:

Art. 39. Sem prejuízo do disposto nos art. 38 desta Portaria, são condições para a celebração de convênios:

I - cadastro do convenente atualizado no SICONV - Portal de Convênios no momento da celebração, nos termos dos arts. 19 a 21 desta Portaria;

II - Plano de Trabalho aprovado;

III - licença ambiental prévia, quando o convênio envolver obras, instalações ou serviços que exijam estudos ambientais, na forma disciplinada pelo Conselho Nacional do Meio Ambiente - CONAMA; e

IV - comprovação do exercício pleno dos poderes inerentes à propriedade do imóvel, mediante certidão emitida pelo cartório de registro de imóveis competente, quando o convênio tiver por objeto a execução de obras ou benfeitorias no imóvel; (...) (Grifo nosso)

Outro enunciado que revela a responsabilidade do órgão repassador não apenas no tocante à apreciação jurídica dos planos de trabalho e termos de convênios, mas também na avaliação técnica diretamente relacionada ao projeto, ressalta a necessidade de um controle preventivo pelos órgãos repassadores dos recursos: "É responsabilidade do órgão repassador dos recursos a realização de análises detalhadas de custo dos objetos propostos e da capacidade operacional das entidades proponentes para execução do objeto". ${ }^{102}$

Percebe-se, assim, pela dicção dos enunciados, a preocupação com o papel de controle a ser exercido pelo órgão arrecadador, especialmente sob o aspecto preventivo, competindo-lhe a verificação quanto ao custo do objeto proposto e à capacidade operacional do proponente, além de minuciosa análise dos planos de trabalho.

102 BRASIL. Tribunal de Contas da União. Acórdão 1933-39/07-Plenário. Processo n. 025.376/2006-4. Relator: Ministro Valmir Campelo. Brasília, 19 set. 2007. Diário Oficial da União, Brasília, 21 set. 2007. Grifo nosso. 


\subsubsection{Exceções à sanção de suspensão das transferências voluntárias: a área de atuação do meio ambiente}

Sob esse tópico, analisa-se o seguinte enunciado:

As exceções à sanção de suspensão de transferências voluntárias para entes federados inadimplentes (art. 25, $\$ 3^{\circ}$, da LRF) não abrangem, em regra, as áreas de atuação do Ministério do Meio Ambiente no âmbito do saneamento básico. Contudo, podem enquadrar-se naquelas exceções as ações desenvolvidas no âmbito da gestão de recursos hídricos e do manejo de resíduos sólidos, desde que tais açôes estejam expressamente descritas nos planos de saúde destinados à aplicação de recursos mínimos com ações e serviços públicos de saúde pelos entes federados (LC 141/2012). As disposiçôes do art. 26 da Lei n. 10.522/2002 (Cadin) não podem prevalecer ante ao que dispõe a Lei de Responsabilidade Fiscal, pois incumbe a esta dispor sobre finanças públicas. Assim, consoante o art. 25, $\$ 3^{\circ}$, da LRF c/c o art. 26 da Lei n. 10.522/2002, há autorização excepcional de transferência de recursos federais destinados à execução de ações sociais e açôes em faixa de fronteira para entes com registro no Cadin, inadimplentes em relação a transferências voluntárias, no que se refere, exclusivamente, à implementação de ações de educação, saúde e assistência social. ${ }^{103}$

Assim estabelece o mencionado artigo 26 da Lei Federal n. 10.522, de 19 de julho de 2002, que dispõe sobre o Cadastro Informativo dos Créditos não Quitados de Órgãos e Entidades Federais e dá outras providências:

Art. 26. Fica suspensa a restrição para transferência de recursos federais a Estados, Distrito Federal e Municípios destinados à execução de ações sociais ou ações em faixa de fronteira, em decorrência de inadimplementos objetos de registro no Cadin e no Sistema Integrado de Administração Financeira do Governo Federal - SIAFI.

Por seu turno, o artigo 25 da Lei de Responsabilidade Fiscal não excepciona, ao dispor sobre a suspensão das transferências voluntárias, outras ações, senão aquelas relativas à educação, saúde e assistência social, consoante dispõe seu $₫ 3^{\circ}$ :

Art. 25. Para efeito desta Lei Complementar, entende-se por transferência voluntária a entrega de recursos correntes ou de capital a outro ente da Federação, a título de cooperação, auxílio ou assistência financeira, que não decorra de determinação constitucional, legal ou os destinados ao Sistema Único de Saúde.

(...)

103 BRASIL. Tribunal de Contas da União. Acórdão 2329-34/14-Plenário. Processo n. 018.498/2013-2. Relator: Ministro Marcos Bemquerer. Brasília, 3 set. 2014. Diário Oficial da União, Brasília, 9 set. 2014. 
$\$ 3^{\circ}$ Para fins da aplicação das sanções de suspensão de transferências voluntárias constantes desta Lei Complementar, excetuam-se aquelas relativas a açóes de educação, saúde e assistência social. (Grifo nosso)

Assim, a medida encontrada pelo TCU decorre da interpretação sistemática dos dispositivos, abrangendo as ações relacionadas ao meio ambiente, desde que voltadas às finalidades protegidas pelo disposto na Lei de Responsabilidade Fiscal, isto é, relativas a ações de educação, saúde e assistência social.

\subsubsection{Necessidade de aparato e estrutura administrativa mínima para a celebração de ajustes envolvendo transferências voluntárias}

Nesse sentido, mencione-se o seguinte enunciado do TCU:

Entre as condições para celebração de transferências voluntárias deve constar a existência de setor específico com atribuições definidas para gestão (celebração, execução e prestação de contas) dos ajustes celebrados com a União, com lotação, ao menos, de um servidor efetivo. ${ }^{104}$

Mencionado enunciado resultou de levantamento efetuado pelo TCU, no qual restou demonstrado o elevado índice de inexecuções do volume de recursos transferidos, em virtude da inaptidão administrativa para a consecução do ajuste. Nesse sentido, transcreve-se excerto do voto do Ministro relator:

Conforme identificado pela Secex/RR, a União repassou, via transferências voluntárias, entre 2003 e 2012, recursos na ordem de $\mathrm{R} \$ 1.265 .297 .012,25$, que, comparativamente, correspondem a mais da metade do total de recursos próprios geridos pelos Municípios roraimenses. Todavia, do montante disponibilizado, 30,71\% não foram efetivamente utilizados, por motivos diversos, dentre os quais a ausência de estrutura administrativa capaz de efetivar o ajuste estabelecido e a fragilidade dos sistemas de controles internos administrativos municipais.

Nesse ponto, ainda, é oportuno apresentar, a título de sugestão, a inclusão de tópico específico a ser demonstrado pelos entes federados no tocante ao índice de inexecução dos recursos recebidos, visando a conferir ampla transparência ao referido número. A medida se mostra relevante e viria em boa hora, como uma forma de reconhecer eventuais entraves ao uso dos recursos, propiciando uma melhor distribuição e efetividade em sua aplicação.

104 BRASIL. Tribunal de Contas da União. Acórdão 568-07/14-Plenário. Processo n. 018.571/2013-1. Relator: Ministro Marcos Bemquerer. Brasília, 12 mar. 2014. Diário Oficial da União, Brasília, [mar. 2014?]. 


\subsubsection{Elementos para a caracterização da transferência como obrigatória ou voluntária}

Consoante já apontado, a simples previsão da transferência em lei não a torna automaticamente uma transferência obrigatória. Assim, ainda que esteja prevista em lei, se houver a previsão de atendimento a requisitos exigidos pelo órgão concedente, a transferência passa a dispor de natureza voluntária. Nesse sentido, destaca-se o seguinte enunciado:

Os aportes federais de recursos para educação por meio do Programa Nacional de Alimentação Escolar (Pnae) consistem em transferências voluntárias, pois são recursos transferidos a título de cooperação e mediante o atendimento de requisitos impostos pelo ente concedente. São recursos federais e não se tornam receita própria do ente beneficiário. Cabe à União a definição das regras gerais de aplicação dos recursos do Programa. Os estados e Municípios ditam apenas normas específicas. ${ }^{105}$ (Grifo nosso)

Desponta, nesse aspecto, outra sugestão para a divulgação transparente dos dados relacionados à publicidade desses repasses de recursos, consistente na definição de transferências voluntárias como aquelas que exigem o atendimento de requisitos por parte do convenente.

\subsubsection{Necessidade de aplicação dos recursos repassados por meio de transferências voluntárias enquanto não utilizados, ainda que o repasse seja feito automaticamente}

Sob esse tópico, analisa-se o seguinte enunciado: "Enquanto não utilizados, os recursos do PNAE devem ser aplicados no mercado financeiro". ${ }^{106}$ No mesmo sentido, em atenção à necessidade de aplicação dos recursos financeiros em decorrência do reconhecimento da natureza de transferência voluntária dos recursos transferidos para a execução do mencionado programa, veja-se o enunciado a seguir:

Os recursos financeiros transferidos para a execução do PNAE, enquanto não empregados em sua finalidade, devem ser aplicados em cadernetas de poupança, em fundos

105 BRASIL. Tribunal de Contas da União. Acórdão 2368-34/13-Plenário. Processo n. 035.358/2012-2. Relator: Ministro Benjamin Zymler. Brasília, 4 set. 2013. Diário Oficial da União, Brasília, 13 set. 2013.

106 BRASIL. Tribunal de Contas da União. Acórdão 5593-26/12-Segunda Câmara. Processo n. 037.018/2011-6. Relator: Ministro Raimundo Carreiro. Brasília, 31 jul. 2012. Diário Oficial da União, Brasília, 7 ago. 2012. 
de aplicação financeira de curto prazo ou em operação de mercado aberto, conforme disposições regulamentares da matéria. ${ }^{107}$

Salienta-se a importância dos enunciados, haja vista que os recursos do PNAE, conforme acima mencionado, têm sua transferência operacionalizada automaticamente, o que por si só não o descaracteriza enquanto espécie de transferência voluntária. Nessa medida, devem obediência às mesmas regras incidentes sobre as demais modalidades, como os recursos repassados por meio de convênios ou contratos de repasse, entre as quais a aplicação dos recursos enquanto não empregados em sua finalidade última.

\subsubsection{Necessidade de verificação da titularidade dos imóveis em que se desenvolverá o objeto relativo às transferências voluntárias}

Sob esse tópico, analisa-se o seguinte enunciado: "Em transferências voluntárias, a Administração Federal deve verificar a titularidade dos terrenos necessários à consecução do objeto sendo a confirmação da regularidade dessa questão condição indispensável para a assinatura do instrumento." ${ }^{108}$

O enunciado evidencia a responsabilidade imposta ao concedente relativamente à verificação da regularidade do ente convenente. Além de todos os requisitos relacionados à regularidade fiscal e financeira, a ele cabe, inclusive, a constatação da titularidade dos terrenos onde serão realizadas obras de engenharia com o emprego dos recursos transferidos. Ainda sobre a questão, destacam-se os enunciados a seguir:

A Administração somente deve emitir autorização para início das obras após a efetiva comprovação da titularidade das respectivas áreas, não admitindo para esse fim documentos diversos daqueles constantes em normas específicas. ${ }^{109}$

107 BRASIL. Tribunal de Contas da União. Acórdão 5292-32/10-Segunda Câmara. Processo n. 029.115/2007-4. Relator: Ministro Raimundo Carreiro. Brasília, 14 set. 2010. Diário Oficial da União, Brasília, 21 set. 2010.

108 BRASIL. Tribunal de Contas da Uniāo. Acórdão 3273-49/12-Plenário. Processo n. 006.250/2002-7. Relator: Ministro Augusto Sherman. Brasília, 28 nov. 2012. Diário Oficial da Uniāo, Brasília, [dez. 2012?].

109 BRASIL. Tribunal de Contas da União. Acórdão 1681-23/14-Plenário. Processo n. 000.278/2010-6. Relator: Ministro Marcos Bemquerer. Brasília, 25 jun. 2014. Diário Oficial da União, Brasília, 3 jul. 2014. 
O convenente deve comprovar a propriedade do imóvel em que o objeto será executado, cabendo ao concedente verificar o cumprimento dessa obrigação antes de assinar convênio, sob pena de responsabilização e multa. ${ }^{110}$

A apresentação de escritura pública de doação de imóvel pode suprir a comprovação da sua titularidade, exigível quando da celebração de convênio. ${ }^{111}$

Para a realização de serviços de reforma e ampliação de imóveis, são necessárias a obtenção de alvará de construção e a comprovação de propriedade dos imóveis onde serão realizadas as obras objeto da contratação. ${ }^{112}$

Nesse sentido, a exigência passou a ser incorporada pela Portaria Interministerial n. 507/2011, que impôs ao convenente a necessidade de comprovação da titularidade do imóvel onde será executado o objeto do ajuste, consoante dispóem especialmente os artigos $6^{\circ}$, inciso III, e 13 da mencionada Portaria, in verbis:

Art. 6o Ao convenente compete:

(...)

III - elaborar os projetos técnicos relacionados ao objeto pactuado, reunir toda documentação jurídica e institucional necessária à celebração do convênio, de acordo com os normativos do programa, bem como apresentar documentos de titularidade dominial da área de intervenção, licenças e aprovaçôes de projetos emitidos pelo órgão ambiental competente, órgão ou entidade da esfera municipal, estadual, do Distrito Federal ou federal e concessionárias de serviços públicos, conforme o caso, e nos termos da legislação aplicável; (...)

Art. 39. Sem prejuízo do disposto nos art. 38 desta Portaria, são condições para a celebração de convênios:

(...)

IV - comprovação do exercício pleno dos poderes inerentes à propriedade do imóvel, mediante certidão emitida pelo cartório de registro de imóveis competente, quando o convênio tiver por objeto a execução de obras ou benfeitorias no imóvel. (Grifo nosso)

110 BRASIL. Tribunal de Contas da União. Acórdão 6073-36/10-Segunda Câmara. Processo n. 030.802/2007-7. Relator: Ministro Augusto Sherman. Brasília, 19 out. 2010. Diário Oficial da União, Brasília, [out. 2010?].

111 BRASIL. Tribunal de Contas da União. Acórdão 414-03/10-Segunda Câmara. Processo n. 010.897/2007-3. Relator: Ministro Augusto Sherman. Brasília, 9 fev. 2010. Diário Oficial da Uniāo, Brasília, [fev. 2010?].

112 BRASIL. Tribunal de Contas da União. Acórdão 1.726-33/08-Plenário. Processo n. 007.831/2005-3. Relator: Ministro Augusto Sherman. Brasília, 20 ago. 2008. Diário Oficial da União, Brasília, [set. 2008?]. 


\subsubsection{Possibilidade de suspensão da inadimplência do ente federado, viabilizando o recebimento de recursos por meio de transferências voluntárias da União, desde que o ente esteja sendo administrado por outro gestor e tenham sido adotadas as providências pertinentes à apuração dos fatos}

Nesse sentido, mencione-se o seguinte enunciado do TCU:

Na hipótese de o Município estar sendo administrado por outro gestor, que não o faltoso, e comprovada a adoção das medidas pertinentes com vistas a apuração dos fatos, poderá ser suspensa a inadimplência daquele convenente, a fim de que possa receber novas transferências voluntárias. ${ }^{113}$

O enunciado vai de encontro à previsão inserta no artigo 72 da Portaria Interministerial n. 507/2011, especialmente em seu $\$ 8^{\circ}$, segundo o qual:

Art. 72. O órgão ou entidade que receber recursos na forma estabelecida nesta Portaria estará sujeito a prestar contas da sua boa e regular aplicação, observando-se o seguinte:

I - o prazo para apresentação das prestações de contas será de ate 60 (sessenta) dias após o encerramento da vigência ou a conclusão da execução do objeto, o que ocorrer primeiro; e

II - o prazo mencionado na alínea anterior constará no convênio.

$\llbracket 1^{\circ}$ Quando a prestação de contas não for encaminhada no prazo estabelecido no convênio, o concedente estabelecerá o prazo máximo de 30 (trinta) dias para sua apresentação, ou recolhimento dos recursos, incluídos os rendimentos da aplicação no mercado financeiro, atualizados monetariamente e acrescidos de juros de mora, na forma da lei.

$\$ 2^{\circ}$ Para os convênios em que não tenha havido qualquer execução física, nem utilização dos recursos, o recolhimento â conta única do Tesouro deverá ocorrer sem a incidência dos juros de mora.

$\$ 3^{\circ} \mathrm{Se}$, ao término do prazo estabelecido, o convenente não apresentar a prestação de contas nem devolver os recursos nos termos do $\$ 1^{\circ}$, o concedente registrará a inadimplência no SICONV por omissão do dever de prestar contas e comunicará o fato ao órgão de contabilidade analítica a que estiver vinculado, para fins de instauração de tomada de contas especial sob aquele argumento e adoção de outras medidas para reparação do dano ao erário, sob pena de responsabilização solidária.

$\$ 4^{\circ}$ Cabe ao prefeito e ao governador sucessor prestar contas dos recursos provenientes de convênios firmados pelos seus antecessores.

113 BRASIL. Tribunal de Contas da União. Acórdão 3034-53/09-Plenário. Processo n. 016.579/2009-2. Relator: Ministro Benjamin Zymler. Brasília, 9 dez. 2009. Diário Oficial da União, Brasília, 11 dez. 2009. 
$\$ 5^{\circ} \mathrm{Na}$ impossibilidade de atender ao disposto no parágrafo anterior, deverá apresentar ao concedente justificativas que demonstrem o impedimento de prestar contas e as medidas adotadas para o resguardo do patrimônio público.

\$ 60 Quando a impossibilidade de prestar contas decorrer de ação ou omissão do antecessor, o novo administrador solicitará ao concedente a instauração de tomada de contas especial.

$\$ 7^{\circ}$ Os documentos que contenham as justificativas e medidas adotadas serão inseridos no SICONV.

$\$ 8^{\circ}$ No caso do convenente ser órgão ou entidade pública, de qualquer esfera de governo, a autoridade competente, ao ser comunicada das medidas adotadas, suspenderá de imediato o registro da inadimplência, desde que o administrador seja outro que não o faltoso, e seja atendido o disposto nos $\$ \$ 5^{\circ}, 6^{\circ}$ e $7^{\circ}$ deste artigo.

$\$ 9^{\circ}$ Os convenentes deverão ser notificados previamente sobre as irregularidades apontadas, via notificação eletrônica por meio do SICONV, devendo ser incluída no aviso a respectiva Secretaria da Fazenda ou secretaria similar.

\$10 Enquanto não disponível a notificação eletrônica, a notificação prévia será feita por meio de carta registrada com declaração de conteúdo, com cópia para a respectiva Secretaria da Fazenda ou secretaria similar, devendo a notificação ser registrada no SICONV.

$\$ 11$ O registro da inadimplência no SICONV só será efetivado 45 (quarenta e cinco) dias após a notificação prévia. (Grifo nosso)

Nesse contexto, destaca-se que o ente concedente figura como o órgão responsável pela inclusão e exclusão dos entes faltosos no cadastro de inadimplentes, impondo-lhes assim as consequências restritivas, especialmente quanto ao recebimento de novas transferências voluntárias. A esse propósito, destacam-se os seguintes enunciados:

Compete ao órgão concedente proceder à inscrição e, se for o caso, registrar a suspensão da inadimplência no SIAFI. No caso de a entidade ter outro administrador que não o faltoso, o novo gestor deve comunicar ao concedente as providências adotadas com vistas ao ressarcimento ao erário e comprovar, semestralmente, o prosseguimento das ações adotadas, sob pena de retorno à situação de inadimplência. ${ }^{114}$

A competência para efetuar lançamentos de inclusão, exclusão e atualização de dados nos cadastros restritivos, como o Siafi e o Siconv, é do concedente, responsável pela transferência dos recursos públicos federais. ${ }^{115}$

114 BRASIL. Tribunal de Contas da União. Acórdão 2184-12/13-Segunda Câmara. Processo n. 003.172/2013-9. Relatora: Ministra Ana Arraes. Brasília, 23 abr. 2013. Diário Oficial da União, Brasília, 26 abr. 2013.

115 BRASIL. Tribunal de Contas da União. Acórdão 2179-40/08-Plenário. Processo n. 019.596/2008-9. Relator: Ministro Marcos Bemquerer. Brasília, 1o out. 2008. Diário Oficial da União, Brasília, [out. 2008?]. 
A baixa da inadimplência e da responsabilidade do gestor faltoso só pode ser dada após a comprovação do recolhimento do débito perante o TCU, que, por sua vez, expedirá quitação ao responsável, após o devido pagamento. ${ }^{116}$

\subsubsection{Quanto à vedação de utilização das transferências voluntárias para pagamento de despesas com pessoal}

Os enunciados do presente tópico constituem decorrência do disposto no inciso X do artigo 167 da Constituição Federal, que veda a transferência voluntária de recursos para pagamento de despesas com pessoal ativo, inativo e pensionista, dos Estados, do Distrito Federal e dos Municípios, abarcando também os serviços terceirizados. Nas palavras do TCU:

É vedada a transferência voluntária de recursos para pagamento de pessoal de entes federados, inclusive se os repasses forem utilizados para pagamento de terceirização de mão de obra no exercício de atividades finalísticas do órgão em substituição ao servidor público. ${ }^{117}$

O Fundo Nacional de Desenvolvimento da Educação (FNDE) não deve efetuar suplementação financeira a estados e Municípios para o custeio de contratação temporária ou permanente de profissionais de educação básica, na modalidade de transferência voluntária de recursos, por afrontar o inciso X do art. 167 da Constituição Federal, c/c o art. 18, $\$ 1^{\circ}$, da Lei Complementar n. 101/2000 (LRF), e art. 22, parágrafo único, incisos II e III, da Lei n. 11.494/2007. ${ }^{118}$

\subsection{PRINCIPAIS VICISSITUDES DO SISTEMA DE TRANSFERÊNCIAS VOLUNTÁRIAS E SUGESTÕES RELACIONADAS À MELHORIA DAS DEFICIÊNCIAS APONTADAS}

Entre os diversos problemas destacados que atingem as transferências voluntárias encontram-se a ineficiência, o desvio de recursos públicos, a falta de prestação de contas, assim como a ausência de suporte administrativo adequado. Consoante

116 BRASIL. Tribunal de Contas da Uniāo. Acórdão 331-06/08-Plenário. Processo n. 250.047/1998-5. Relator: Ministro Augusto Nardes. Brasília, 5 mar. 2008. Diário Oficial da União, Brasília, [mar. 2008?].

117 BRASIL. Tribunal de Contas da União. Acórdão 3294-54/11-Plenário. Processo n. 010.935/2011-8. Relator: Ministro Marcos Bemquerer. Brasília, 7 dez. 2011. Diário Oficial da Uniāo, Brasília, 15 dez. 2011.

118 BRASIL. Tribunal de Contas da União. Acórdão 2870-40/10-Plenário. Processo n. 023.857/2008-3. Relator: Ministro José Jorge. Brasília, 27 out. 2010. Diário Oficial da Uniāo, Brasília, $1^{\circ}$ nov. 2010. 
aponta Romiro Ribeiro, constitui abordagem superficial creditar à má gestão dos recursos por parte dos órgãos repassadores e à falta de qualificação da mão de obra no serviço público, além da deficiente estrutura técnica e de pessoal, os problemas verificados nas transferências voluntárias. ${ }^{119}$ Existem outras dificuldades relacionadas à temática das transferências voluntárias, além daquelas inicialmente mencionadas, entre as quais:

a) exclusão dos recursos destinados aos convênios formalizados pelo Ministério da Saúde das estatísticas de transferências voluntárias: segundo o autor, haveria um equívoco na metodologia empregada, tendo em vista que todos os recursos destinados à programação do Ministério da Saúde estariam sendo excluídos, e não apenas aqueles destinados ao SUS;

b) exclusão (omissão) do valor dos restos a pagar: isso comprometeria a realidade dos dados, pelo fato de que expressivo percentual dos recursos destinados aos estados e Municípios são empenhados nos últimos 60 dias do exercício;

c) características básicas do modelo legal de transferências voluntárias, que refletem a complexidade do processo: tais características - consistentes, basicamente no: i) formalismo processual (extenso rol de documentos exigidos para a formalização do convênio), no ii) personalismo na análise das transferências (observância de critérios subjetivos), e na iii) descentralização tutelada (monitoramento do ente beneficiário que age em nome próprio pelo ente repassador, a quem compete um amplo espectro de atribuições, desde o planejamento até a prestação de contas) -, conduzem à ineficiência, à pulverização de recursos e à falsa descentralização, criando condições propícias à atuação dolosa de agentes públicos e privados;

d) deficiência de controle dos órgãos repassadores: constituiria a principal irregularidade, dando ensejo à existência de planos de trabalho e projetos mal elaborados, análises técnicas superficiais, deficiência no acompanhamento da execução do projeto e da respectiva prestação de contas. Segundo o diagnóstico do autor, não há estrutura da União para analisar e fiscalizar os cerca de 24 mil convênios celebrados anualmente. Além disso, convênios de baixo valor movimentam grande aparato do Estado;

e) descompasso entre o planejado e o executado: a esse propósito, o autor cita o caso emblemático da análise de convênio celebrado entre o Fundo Nacional

119 RIBEIRO, Romiro. Orçamento público semi-impositivo para transferências voluntárias: diagnóstico, perspectivas e proposta de mudanças. E-Legis - Revista Eletrônica do Programa de Pós-Graduação da Câmara dos Deputados, Brasília, n. 4, p. 149-167, 2010. 
de Saúde e o Município de Mato Dentro, em Minas Gerais (Convênio n. 864/1994). Conforme aduz o autor:

(...) as verbas do citado Convênio, no valor de $\mathrm{R} \$ 19.450,36$, destinavam-se à aquisição e distribuição à população carente de 5.976 quilogramas de leite e 446 litros de óleo. Ao invés de cumprir este programa de trabalho o prefeito adquiriu 3.590,4 quilogramas de leite em pó e, com os recursos referentes à contrapartida municipal, comprou cestas básicas para distribuição à população carente, no valor de $\mathrm{R} \$$ $10.728,00 .^{120}$

O contrato foi julgado irregular pelo TCU em razão do desvio de finalidade. Com efeito, parece-nos assistir razão ao autor ao apontar a incongruência da decisão do Tribunal de Contas, levando em conta apenas a literalidade dos termos conveniados. Nessa medida, mesmo que a utilização dos recursos se desse em finalidade diversa ao objeto do convênio, eles foram empregados no atingimento de objetivos voltados ao combate à desnutrição, o que, de certa forma, não destoaria do programa de governo a ser atendido. A submissão a determinadas amarras formais conflita com princípios elementares que regem a atuação da Administração Pública, com especial destaque para os princípios da eficiência e da observância do interesse público.

Em outros julgados, contudo, o Tribunal de Contas da União considerou a destinação dos recursos em benefício da coletividade como critério para o afastamento da apenação aos responsáveis, ainda que verificada, em tese, a utilização dos recursos em desconformidade ao objeto conveniado:

15. Sobre isso, registro que este Tribunal, ao apreciar casos similares, tem decidido no sentido de que, não obstante os recursos públicos federais repassados terem sido utilizados em objeto diverso do conveniado, se não houver indícios de locupletamento por parte do gestor dos recursos e estes tiverem sido utilizados em benefício da comunidade local e da municipalidade, podem as contas serem julgadas regulares com ressalva. Confira-se, nessa linha, o Acórdão 27/2004-TCU-1ª Câmara.

16. No caso sob análise, como os recursos conveniados foram empregados em benefício da comunidade local, entendo não restar configurado dano ao erário. Outrossim, não identifico nos autos quaisquer indícios de locupletamento por parte do gestor dos recursos.

17. Portanto, considero que, no presente caso, em caráter excepcional, o débito levantado nos autos pode ser afastado, tendo em vista que a destinação dada aos recursos conveniados atingiu a finalidade social pretendida pelo convênio.

18. Por fim, no tocante à alteração promovida no plano de trabalho sem prévia autorização do órgão repassador, entendo que tal falha, embora caracterize infração à

${ }^{120}$ RIBEIRO, Romiro, cit., p. 158. 
norma legal de natureza financeira e patrimonial, não se reveste de gravidade suficiente a justificar a apenação do responsável. ${ }^{121}$

Surge, assim, à guisa de sugestão, a possibilidade de flexibilização dos objetivos conveniados e da análise da extensão dos danos ocasionados com a alteração do objeto. Não se trata de conferir total discricionariedade ao gestor para a definição do objeto do convênio, mas sim de permitir sua flexibilização diante da necessidade superveniente. Também se propõe a alteração de critérios burocráticos, voltados à regularidade da contratação e da prestação de contas, por meio da mitigação dos formalismos exacerbados, sem violação ao princípio da legalidade. O foco deve se voltar mais aos resultados, e não propriamente à observância de regras preestabelecidas, deixando-se assim o campo mais aberto;

f) descompasso entre os custos de execução e fiscalização do convênio e o valor do próprio convênio e constatação de deficiências dos órgãos federais em planejar, analisar e fiscalizar os recursos transferidos: como forma de contornar as falhas apontadas, sugere Romiro Ribeiro a incorporação dos recursos transferidos ao patrimônio dos entes beneficiários, competindo-lhes então a verificação da regularidade de sua aplicação. Eventuais irregularidades implicariam na devolução dos recursos recebidos, mediante retenção dos recursos do FPE e FPM. ${ }^{122}$ No entanto, a sugestão apresentada, ao restringir o controle ao ente beneficiário, poderá ensejar certa dose de protecionismo das estruturas internas do ente, tornando-o conivente com as práticas realizadas, em prol dos interesses da unidade federada.

121 BRASIL. Tribunal de Contas da União. Acórdão 1176-08/09-Primeira Câmara. Processo n. 017.950/2006-6. Relator: Ministro Augusto Nardes. Brasília, 24 mar. 2009. Diário Oficial da Uniāo, Brasília, 27 mar. 2009.

122 RIBEIRO, Romiro, cit., p. 161. 